\title{
THE NEWCASTLE GEOTHERMAL SYSTEM
} IRON COUNTY, UTAH

\author{
GEOLOGY, HYDROLOGY, AND CONCEPTUAL MODEL \\ VOLUME 1: FINAL REPORT
}

\author{
Prepared for: \\ The U.S. Department of Energy \\ Geothermal Technology Division \\ State Cooperative Geothermal Research \\ Grant Number: DE-FG07-88ID12756
}

Prepared by:

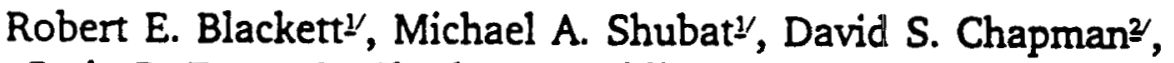
Craig B. Forster", Charles M. Schlinger², Charles E. Bishop” ${ }^{\prime \prime}$

March 1990

\footnotetext{
1/ Utah Department of Natural Resources Geological and Mineral Survey

2/ University of Utah

Department of Geology and Geophysics
} 


\section{NOTICE}

This report was prepared to document work sponsored by the United States Government. Neither the United States nor its agent, the United States Department of Energy, nor any Federal employees, nor any of their contractors, subcontractors or their employees, makes any warranty, express or implied, or assumes any legal liability or responsibility for the accuracy, completeness, or usefulness of any information, apparatus, product or process disclosed, or represents that its use would not infringe privately owned rights.

At the time of preparation, this report was not yet processed through the Utah Geological and Mineral Survey review and editorial system. Reference to a company or product name does not imply approval or recommendation of the product by the Utah Geological and Mineral Survey or the U.S. Department of Energy to the exclusion of others that may be suitable. 


\section{DISCLAIMER}

This report was prepared as an account of work sponsored by an agency of the United States Government. Neither the United States Government nor any agency Thereof, nor any of their employees, makes any warranty, express or implied, or assumes any legal liability or responsibility for the accuracy, completeness, or usefulness of any information, apparatus, product, or process disclosed, or represents that its use would not infringe privately owned rights. Reference herein to any specific commercial product, process, or service by trade name, trademark, manufacturer, or otherwise does not necessarily constitute or imply its endorsement, recommendation, or favoring by the United States Government or any agency thereof. The views and opinions of authors expressed herein do not necessarily state or reflect those of the United States Government or any agency thereof. 


\section{DISCLAIMER}

Portions of this document may be illegible in electronic image products. Images are produced from the best available original document. 


\section{TABLE OF CONTENTS}

ABSTRACT $\ldots \ldots \ldots \ldots \ldots \ldots \ldots \ldots \ldots \ldots \ldots \ldots \ldots \ldots \ldots \ldots \ldots \ldots$

EXECUTIVE SUMMARY $\ldots \ldots \ldots \ldots \ldots \ldots \ldots \ldots \ldots \ldots \ldots$ vii

ACKNOWLEDGMENTS $\ldots \ldots \ldots \ldots \ldots \ldots \ldots \ldots \ldots \ldots \ldots \ldots \ldots \ldots$ xiii

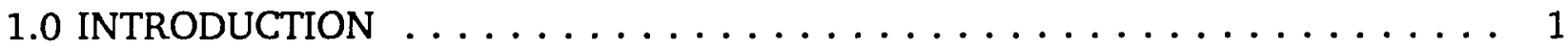

1.1 General Statement $\ldots \ldots \ldots \ldots \ldots \ldots \ldots \ldots \ldots \ldots \ldots \ldots$

1.2 Purpose and Scope . . . . . . . . . . . . . . . 1

1.3 Background and Previous Work ................ 2

1.4 Location and Regional Setting $\ldots \ldots \ldots \ldots \ldots \ldots \ldots$

2.0 GEOLOGIC INVESTIGATIONS $\ldots \ldots \ldots \ldots \ldots \ldots \ldots \ldots \ldots \ldots$

2.1 Mapping of Bedrock and Surficial Units $\ldots \ldots \ldots \ldots \ldots \ldots$

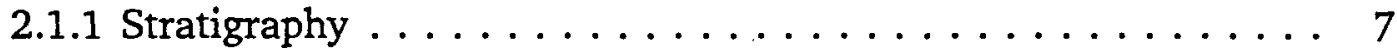

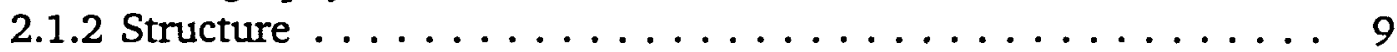

2.2 Fault Slip Analysis . . . . . . . . . . . . . . . 10

2.2.1 Map-scale Faults and the Fault Slip Analysis . . . . . . . 19

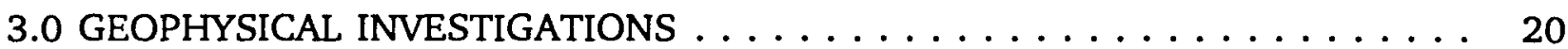

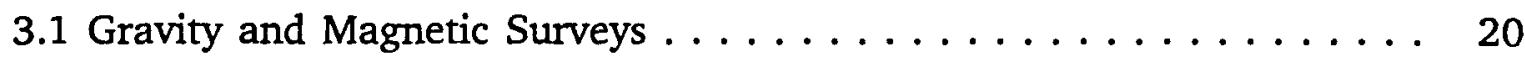

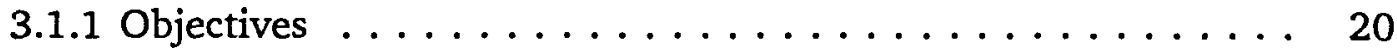

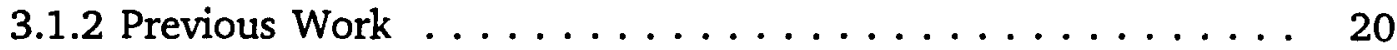

3.1.3 Magnetic Survey . . . . . . . . . . . . 20

3.1 .4 Gravity Survey . . . . . . . . . . . . . . . . 23

3.2 Resistivity and Spontaneous Potential (SP) Surveys $\ldots \ldots \ldots \ldots . \ldots 32$

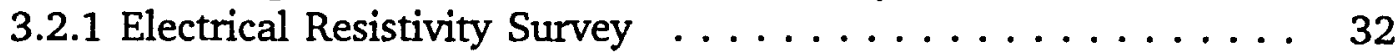

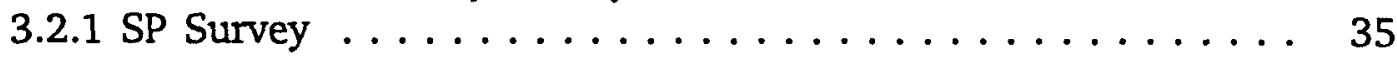

4.0 SOIL-GAS GEOCHEMICAL INVESTIGATIONS $\ldots \ldots \ldots \ldots \ldots \ldots \ldots \ldots$

4.1 Soil-Mercury Survey $\ldots \ldots \ldots \ldots \ldots \ldots \ldots \ldots \ldots \ldots \ldots \ldots$

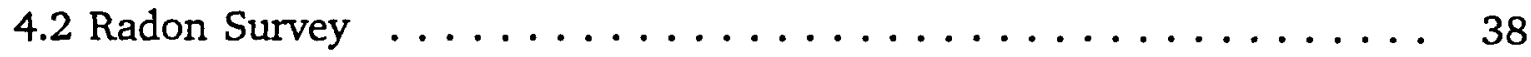

5.0 A CONCEPTUAL MODEL FOR FLUID FLOW AND HEAT

TRANSPORT IN THE NEWCASTLE GEOTHERMAL SYSTEM $\ldots \ldots 44$

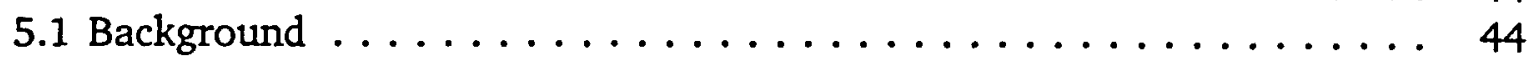

5.2 The Newcastle Geothermal Area . . . . . . . . . . . . . . . 46

5.3 Subsurface Temperature Field and Heat Flow Data . . . . . . . . 53

5.3.1 Temperature-depth results $\ldots \ldots \ldots \ldots \ldots \ldots \ldots \ldots$

5.3 .2 Heat flow map. . . . . . . . . . . . . 55 
TABLE OF CONTENTS (CONTINUED)

5.4 Hydrochemistry and Stable Isotopes . . . . . . . . . . . . . 59

5.4 .1 Common Ion Analyses . . . . . . . . . . . . . 61

5.4.2 Chemical Geothermometry ............... 61

5.4.3 Light Stable Isotope Analyses .............. 64

5.5 Hydrologic Interpretation of Geophysical Studies . . . . . . . 65

5.6 Numerical Modeling . . . . . . . . . . . . . . 66

5.6 .1 Modelling Approach $\ldots \ldots \ldots \ldots \ldots \ldots \ldots 67$

5.6.2 Model Parameterization ................. 69

5.6 .3 Modelling Results . . . . . . . . . . . . 70

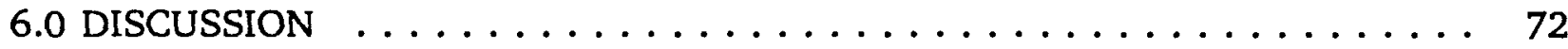

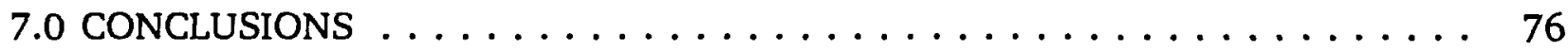

8.0 RECOMMENDATIONS $\ldots \ldots \ldots \ldots \ldots \ldots \ldots \ldots \ldots \ldots \ldots \ldots \ldots$

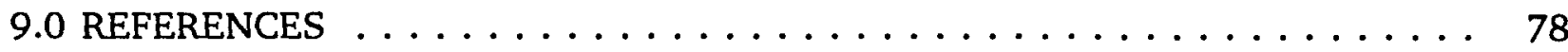

\section{APPENDICES}

APPENDIX A: $\quad$ Slip-vector data

APPENDIX B: $\quad$ Pascal program for slip-vector analysis

APPENDIX C: $\quad$ Gravity station location and elevation data

APPENDIX D: $\quad$ Gravity readings, meter number, time and date

APPENDIX E: Tabulated temperature-depth, thermal conductivity, and lithology data for thermal monitoring wells NC-14 through NC-27

APPENDIX F: $\quad$ Hydrochemistry -- sampling methods and analytical data 


\section{LIST OF FIGURES}

Figure 1. Location map. (3)

Figure 2. Map of the project area, major geothermal systems, and the Sevier thermal area. (4)

Figure 3. Physiographic and major structural features of southwestern Utah. (6)

Figure 4. Slip axes orientations, strike and dip of fault planes, and rake of slickensides for sites A, B, C, and D. $(11,12)$

Figure 5. Index map of the Newcastle geothermal area showing the location of fault slip data collection sites. (14)

Figure 6. Frequency histogram of principal axes misfit angles for site A. (17)

Figure 7. Lower hemisphere stereoplots showing the orientations of principal axes of solution tensors. (18)

Figure 8. Bouguer gravity anomaly map of southwestern Utah. (21)

Figure 9. Aeromagnetic map of southwestern Utah. (22)

Figure 10. Gravity survey station locations. (24)

Figure 11. Station locations, Bouguer gravity, and elevations along line SS. (25)

Figure 12. Station locations, Bouguer gravity, and elevations along line LL. (26)

Figure 13. Model of subsurface structure in the vicinity of Newcastle. (30)

Figure 14. Comparison between observed data and calculated gravity anomaly. (31)

Figure 15. Contoured apparent resistivity for $3^{\text {rd }}$ separation. (34)

Figure 16. Numerical model solution for resistivity line 2. (35)

Figure 17. Contour map of SP data. (36)

Figure 18. Soil-mercury sample locations, sample values, and areas of high mercury concentrations. (39) 


\section{LIST OF FIGURES (CONTINUED)}

Figure 19. Location of radon traverse lines, sample points, and radon concentrations. (41)

Figure 20. Profile of radon traverse lines 1, 2, and 3. (42)

Figure 21. Working model for the hydrothermal system at Newcastle. (45)

Figure 22. Temperature-Depth plots for wells NC-2 through 12. (46)

Figure 23. Well location map. (47)

Figure 24. Temperature-Depth log for Union Geothermal Christiansen \#1 Well (CHR-1). (48)

Figure 25. Heat flow map for the Newcastle geothermal system. (50)

Figure 26. Temperature of groundwater in the Beryl-Enterprise area. (51)

Figure 27. Helium concentrations in the Newcastle area. (52)

Figure 28. Composite temperature-depth plots -- this study. (54)

Figure 29. Revised heat flow map for the Newcastle geothermal system. (57)

Figure 30. Specific conductance of groundwater in the Beryl-Enterprise area. (60)

Figure 31. Piper diagram for water samples WS-1 through WS-6. (62)

Figure 32. Plot of $\delta \mathrm{D}$ versus $\delta^{18} \mathrm{O}$ showing the results of stable isotope analyses reported in Appendix F. (65)

Figure 33. Generalized boundary value problems. (68)

Figure 34. Updated conceptual model for patterns of groundwater flow in the Newcastle hydrothermal system. (72) 


\section{TABLES}

Table 1. Results of slip vector analysis. (16)

Table 2. Summary of temperature gradient, thermal conductivity, and heat flow data for the thermal monitoring wells NC-2 through NC-27. (56)

Table 3. Heat loss for the Newcastle geothermal system. (58)

Table 4. Results of chemical analyses of groundwater samples obtained near Newcastle, Utah. (59)

Table 5. Results of geothermometry calculations carried out using chemical analyses of groundwater samples obtained near Newcastle, Utah. (63)

Table 6. Results of light stable isotope analyses ( $\delta \mathrm{D}$ and $\delta^{18} \mathrm{O}$ expressed as per mil relative to V-SMOW) carried out on groundwater samples obtained from springs and wells near Newcastle, Utah. (64)

\section{PLATES}

Plate 1: Geologic map of the Newcastle geothermal area. (in pocket)

Plate 2: Geologic cross sections A-A', B-B', C-C'. (in pocket)

Plate 3: Union Geothermal Christiansen \#1 Well -- Temperature, lithology, and geophysical logs. (in pocket) 


\begin{abstract}
Geological, geophysical and geochemical studies contributed to a conceptual hydrologic model of the "blind" (no surface expression), moderate-temperature (greater than $130^{\circ} \mathrm{C}$ ) Newcastle geothermal system, located in the Basin and Range-Colorado Plateau transition zone of southwestern Utah. Temperature gradient measurements define a thermal anomaly centered near the surface trace of the range-bounding Antelope Range fault with an elongate dissipative plume extending north into the adjacent Escalante Valley. Spontaneous potential and resistivity surveys sharply define the geometry of the dominant upflow zone (not yet explored), indicating that most of the thermal fluid issues from a short segment along the Antelope Range fault and discharges into a gently-dipping aquifer. Production wells show that this aquifer lies at a depth between 85 and 95 meters. Electrical surveys also show that some leakage of thermal fluid occurs over a $1.5 \mathrm{~km}$ (minimum) interval along the trace of the Antelope Range fault. Major element, oxygen and hydrogen isotopic analyses of water samples indicate that the thermal fluid is a mixture of meteoric water derived from recharge areas in the Pine Valley Mountains and cold, shallow groundwater. A northwest-southeast trending system of faults, encompassing a zone of increased fracture permeability, collects meteoric water from the recharge area, allows circulation to a depth of 3 to 5 kilometers, and intersects the northeast-striking Antelope Range fault. We postulate that mineral precipitates form a seal along the Antelope Range fault, preventing the discharge of thermal fluids into basin-fill sediments at depth, and allowing heated fluid to approach the surface. Eventually, continued mineral deposition could result in the development of hot springs at the ground surface.
\end{abstract}




\section{Overview}

\section{EXECUTIVE SUMMARY}

The volcanic and tectonic setting of southwestern Utah provides a unique opportunity for studying hydrothermal systems. Within the region, widespread mid- to late-Tertiary rhyolitic and andesitic volcanic and intrusive rocks, invaded folded and thrusted Paleozoic and Mesozoic marine sedimentary rocks. Volcanic products of the recent geologic past include Quaternary rhyolitic domes and basaltic flows. Basin and Range tectonism, active over the past several million years, overprints this already complex setting with numerous, roughly north-south trending extensional faults and less obvious oblique fault and fracture zones. Two broad east-west trending belts of mineralization -- the Pioche-Marysvale and the Delamar-Iron Springs belts -- provide evidence of past hydrothermal activity in the region. The region is still undergoing active tectonism as evidenced by earthquakes generated within the Intermountain seismic belt and elevated regional heat flow. Physiography, reflective of the region's complex geologic past, comprises low-lying mountain ranges situated westward from the high plateaus of the Colorado Plateau-Basin and Range transition, surrounding broad, deep, sedimentfilled basins. Over the past 10 to 15 years, researchers have compiled abundant new geologic data on both local and regional scales within southwestern Utah, making possible better understanding of geologic and hydrologic controls of hydrothermal convection systems.

The region contains two of the nation's commercially significant geothermal fields - Roosevelt Hot Springs and Cove Fort-Sulphurdale KGRAs -- and a number of other systems that possess future geothermal development potential for binary electric and nonelectric applications. The Newcastle area, located on southeast edge of the Escalante Valley and the focus of our work, is particularly intriguing because it is a completely concealed hydrothermal system. No surface expression of hydrothermal activity -- hot springs, fumaroles, or alteration minerals -- exists. Water well drillers discovered the system in 1975 as result of pump-testing a newly drilled well. A temperature profile of the well depicted a geothermal aquifer at depths between 280 and 310 feet. Upon pumping, the well delivered water at temperatures near boiling. After discovery, geologists from the U.S. Geological Survey, and researchers at the University of Utah studied the system to a limited extent. Several private geothermal companies also studied the Newcastle area and drilled a number of exploratory wells. Presently, three commercial greenhouses, a Mormon church building, and various residences in Newcastle use the hot water for space heating.

Geoscientists have postulated that such "blind" hydrothermal systems exist and estimate that blind systems could contain several times more energy than that presently accessible in known hydrothermal systems. In an effort to characterize the Newcastle system, we augmented existing studies by performing more detailed geological, geophysical, and geochemical investigations, in order to formulate a conceptual model. 
Such a model might be useful as an analog for other undiscovered geothermal systems in the region. Moreover, the added resource information will help with better reservoir management as geothermal development continues at Newcastle.

\section{About the Project}

Our project consisted of several activities, or tasks, designed to characterize some aspect of the system, and lead to the development of a conceptual model. Primary project tasks consisted of:

1. geologic mapping of Quaternary valley-fill units

2. geologic mapping of bedrock units and structural analysis

3. acquisition and modelling of detailed gravity data

4. common ion and hydrogen/oxygen isotopic analysis of water samples from wells and springs

5. soil-mercury and radon surveys

6. shallow, temperature gradient drilling to better define the extent of the thermal plume, and

7. numerical and conceptual modeling of the hydrothermal system

Additional work included an electrical resistivity survey and a spontaneous potential (SP) survey performed by researchers from the Earth Science Laboratory, University of Utah Research Institute with assistance from UGMS staff geologists.

\section{Geologic Mapping}

Utah Geological and Mineral Survey (UGMS) geologists performed geologic mapping of surficial units in the Escalante Valley. Quaternary geologic units that comprise the valley fill generally terminate at the Antelope Range Fault, a major northnortheast trending, range-bounding normal fault that marks the southeast edge of the Escalante Valley. A smaller-scale normal fault faces opposite the Antelope Range fault and cross-cuts the valley fill a few thousand feet to the northwest. These two structures enclose a geologic feature termed the Newcastle graben, a subset of the Escalante Valley, indirectly observed through geophysical studies. Scarp morphology along the Antelope Range fault suggests a middle to late-Pleistocene age for the last surface-rupturing event. 
Geologic mapping of bedrock units within the northwest extension of the Pine Valley Mountains, performed by geologists from the UGMS and U.S. Geological Survey (USGS), provided many insights about the structural history of the area. Oligocene and Miocene ash-flow tuffs, debris flows, and rhyolite flows provide good stratigraphic markers for determining fault locations, displacements, and attitudes. Detailed mapping revealed a complex network of faults and fracture zones where the greatest stratigraphic separation (2,000 to 3,000 feet) occurs along northwest-striking faults and fault zones. Fracture density appears greater within a northwest-trending zone projecting through the geothermal area. Several map-scale bedrock faults within this zone, when projected onto the buried surface of the Antelope Range fault, coincide with the center of the thermal anomaly.

Fault slip studies involved the gathering of fault-slip data (strike, dip, rake, and sense of slip) from bedrock terrain at four sites in and around Newcastle. These data, input into computer software acquired from other researchers and modified for our work here, yielded results suggesting that two principal tectonic events are responsible for the fault and fracture systems seen in the study area. An older event occurred between 21 and 8.5 million years ago, associated with regional southwest-directed extension, and produced the northwest-trending zone of faults mapped in bedrock. A second event, active between 8.5 million years ago and the present, produced the Antelope Range fault and adjacent Newcastle graben. Of the faults produced during the older event, few were reactivated during the younger event. The younger event appears to have generated relatively few new faults away from the Antelope Range fault, contributing little to the bedrock permeability.

\section{Thermal Gradient and Heat Flow Investigations}

Scientists from the University of Utah, Department of Geology and Geophysics performed temperature monitoring within previously drilled holes and within holes drilled specifically for this project. Previous workers, because of a lack of survey control and a more complete data set, had mistakenly mapped the center of upflow for the geothermal system at a location displaced a few thousand feet away from the mountain front. Using the results of twelve new temperature gradient holes and better location/elevation control, University of Utah scientists accurately defined the location of the Newcastle temperature anomaly and constructed a new heat flow map. The results of this work indicate that the near surface thermal anomaly is spatially associated with a short segment of the Antelope Range fault.

\section{Geophysical Surveys}

Geophysical investigations at Newcastle included detailed gravity studies, a limited magnetic investigation which yielded little useful information due to interference with power transmission lines, a resistivity survey, and a spontaneous potential (SP) survey. 
We carried out the gravity and magnetic studies in an effort to define bedrock structures beneath the Escalante Valley sediments. Resistivity and SP studies, performed in cooperation with the University of Utah Research Institute, helped better determine the location of upflowing geothermal fluid and the dispersion of the outflow plume.

Gravity studies entailed two separate field investigations, performed by University of Utah scientists and students, whereby a total of 394 close-spaced gravity stations were occupied. After compiling and applying routine reductions to the data, numerical modeling (along with the results from surface geologic mapping) provided an interpretation of the subsurface geology. The interpretation depicts the northwest extension of the Pine Valley Mountains separated from the Escalante Valley by the Antelope Range fault. Prisms with densities of $2400 \mathrm{~kg} \mathrm{~m}^{-1}$ represent Cretaceous and lower Tertiary sedimentary rocks, and Tertiary volcanic units. These units are exposed in the mountains in the southeast portion of the study area, and are present in the subsurface beneath the Escalante Valley. Prisms of densities ranging from 1900 to 2125 $\mathrm{kg} \mathrm{m}^{-1}$ represent alluvial, fluvial, and lacustrine deposits of the Newcastle graben and the Pinto graben. The model depicts the Antelope Range fault dipping at an angle of $65^{\circ}\left( \pm 5^{\circ}\right)$ to the northwest.

Researchers from the Earth Science Laboratory, University of Utah Research Institute, assisted by UGMS personnel, conducted electrical resistivity and SP surveys. Within the area of suspected upflowing thermal fluid (in close proximity to the surface trace of the Antelope Range fault), these surveys disclosed sharply defined electrical anomalies. The anomalies are likely caused by fluids moving upward along narrow channelways associated with the Antelope Range fault. Permeable horizons within alluvium allow the hot fluid to discharge beneath the floor of the Escalante Valley into a shallow aquifer.

\section{Hydrochemistry}

We collected water samples from six wells in the study area for analysis of major anions and cations. Two of the wells sampled were geothermal production wells, one was a warm irrigation well, and the remaining three wells were all cold irrigation wells. Water chemistries suggest that geothermal fluid possesses a distinct character (moderate total dissolved solids) and mixes to varying degrees with cool, fresh groundwater. The geothermal fluid, after entering the shallow aquifer disperses to the north and west into the Escalante Valley becoming increasingly mixed.

We collected fluid samples from two geothermal wells, one mine dewatering well on the west side of the Escalante Valley, and four springs located in the highlands off to the east of the study area for determination of $\delta \mathrm{D}$ and $\delta^{18} \mathrm{O}$. The results of the analyses suggest that the geothermal fluid has undergone little isotopic exchange with reservoir 
rocks and that the water is of local meteoric origin. The most likely recharge area is the Pine Valley mountains located to the southeast.

\section{Soil-Gas Investigations}

Because of the mobility of mercury and radon within geothermal systems, we initiated a sampling program to determine the soil mercury content and radon flux across the temperature anomaly at Newcastle. We gathered soil samples for the mercury determinations, and placed radon detectors in shallow, 2 foot-deep holes. Presently, the results of these studies are inconclusive. From 110 soil samples, we expected to see relatively high mercury values over the thermal anomaly with respect to background. The highest mercury values recorded, however, were only two standard deviations above the mean, and occurred in only three samples. Moreover, high readings formed relatively isolated patterns of only marginal interpretive value. Patterns of high radon flux were observed at places along the trace of the Antelope Range fault and near the center of the thermal anomaly.

\section{Conceptual Model}

The working model we use for groundwater movement in this blind geothermal system consists of:

1. Recharge in the Pine Valley Mountains circulates to a depth of 5 kilometers within a postulated northwest- trending structural zone and is heated in a region of elevated heat flow $\left(\sim 90 \mathrm{~mW}^{-2}\right)$.

2. The northeast-trending Antelope Range fault and its intersection with the northwest-trending structural zone provides preferred pathway(s) for localizing discharge of geothermal fluid at the basin-fill/bedrock contact beneath the Escalante Valley.

3. Siliceous or carbonate precipitates formed at the interface between thermal and non-thermal water in the basin-fill possibly form a lowpermeability "seal" forcing geothermal fluid to flow upward.

4. Geothermal fluid discharges at a temperature of $130^{\circ} \mathrm{C}$ or greater into alluvium, near the ground surface, forming an outflowing "plume" of thermal water, eventually mixing with shallow groundwater and cooling. 


\section{Conclusions and Recommendations}

The thermal water produced from wells at Newcastle results from the upflow of hot water near the range front and subsurface outflow within a shallow aquifer. Our mapped temperature anomaly near the surface trace of the Antelope Range fault is based mostly upon shallow (less than $20 \mathrm{~m}$ ) drill holes that did not encounter hot fluid. Electrical geophysical surveys have provided more detail regarding the near-surface character of the upflow zone. To date, however, no drilling has taken place to adequately test the throat of the system.

We recommend (1) deep drilling to test SP and resistivity anomalies near our mapped temperature anomaly; (2) fluid sampling for common ion and isotopic analyses from the upflow portion of the geothermal system; (3) additional structural mapping and analysis in the Pine Valley mountains to test the integrity of our postulated northwesttrending structural (recharge) zone; and (4) a regional review of temperature, water chemistry, and geologic information to help identify prospective targets for other blind geothermal systems. 


\section{ACKNOWLEDGMENTS}

Funding for this work was provided in large part by the U.S. Department of Energy (grant no. DE-FG07-88ID12756). The Utah Geological and Mineral Survey (UGMS) provided support for portions of the geophysical and geological studies as well as contributing personnel salaries as part of all project tasks. The Unocal Geothermal Division of the Unocal Corporation generously provided temperature and other geophysical data from their Christiansen \#1 Well.

Gravity data were acquired during the Fall of 1987 and Fall of 1988 by students and teaching assistants in Dr. Charles M. Schlinger's gravity and magnetic methods course (Department of Geology and Geophysics, University of Utah). Participants included Susanne Janecke, Joann Hollaway, Rick Hulse, Peter Eick, Jim Hollis, Farhang Namdar, Tim Chisholm, Tony Robertson, and Sean Willett. Reductions of gravity data were made possible using computer programs written by Peter Eick and Jim Hollis.

Dr. Howard Ross of the Earth Science Laboratory, University of Utah Research Institute provided technical guidance on certain geophysical aspects of the project, in addition to directing resistivity and spontaneous potential surveys. Mr. Claron Mackelprang, an independent consultant, assisted Dr. Ross with the resistivity data collection and interpretations. Bea Mayes of the UGMS also helped in the performing of the resistivity survey and with the placement of radon detectors.

Brian J. (B.J.) Macpherson, a graduate student at the University of Utah, assisted with the gathering of temperature gradient and fault-slip data. B.J. was also responsible for compiling thermal conductivity and heat flow information.

Archie Smith, formerly of the UGMS, helped originally conceive the study and became an advocate for the project. He was instrumental in organizing the proposal effort and obtained support for the acquisition of detailed gravity and magnetic data, and the purchase of aeromagnetic maps acquired from USX Corporation.

We wish to express our thanks to Boyd Christensen, Carroll Tullis, Dan Tullis, Steven Christensen, George Becham, and the other residents of Newcastle for their assistance. We also thank Mary Siders, Peter Rowley, Gary Christenson, and G. Galyardt for permission to use unpublished mapping, and Ze'ev Reches for the use of his stress tensor programs. 


\subsection{INTRODUCTION}

\subsection{General Statement}

Undiscovered hydrothermal systems represent a significant portion of the total hydrothermal accessible resource base in the United States, estimated between 3 and 5 times that of identified hydrothermal systems (Muffler, 1979, p. 157). Many of these undiscovered systems are so-called "blind" systems where no surface expression of hydrothermal activity, such as thermal springs, sinter mounds, alteration minerals, etc., exists. Our work effort characterizes one such blind system located in southwestern Utah, discovered by accident, near the community of Newcastle.

\subsection{Purpose and Scope}

This work is the result of a response to a Program Research and Development Announcement (PRDA) for state cooperative geothermal research. The U.S. Department of Energy (DOE) solicited studies through the PRDA in April 1987. In response to the PRDA, the Utah Geological and Mineral Survey (UGMS) and the University of Utah Department of Geology and Geophysics (UUGG), prepared a joint proposal for cost-shared research at Newcastle. The original proposal was submitted in June 1987. At DOE's request, clarifications to the original proposal were made and a revised proposal was submitted for consideration in October 1987. The revised technical proposal and budget was eventually accepted and funding was allocated for the work. The project officially began in June 1988, with technical tasks continuing until November 1989.

One goal of this project was to better define the geothermal system at Newcastle. Another goal was to help establish a basis for an exploration methodology for other blind hydrothermal systems that may be present in the Basin and Range province. This report describes in detail a multidisciplinary study of the Newcastle geothermal area, situated in Iron County, Utah. The broad objective was to construct a refined, conceptual model of the hydrothermal system.

A major component to the determination of a correct geologic/geohydrologic model was to define the geometry of controlling geologic structures, the configuration of the enclosing basin fill, and postulate the movement of geothermal fluid. To this end, the project tasks consisted of several coordinated activities including: (1) geologic mapping of Quaternary deposits; (2) geologic mapping of bedrock in the adjacent mountains; (3) acquisition and analysis of gravity data and aeromagnetic data; (4) collection and analyses of water samples for common ions and light stable isotopes, plus investigations of mercury and radon concentrations in the soils around the thermal area; (5) thermal gradient monitoring in shallow, exploratory drill holes; and (6) numerical modelling of the hydrothermal system. An electrical resistivity survey and a spontaneous potential (SP) survey was later performed by researchers from the Earth Science Laboratory/University of Utah Research Institute. 
potential (SP) survey was later performed by researchers from the Earth Science Laboratory/University of Utah Research Institute.

\subsection{Background and Previous Work}

Newcastle is a rural farming community situated in southwestern Utah (Figure 1) where, in 1975 during test pumping of an irrigation well, a local farming company (known as the Christensen Brothers) discovered thermal water (Rush, 1983, p.19). The discovery well encountered a hot-water aquifer with a maximum temperature of $108^{\circ} \mathrm{C}$ $\left(226^{\circ} \mathrm{F}\right)$ between depths of 85 and $95 \mathrm{~m}(279$ and $312 \mathrm{ft})$. This was the first record of geothermal activity at Newcastle, although local residents describe an incident during the early settlement history of the valley when settlers, hand-digging a water well, abandoned the endeavor because of excessive heat in the well.

Since the drilling of the discovery well, several organizations and individuals have studied the system. Denton (1976) conducted a helium-gas survey across the area and detected a broad helium anomaly around the discovery well and along the nearby rangefront fault. Rush (1977) compiled temperature-gradient data for the Escalante Valley and other areas in Utah, and reported the results. Pe and Cook (1980) conducted a gravity survey in the region and defined a large, northeast-trending gravity low centered northwest of the town of Newcastle, which they interpreted as representing a deep graben.

Chapman and others (1981), using temperature gradient data obtained from various geothermal companies, calculated the thermal power loss of 13 megawatts from an area of $9.4 \mathrm{~km}^{2}\left(3.6 \mathrm{mi}^{2}\right)$, assuming a water temperature of $110^{\circ} \mathrm{C}\left(230^{\circ} \mathrm{F}\right)$ and a discharge rate of $321 \mathrm{~s}^{-1}\left(507 \mathrm{~g} \mathrm{~m}^{-1}\right)$. Rush (1983), using chemical geothermometry, estimated a reservoir temperature of $140^{\circ} \mathrm{C}$ to $170^{\circ} \mathrm{C}\left(284^{\circ} \mathrm{F}\right.$ to $\left.338^{\circ} \mathrm{F}\right)$ and published a chemical analysis of the Newcastle thermal water, temperature profile of the Christensen Brother's discovery well, potentiometric map of the area, temperature map at a depth of $100 \mathrm{~m}(328 \mathrm{ft})$, and a heat flow map of the principal hot water aquifer. Hoover (1987) reported the results of eight audio-magnetotelluric soundings in the Newcastle area, with the lowest resistivity values measured at a station east of the Christensen Brother's well. Mabey and Budding (1987) compiled available data on the Newcastle system and presented a geothermal model suggesting that hot water rising along a fault zone near the base of the hills southeast of Newcastle discharges into an aquifer in unconsolidated Quaternary sediments. Blackett (and others, 1989) briefly reported the results of temperature gradient drilling, geologic mapping, and water chemistry as part of this project. 


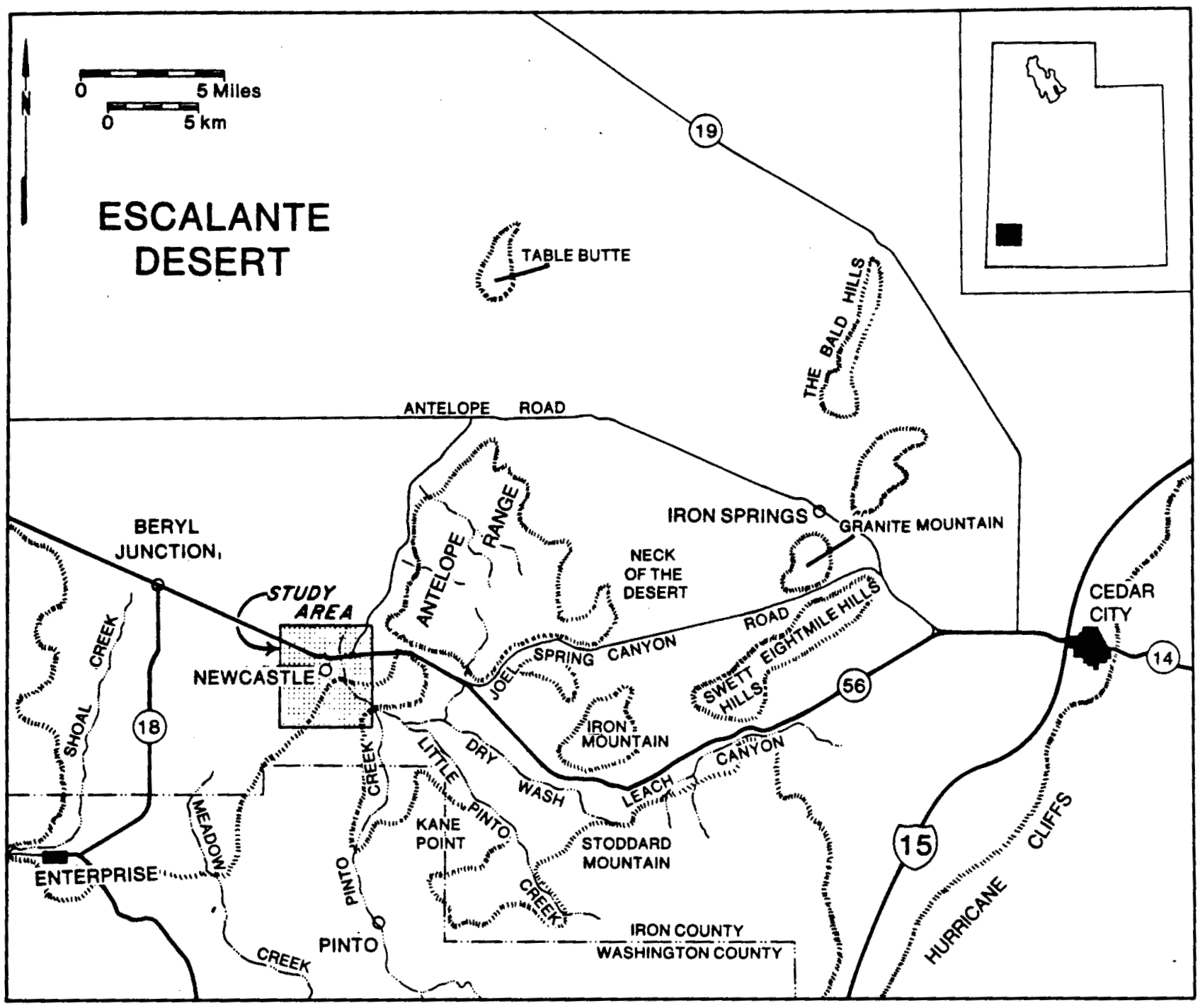

Figure 1. Location map showing the study ares In relation to the communitles of Cedar City and Enterprise, Utah. Geographlc features are labeled.

\subsection{Location and Regional Setting}

Newcastle is located about $48 \mathrm{~km}$ (30 mi) west of Cedar City, Utah along SR 56. Cedar City lies approximately $440 \mathrm{~km}(275 \mathrm{mi})$ southwest of Salt Lake City via Interstate 15. The communities of Enterprise and St. George lie approximately $13 \mathrm{~km}(8 \mathrm{mi})$ to the southwest and $64 \mathrm{~km}(40 \mathrm{mi})$ to the south of Newcastle, respectively. Other notable geothermal areas within the region include Roosevelt Hot Springs, located roughly 105 $\mathrm{km}(65 \mathrm{mi})$ to the northeast, and Cove Fort -- Sulphurdale, located roughly $120 \mathrm{~km}$ (75 $\mathrm{mi})$ to the northeast.

The Sevier thermal area was defined by Mabey and Budding (1987) to include a large area of western Utah where young igneous rocks, complex geologic structure, high regional heat flow, and seven high-and moderate-temperature geothermal systems are 
present. The seven geothermal systems within the Sevier thermal area (Figure 2) occur in or along the margins of intermontane valleys in the eastern part of the Basin and Range geologic province. Six of the systems occur within $70 \mathrm{~km}(44 \mathrm{mi})$ of the eastern province boundary.

The area is characterized by many late-Cenozoic normal faults. The Intermountain seismic belt, a zone of increased earthquake activity identified by Smith and Sbar (1974) that trends through northern and southwestern Utah, changes direction in the area from

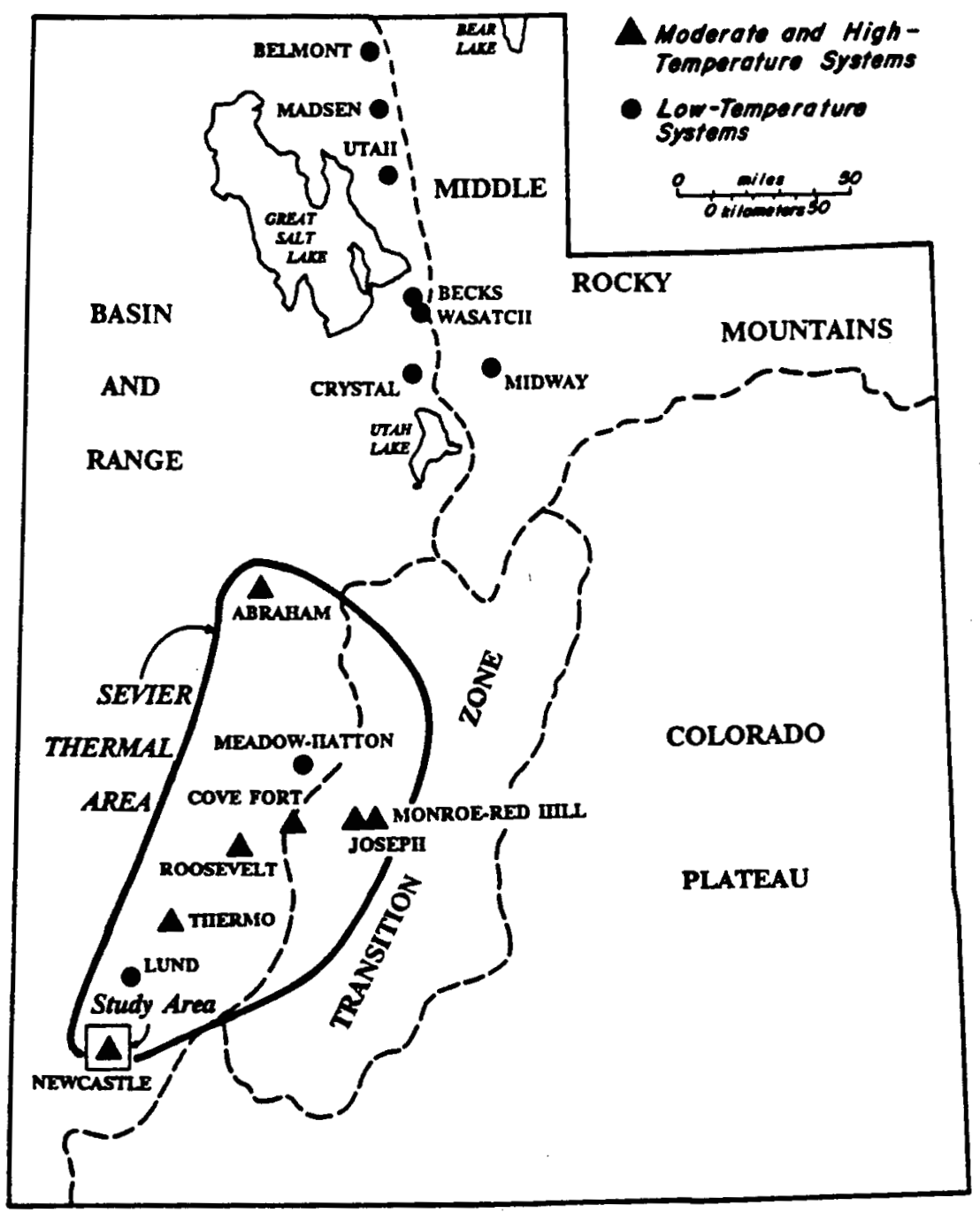

Figure 2. Map showing the location of the project area with respect to Utah's physiographic provinces and other major geothermal systems. The approximate outline of the Sevier thermal area, described by Mabey and Budding (1987), is also shown. 
a northerly orientation to a more southwesterly one. Oligocene and Miocene intrusive and extrusive igneous rocks are widespread in the southern part of the Sevier thermal area. A zone of younger extrusive igneous rocks, containing abundant Quaternary age basalt, trends across the northern part of the Sevier thermal area.

The presence of these higher-temperature geothermal systems in southwestern Utah relates to a high regional heat flow, and to complex geologic structures -- conditions that do not exist elsewhere in the state. High heat flow and complex structure, coupled with ample recharge fluids, creates conditions favorable for the development of hydrothermal convection systems. In addition, young igneous systems may supply heat to some of the geothermal systems in the Sevier thermal area (Mabey and Budding, 1987, p.4).

The Escalante Valley, sometimes termed "Escalante Desert," lies within the Sevier thermal area. It is an elliptical depression extending over an area measuring approximately $70 \times 45 \mathrm{~km}(44 \times 28 \mathrm{mi})$ and is surrounded by mountain ranges and hills composed dominantly of Tertiary ash-flow tuff units ranging in age from 32 to 19 million years ago (Ma), and rhyolite and dacite flows and domes ranging in age from 13 to 8.5 Ma. The valley is filled with more than $300 \mathrm{~m}(1,000 \mathrm{ft})$ of alluvial, colluvial, fluvial, lacustrine, and aeolian unconsolidated and semi-consolidated deposits (Klauk and Gourley, 1983, p.3).

Klauk and Gourley (1983, p.3) describe four significant events that have affected the Escalante Valley: (1) large scale thrust faulting of the Sevier orogeny; (2) east-west trending igneous activity; (3) Basin and Range tectonism; and (4) periods of intensive volcanism with associated intrusive activity. Sevier age thrust faults have been mapped near the Escalante Valley, and evidence of Paleozoic strata thrust upon Jurassic strata is present in at least one deep exploratory well within the valley (Mike Shubat, personal comm.).

The valley is situated between two major, roughly east-west trending mineral (or igneous) belts. The Pioche-Marysvale mineral belt ( $26 \mathrm{Ma})$ lies to the north, and the Delamar-Iron Springs mineral belt (20 Ma) lies to the south (Rowley and others, 1979). The Pioche-Marysvale and the Delamar-Iron Springs igneous belts are thought to be structurally controlled, and are associated with two east-west oriented lineaments -- the Blue Ribbon lineament to the north and the Timpahute lineament to the south (Figure 3). 


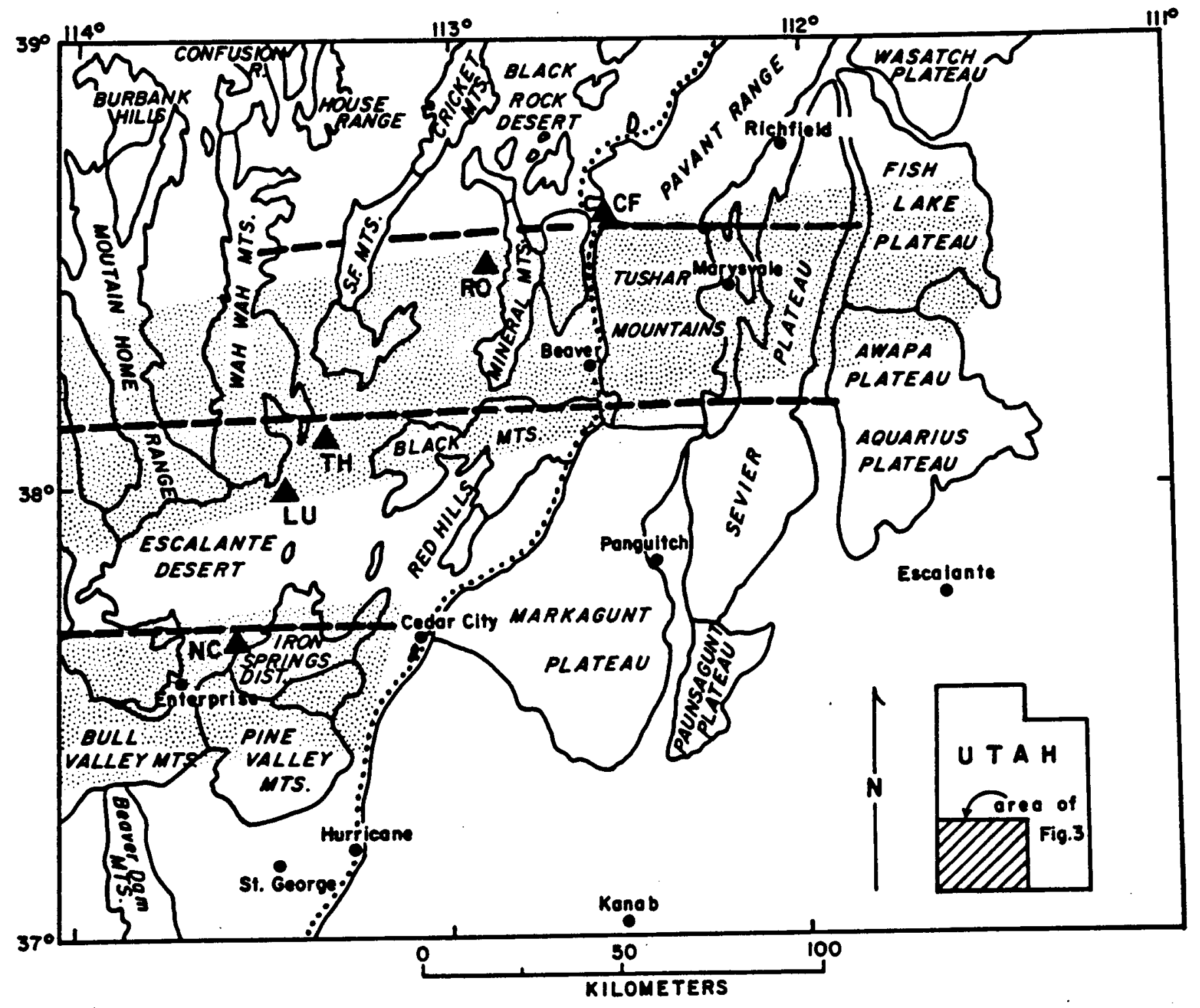

Figure 3. Physlographlc and major structural features of southwestern Utah - Colorado Plateaus boundary shown by heavy dotted line. Central part of Ploche-Marysvale Igneous belt on the north, and Delamar-Iron Springs Igneous belt on the south are shown in the stlpple pattern. Heavy dashed lines Indicate axes of lineaments - from north to south - the Black Rock, Blue Rlbbon, and TImpahute lineaments. Towns and ctties are noted. Geothermal areas are shown as solld trlangles and Include NC-Newcastle, LU-Lund, TH-Thermo, RORoosevelt, and CF-Cove Fort (modifled from Rowley and others, 1979). 


\subsection{GEOLOGIC INVESTIGATIONS}

\subsection{Mapping of Bedrock and Surficial Units}

Plates 1 and 2 are a geologic map and an accompanying sheet of cross sections and explanatory material for the Newcastle geothermal area. The geologic map shown in Plate 1 was taken from Siders and others (1989) and modified during this study.

\subsubsection{Stratigraphy}

Exposed bedrock units at Newcastle (described in detail by Siders and others, 1989) range in age from Upper Cretaceous to upper Miocene, and consist of older sedimentary rocks overlain by a series of middle Tertiary ash-flow tuffs of regional extent, and capped by local rhyolite and dacite flows. The oldest unit exposed is the Upper Cretaceous Iron Springs Formation, which consists of light-colored, thin- to thick-bedded sandstone and lesser shale, conglomerate, limestone, and carbonaceous shale. The unit was deposited in braided fluvial and lacustrine environments with sediment derived from the now-foundered Sevier orogenic highland that was located to the west. The minimum exposed thickness is $430 \mathrm{~m}$ (1400 ft). The Eocene to Oligocene Claron Formation unconformably overlies the Iron Springs Formation and consists of fluvial and lacustrine shale, sandstone, limestone, siltstone and conglomerate. The unit has a minimum exposed thickness of $130 \mathrm{~m}(430 \mathrm{ft})$ and is estimated to be about $210 \mathrm{~m}(700 \mathrm{ft})$ thick.

Overlying the Claron Formation is the Oligocene Isom Formation, which consists of two densely-welded, crystal-poor, ash-flow tuff members of regional extent, the lower Baldhills Tuff Member and upper Hole-in-the-Wall Tuff Member. Both members contain sparse phenocrysts of plagioclase, clinopyroxene, and magnetite and range in color from dark brown to black. Extreme welding produced flattened pumice clasts as much as $0.6 \mathrm{~m}(2 \mathrm{ft})$ in length, and secondary flowage produced stretched vesicles as much as 0.3 $\mathrm{m}(1 \mathrm{ft})$ in length. Intercalated with densely-welded tuff near the base of the Baldhills Tuff Member are probable andesitic flows marked by autobrecciation and flow-top scoria, and thin beds of volcanic sandstone. The minimum thickness of the Baldhills Tuff is 330 $\mathrm{m}(1,080 \mathrm{ft})$. The Hole-in-the-Wall Tuff Member consists of a single cooling unit that is about $79 \mathrm{~m}$ ( $260 \mathrm{ft}$ ) thick. The concealed source caldera or vent for the Isom Formation probably lies beneath the southern margin of Hamblin Valley or the northern margin of the Escalante Desert (Best, 1987), approximately $35 \mathrm{~km}$ (22 mi) northwest of Newcastle. The age of the Isom Formation is approximately $26 \mathrm{Ma}$ (Rowley and others, 1979).

Three regional rhyodacitic to dacitic ash-flow tuffs of the Quichapa Group overlie the Isom Formation and were probably erupted from sources in the Caliente caldera complex depression (Williams, 1967). The rhyodacitic, moderately-welded Leach Canyon Tuff, consisting of several cooling units, is approximately $25 \mathrm{Ma}$ (Rowley and others, 1979), and contains 20 to 30 percent phenocrysts of plagioclase, quartz, sanidine, and 
biotite and reddish lithic fragments. It is about 580 feet $(177 \mathrm{~m})$ thick in the map area. The Bauers Tuff of the Condor Canyon Formation is rhyodacitic, crystal-poor, denselywelded, approximately $23 \mathrm{Ma}$ (Rowley and others, 1979), and about $130 \mathrm{~m}$ (430 ft) thick. The tuff contains phenocrysts of plagioclase, sanidine, and bronze biotite and abundant highly-flattened pumice clasts. The Bauers Tuff erupted from the Clover Creek caldera located in Lincoln County, Nevada (Rowley and Siders, 1988). The Harmony Hills Tuff is a distinctive crystal-rich, dacitic, moderately-welded tuff dated at about 21 $\mathrm{Ma}$ (Rowley and others, 1979). It consists of nearly 50 percent crystals of plagioclase, biotite, hornblende, quartz, and pyroxene and is $146 \mathrm{~m}$ (480 ft) thick. An unnamed aerially-extensive volcaniclastic unit, approximately $40 \mathrm{~m}$ (130 ft) thick, overlies Harmony Hills Tuff and contains abundant clasts and crystal fragment, of Harmony Hills Tuff as well as andesite cobbles. This northward-thickening unit is probably a distal debris-flow deposit shed from an andesitic highland to the north.

The Racer Canyon Tuff overlies the Quichapa Group rocks and is the youngest regional ash-flow tuff present at Newcastle. The tuff is crystal-rich, rhyodacitic, poorly to moderately welded, and greater than $150 \mathrm{~m}$ (490 feet) thick. Southeast of the map area the Racer Canyon Tuff consists of at least 3 cooling units and its age is approximately $19 \mathrm{Ma}$ (Siders, in press). An informally named unit, the Volcaniclastic rocks of Newcastle Reservoir, overlies the Racer Canyon tuff and is greater than $300 \mathrm{~m}$ (980 ft) thick. The unit is correlative with the informally named mine series of Siders (1985), which has a minimum age of $11.6 \mathrm{Ma}$. The unit consists of intercalated lenses of conglomerate, mudflow breccia, and sandstone, and most clasts are volcanic rocks. Rhyolite and dacite lava flows and domes overlie and intrude Racer Canyon Tuff in the northeast corner of the map area. These informally named units, the Rhyolite of Silver Peak and Dacite of Bullion Canyon, yielded K-Ar ages of 8.4 and $8.5 \mathrm{Ma}$, respectively (Shubat and Siders, 1988).

Overlying the bedrock units are a variety of unconsolidated to semi-consolidated deposits described in detail by Siders and others (1989). The oldest of the semiconsolidated deposits is upper Miocene to Pliocene in age (labeled Ts in plate 1) and consists of moderately consolidated boulder, cobble, and pebble conglomerate and sandstone. This coarse fluvial material was deposited at the margin of the Escalante Valley and probably underlies the geothermal area at depth. This may be the unit that

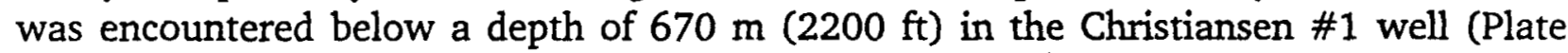
3 ). It corresponds to the higher density valley-fill material used in the gravity model (see later section). Overlying this unit is lower Pleistocene to Pliocene piedmont-slope alluvium (QTpo). This material is poorly- to moderately-consolidated and consists of boulder, cobble, and pebble conglomerate and sandstone. It contains a distinctive lithology, black magnetite ore, derived from Iron Mountain, located $10 \mathrm{~km}(6.2 \mathrm{mi})$ to the east. 
Units younger than the semi-consolidated deposits include several types of unconsolidated deposits of Pleistocene age. Stream-terrace alluvium (Qtm) consists of gravel, sand, and silt deposited in stream channels and flood plains at an elevation of approximately 15 to $25 \mathrm{~m}$ (50 to $80 \mathrm{ft}$ ) above modern channels. Piedmont-slope alluvium (Qpm) consists of sandy gravel forming dissected remnants of a surface in mountain front re-entrants that are older and higher than the modern one. Alluvial-fan deposits (Qfm) consist of sand and silt that form the dissected remnants of older and higher alluvial-fan deposits in the Escalante Valley. These older fans were largely deposited by ancestral Pinto Creek.

The youngest unconsolidated deposits consist of sand, silt, gravel, and clay divided on the basis of depositional environment and geomorphic expression. Colluvium and talus (Qct) includes deposits on steep slopes below rock outcrops. Alluvium and colluvium (Qac) includes material deposited in intermittent stream channels and on lower slopes as sheetwash and talus. Distal alluvial-fan deposits (Qpy) in the northwest past of the map consist of silt and clay deposited in the distal parts of the alluvial fans of Pinto Creek and other drainages to the southwest. They are derived principally from sheetwash and stream erosion of the coarser Pleistocene alluvial-fan deposits. Young alluvial-fan deposits (Qfy) are those deposited by Pinto Creek in the Escalante Valley, during Holocene and late Pleistocene time. Young stream-terrace alluvial deposits (Qty) occur about 2 to $3 \mathrm{~m}$ (6 to $10 \mathrm{ft}$ ) above the modern channel of Pinto Creek, and are chiefly Holocene-age. Alluvium (Qal) is restricted to modern channels and artificial fill (Qf) represents the earthen dam of Newcastle Reservoir.

\subsubsection{Structure}

Structural investigations at Newcastle included mapping of bedrock structures (M.A. Shubat), Quaternary structures (G.E. Christenson), and measurement of slip directions of minor faults (M.A. Shubat and R.E. Blackett) from four sites near Newcastle. The goal of these studies was to document the surface expression of structures that localize the geothermal resource at Newcastle.

The Antelope Range fault, as defined by Quaternary fault scarps, is a northnortheast striking normal fault that extends from Newcastle at its southwestern end to the northern tip of the Antelope Range, spanning a distance of $26 \mathrm{~km}$ (16 mi). At Newcastle, the fault separates the Escalante Valley to the northwest from the uplifted bedrock of the Antelope Range to the southeast. Although not marked by distinctive Quaternary-age scarps, the fault probably continues an additional $14 \mathrm{~km}(9 \mathrm{mi})$ to the southwest, terminating near Mountain Meadow. As mapped by Siders and others (1989), the fault breaks into three right-stepping en echelon strands east of Newcastle (Plate 1). Anderson and Christenson (1989) assign a middle to late Pleistocene age for the last surface-rupturing event, based on scarp morphology. Scarps on Pleistocene alluvium northeast of Newcastle, mapped by Grant and Proctor (1988) and Shubat and Siders 
(1988), are multiple-event scarps. Without additional information, it is not possible to determine if the southwestern limit of Quaternary scarps marking the fault represents the southwestern tip of the most recent surface-rupturing event or if scarps were simply not preserved southwest of Newcastle. Mapping by Siders and others (1989) and Shubat and Siders (1988) shows that the Antelope Range fault cuts 8.5 Ma rhyolite and dacite flows, indicating that initiation of the Antelope Range fault began in the late Miocene.

Gravity data indicate that the Antelope Range fault marks the southeastern margin of a northeast-trending, alluvium-filled graben named the Newcastle graben by $\mathrm{Pe}$ and Cook (1980). This graben, centered approximately $3.7 \mathrm{~km}(2.3 \mathrm{mi})$ northwest of Newcastle, contains a thick section of alluvium. Modeling of detailed gravity data collected during this study (see later section) indicates that the dip of the Antelope Range fault is steep (approximately $65^{\circ}$ ) and that the Newcastle graben contains about 1600 $\mathrm{m}(5,250 \mathrm{ft})$ of alluvium. This corresponds to nearly $1800 \mathrm{~m}(6,000 \mathrm{ft})$ of dip slip separation along the fault.

Geologic mapping of the range south and east of Newcastle revealed a complex pattern of steeply- to moderately-dipping faults that strike in all directions (Plate 1). Most faults show apparent normal separation, as determined by stratigraphic separation and dips from three-point solutions. However, the dominant displacement on map-scale faults, if similar to minor faults, may be strike-slip, as shown by the dominantly subhorizontal rakes of minor fault striae measured from several sites near Newcastle (Figure 4). Because of the absence of piercing points, we could not determine the net slip for any of the map-scale faults. Stratigraphic separation appears to be the greatest (610 to $910 \mathrm{~m} ; 2,000$ to $3,000 \mathrm{ft}$ ) and the most variable along northwest-striking faults and fault zones. One of these faults contains a very coarse breccia body (megabreccia) lying between two fault splays located in the northeast $1 / 4$ of section $29, \mathrm{~T} 36 \mathrm{~S}, \mathrm{R} 15 \mathrm{~W}$. This is a steep, apparent reverse fault and in the subsurface it projects northwesterly toward the center of the thermal anomaly (near holes NC-18 and NC-19, Plate 1). Plate 1 shows the map-view projection of this and other faults and contacts onto the footwall of the Antelope Range fault, assuming that it dips steeply $\left(65-70^{\circ}\right)$ toward the valley and strikes parallel to its surface trace. This projection shows that the center of the thermal anomaly coincides with an area where two prominent high-angle faults intersect in the plane of the range-front fault.

\subsection{Fault Slip Analysis}

We undertook a fault slip study at Newcastle in order to better understand the chronology of deformational events by collecting data from rocks of different ages and different locations. Fault slip analysis involves the fitting of a mean stress tensor to a population of fault slip measurements. Angelier (1979; 1984), Angelier and others (1985), and Reches (1987) developed the methods used in this study. To apply this technique, we measured many minor fault orientations from several outcrop-scale areas 


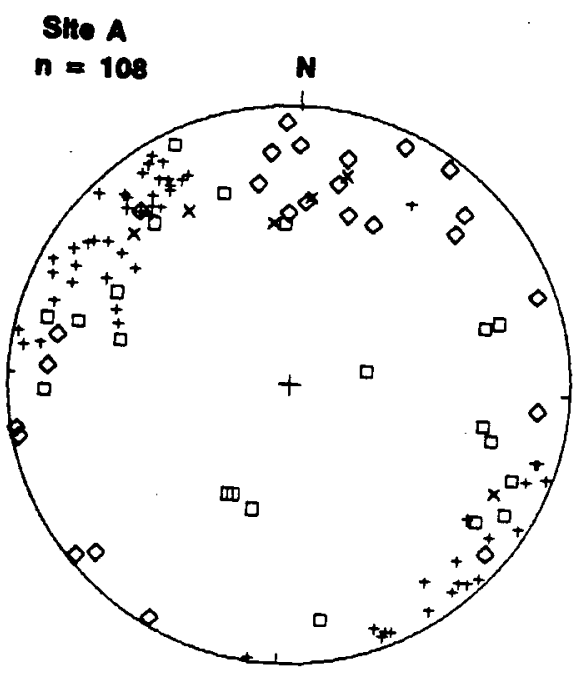

Silckonaldo Uneation

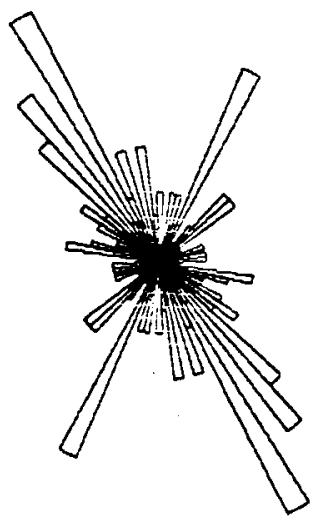

Strike

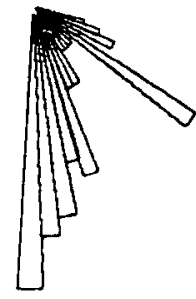

Dip

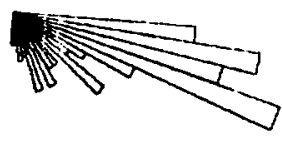

Rake

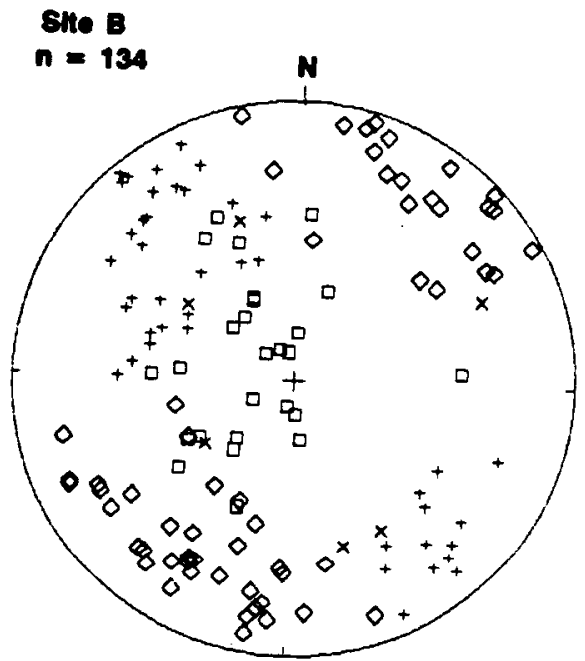

Slickenside Uneation

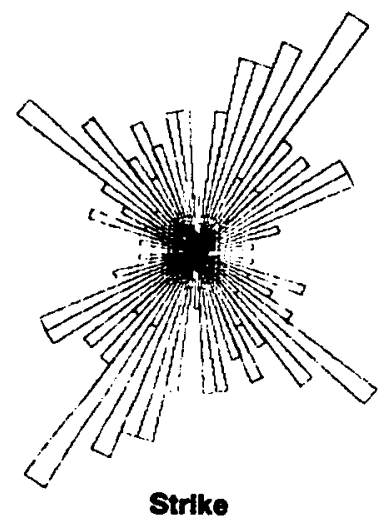

Strike
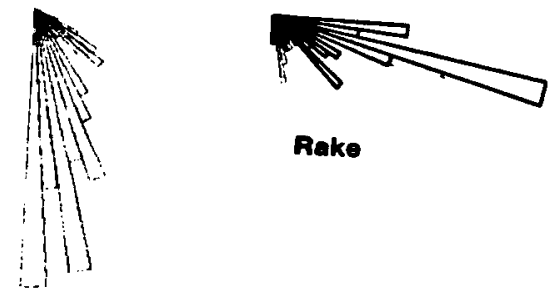

Rake

Dip

Figure 4a. Slip axes orlentations, strlke and dip of fault planes, and rake of slickensides for sltes
A, and B near Newcastle, Utah. For stereo plots, plus $(+)=$ dextral faults, of sltes shown In Figure 5 and described in text. and $x=$ reverse faults. 


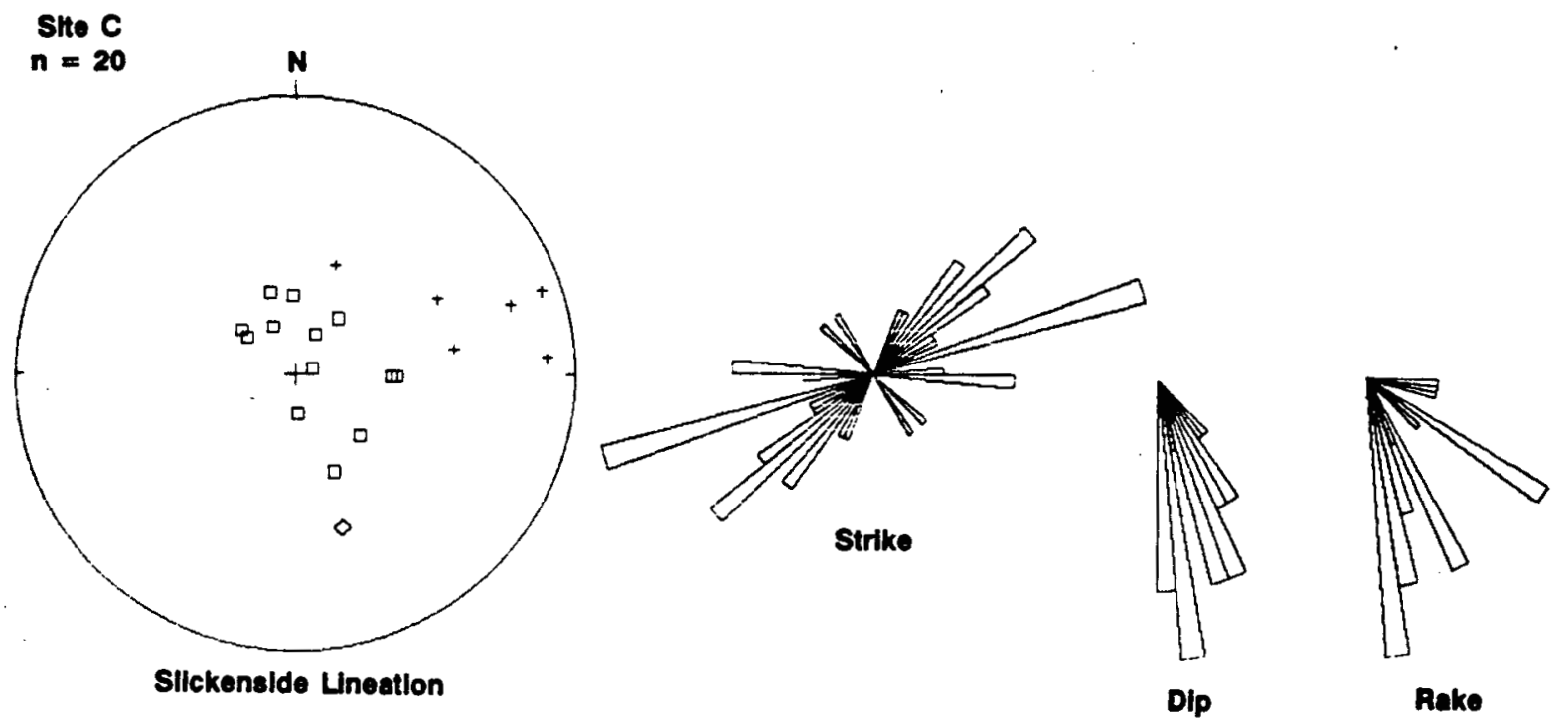

She D

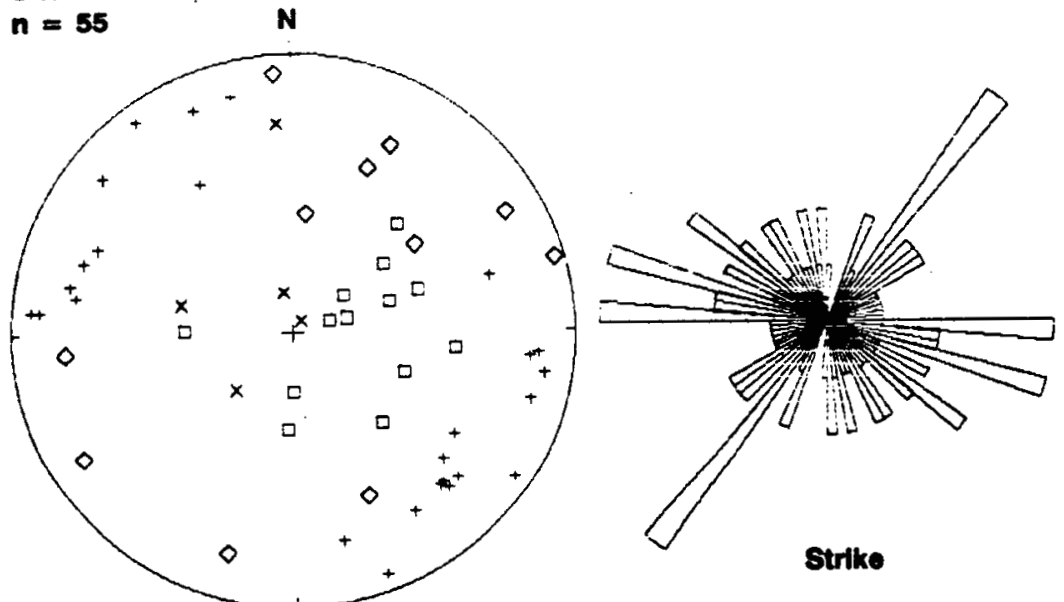

Sllokenalde Uneation
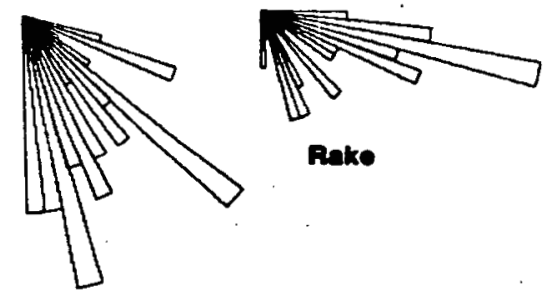

Rake

Figure 4b. Sllp axes orlentations, strike and dip of fault planes, and rake of sllckensides for sltes $C$ and D near Newcastle, Utah. Locations of sltes shown In Figure 5 and described in fext. For stereo plots, plus $(+)=$ dextral faults, diamond $=$ sinlstral faults, box $=$ normal faults, and $x=$ reverse faults. 
and for each fault recorded the strike, dip, rake, and sense of slip. These raw data appear in Appendix A. Petit (1987) and Angelier and others (1985) document the use of minor structures on fault planes to determine the sense of slip. In this study we found that riedel shears, tension gashes, and corniced margins of void spaces were the most consistent indicators of slip. On fault surfaces with only very minor displacement (on the scale of a few centimeters) we observed "tool-and-groove" indicators of slip, where a tool on one side of the fault (usually a quartz phenocryst) scratched a grove on the other side of the fault and then lodged in the head of the groove. We found that the Harmony Hills tuff contained a much higher density of minor fault surfaces than any other unit, probably as a result of favorable rock mechanic properties and preservation characteristics. In general, we were able to confidently determine the slip direction for only a fraction $(1 / 3)$ of the minor fault surfaces exposed in the field.

We collected data from four sites, three of which lie within the area of Figure 5 (sites A, B, and C). Faults at sites A and B cut the 21 Ma Harmony Hills Tuff, which yields the maximum age of these faults. Faults at site $\mathrm{C}$ cut $8.5 \mathrm{Ma}$ rhyolite and dacite, again yielding the maximum age of this set of faults. The number of faults measured for sites $\mathrm{A}, \mathrm{B}$, and $\mathrm{C}$ are 108,134 , and 20 , respectively. A fourth site, site $\mathrm{D}$, located in the NW $\frac{1}{4}, N E \frac{1}{4}, S W \frac{1}{4}$, section 19, T. 35 S., R. 14 W., was also sampled and yielded 55 measurements. This site lies about $12 \mathrm{~km}(7.5 \mathrm{mi})$ northeast of Newcastle, in Chloride Canyon, and was selected to provide a contrast to the Newcastle sites. Figure 4 shows the basic geometric data for the four sites (strike, dip, rake, and orientation of slickensides lineations).

We performed the analysis using software generously provided by $\mathrm{Z}$. Reches (Version 1.6). The method developed by Reches (1987) allows the user to interactively select a solution that satisfies the criteria listed by Reches (1987) and that minimizes two measures of misfit. These criteria are that the coefficient of friction be near 0.8 , the mean misfit angle be as small as possible, and the mean cohesion be greater than zero. One of the measures of misfit is the mean of the angle between the observed slip axis and the maximum resolved shear stress (calculated from an inversion-derived stress tensor) for each fault in the population. This tensor is derived by inverting a $2 \mathrm{k} \mathrm{x} 5$ matrix and solving the overdetermined system by the least squares method. Elements of the matrix are the coefficients of the components of the reduced stress tensor (Celerier, 1988). The first $k$ rows (where $k$ is the number of fault measurements) satisfy the constraint that slip is parallel to the maximum resolved shear stress and the remaining $\mathrm{k}$ rows satisfy the Coulomb yield criteria (Reches, 1987). The second measure of misfit is the mean of the average angle between the three principal axes of the general tensor solution for the population and the axes of the ideal stress tensor solution for each fault. The ideal tensor is one that minimizes the differential stress for a fault. 


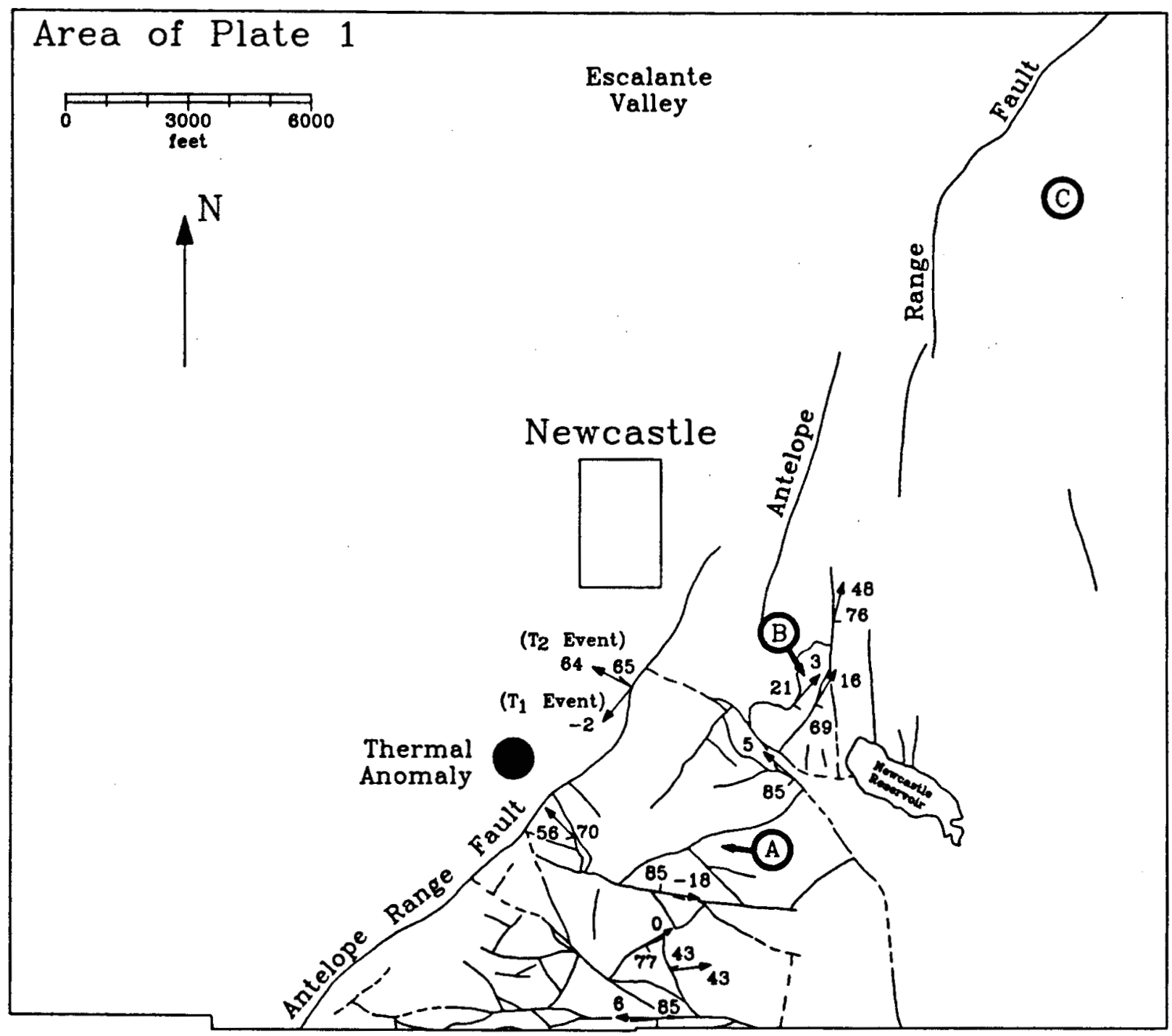

Figure 5. Index map of the Newcastle geothermal area showing the location of fault sllp data collection sltes (heavy circles with letter In center). Also shown are predlcted slip directions for some map-scale faults using reduced stress tensors determined in this study. Arrows and numbers show the trend and plunge of slip axes. Hachures and numbers show the dip direction and dip of the fault planes. Solld clrcle is the center of the thermal anomaly, near thermal gradient holes NC-18 and NC-19. 
These methods, and the results of fault slip analysis using software provided by $Z$. Reches, were checked using a program written by the authors, closely following the algorithm of Reches (1987). This program (INVERT), written in Turbo Pascal, version 4.0 , uses the singular value decomposition and chi-square minimization fitting procedures (and code) published by Press and others (1986). The program also uses an eigenvector determination procedure incorporated in the Turbo Pascal Numerical Methods Toolbox. Two other supporting programs were written to supplement Reches (1987) software; REFORMAT, which translates field data into the format required for Reches' software and the INVERT program, and SLIP, which calculates the predicted slip on a fault from the reduced tensor. All three of these programs are in Appendix B.

Table 1 lists the results of the analysis. We rotated the orientations of fault slip data for sites A and B to restore bedding to horizontal (rotation about the line of strike). The bedding orientations at sites $A$ and $B$ are $5^{\circ}, 6^{\circ}$ and $274^{\circ}, 13^{\circ}$ respectively (dip direction and dip). Data from site $C$ were not rotated because of the absence of bedding information. Data from site $\mathrm{D}$ were not rotated because the large dip at this site, $220^{\circ}, 44^{\circ}$ (dip direction and dip), and large slip axes misfit angles (Table 1) made interpretation of these data problematic.

Next, we performed a step wise removal of statistical outliers for sites A, B, and $C$ by examining histograms of the misfit angles. Each of these data sets yielded lognormal distributions of slip axis misfit angles and normal distributions of principal axes misfit angles. For each iteration, we removed data above the 95th percentile and recalculated the solution tensor and misfit angles. The percent of original data retained for each set, after removal of outliers, ranged from 65 to 87 percent. Removal of this data did not significantly alter the orientations of the axes of the solution tensors (Table 1), but greatly improved the accuracy of the solutions and reduced the mean misfit angles. Many factors probably account for the presence of these outliers, such as slumping of exposures and a failure for some of the faults to meet the assumption of the method. These assumptions are that the deformation occurred under a homogeneous state of stress, that slip along each fault occurred independently, and that slip was in the direction of maximum resolved sheer stress. Principal axes misfit results for site A showed a distinct bimodal distribution (Figure 6) that allowed us to separate these data into two subsets, listed as sites $A_{1}$ and $A_{2}$ in Table 1.

Results of this somewhat subjective interpretation of the data (interpretive in the sense of rotation of bedding, removal of statistical outliers, and the selection of a coefficient of friction) are shown in Figure 7. The very similar results obtained for sites $A_{1}, B$, and $D$ suggest that the same tectonic event $\left(T_{1}\right)$ produced these faults. The mean angular difference between the principal axes of solution tensors for these three sites is less than $3^{\circ}$. Likewise, the similar results obtained for sites $A_{2}$ and $C$ suggest that a separate tectonic event $\left(T_{2}\right)$ produced these faults. The mean angular difference between the principal axes of solution tensors for these two sites is about $11^{\circ}$. The dominance 
Table 1 - Results of Fault Slip Analysis, Newcastle, Utah

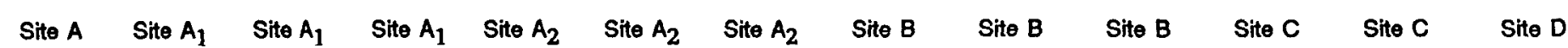

Unproces. Unrotated Unrotated, Rotated, Unrotated Unrotated Rotated, Unproces. Unrotated, Rotated Unproces. Outliers Unproces. Data Outliers Outliers Droces Removed Removed Removed Removed Removed Removed

Number of

Measurements

(\% Data

Retained)

Sigma 1

Trend/Plunge

Sigma 2

Trend/

Plunge

Sigma 3

Trend/

Plunge

Phi Value

Coefficient

of Friction

$108 \quad 84$

65

$65 \quad 24$

21
$(87 \%)$

$21 \quad 134$

3496

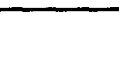

Date

Average

Slip-axis

Misfit

\begin{tabular}{|c|c|c|c|c|c|c|c|c|c|c|c|c|}
\hline $355 / 17$ & $355 / 14$ & $347 / 29$ & $354 / 6$ & $173 / 81$ & $195 / 77$ & $207 / 83$ & $352 / 10$ & $356 / 16$ & $352 / 7$ & $25 / 85$ & $358 / 81$ & $355 / 8$ \\
\hline $190 / 71$ & $185 / 74$ & $178 / 59$ & $177 / 82$ & $33 / 6$ & $34 / 11$ & $39 / 6$ & $114 / 69$ & $147 / 71$ & $166 / 82$ & $122 / 0$ & $218 / 6$ & $189 / 80$ \\
\hline $87 / 4$ & $85 / 2$ & $80 / 4$ & $84 / 0$ & $303 / 5$ & $304 / 3$ & $309 / 1$ & $259 / 16$ & $263 / 8$ & $262 / 0$ & $212 / 4$ & $127 / 5$ & $85 / 2$ \\
\hline 0.76 & 0.70 & 0.77 & 0.58 & 0.56 & 0.88 & 0.55 & 0.55 & 0.75 & 0.53 & 0.31 & 0.05 & 0.78 \\
\hline 0.00 & 0.00 & 0.40 & 0.00 & 0.40 & 0.31 & 0.40 & 0.00 & 0.40 & 0.21 & 0.00 & 0.40 & 0.00 \\
\hline 39.99 & 19.18 & 16.96 & 16.59 & 28.89 & 19.22 & 24.09 & 33.96 & 22.13 & 18.36 & 27.14 & 13.49 & 49.16 \\
\hline
\end{tabular}




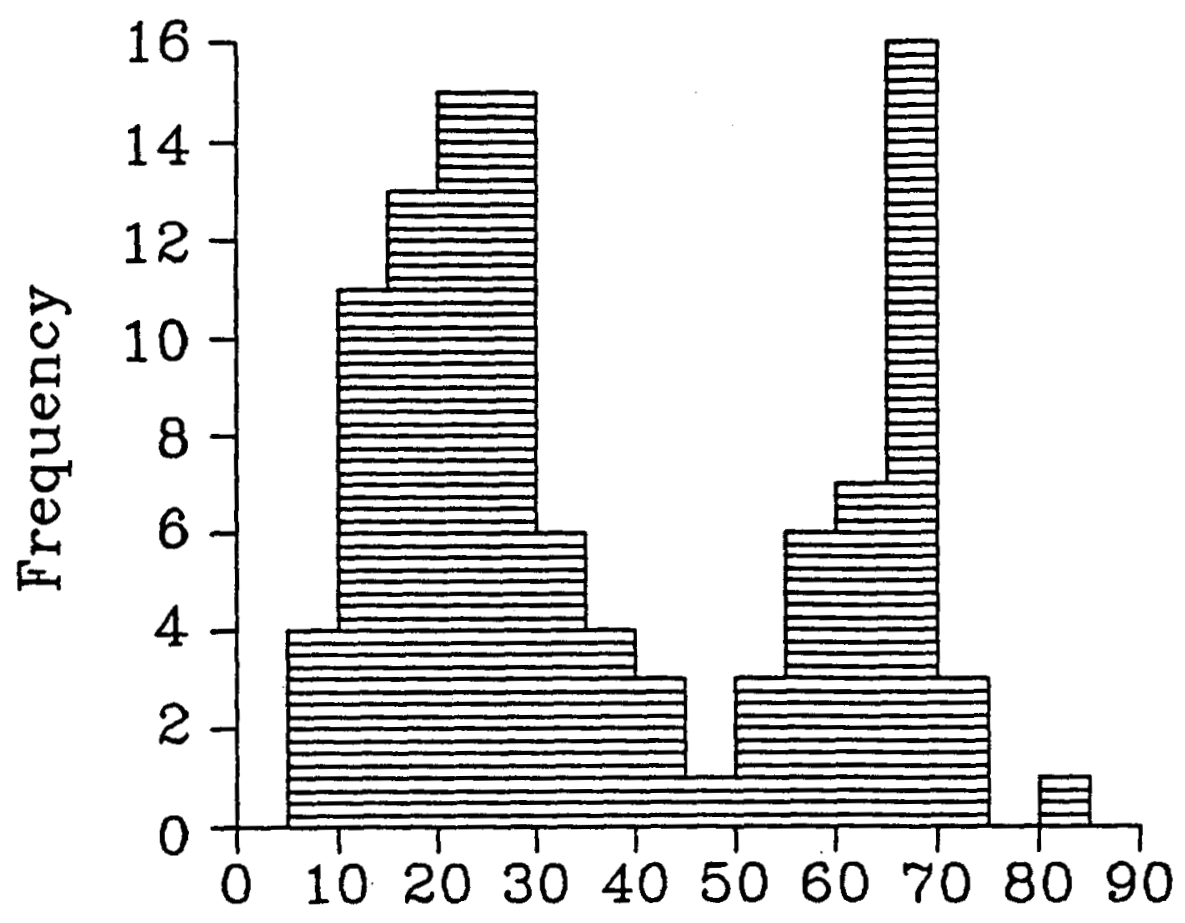

\section{Principal Axes Misfit (degrees)}

Figure 6. Frequency histogram of princlpal axes misft angles for site $A$. The prominent bimodal distribution was used to separate the data Into two subsets, labeled $A_{1}$ and $A_{2}$ in Table 1.

of the $T_{1}$ event in the fault population from site $A_{1}$ the high density of minor faults associated with the $T_{1}$ event (sites $A$ and $B$ ), and the absence of expression of the $T_{1}$ event at site $C$ argue that the $T_{1}$ event occurred prior to the eruption of the $8.5 \mathrm{Ma}$ rhyolite at site $C$ and that the $T_{2}$ event occurred after this eruption. From our data, we bracket the $T_{1}$ event between 21 and $8.5 \mathrm{Ma}$ and associate it with regional 17-8 Ma, southwest-directed extension recognized by many workers (Angelier and others, 1985; Anderson, 1987; Axen and Wernicke, 1987) in southeastern Nevada and southwestern Utah. Wernicke and others (1989) suggest that this extensional episode, in the Las Vegas region, was most intense between 15 and $11 \mathrm{Ma}$ and was characterized by a $S 70^{\circ} \mathrm{W}$ extension direction. This is close to the $262^{\circ}$ azimuth of sigma 3 obtained for sites $A$, $B$, and D (Figure 7). At Newcastle, this event probably produced most (if not all) of the faults exposed in the range south and east of Newcastle. We associate the $T_{2}$ event with the formation of the Antelope Range fault and the Newcastle graben and interpret these structures to be less than $8.5 \mathrm{Ma}$. The $T_{1}$ and $T_{2}$ events resemble the "pre-basin-range" and "basin-range" events described by Zoback and others (1981) in terms of timing, orientation, and style. Following from this interpretation we note that of the faults produced during the $T_{1}$ event, relatively few were reactivated during the $T_{2}$ event (at sites $A$ and $B$ ) and that the $T_{2}$ event generated only sparse new faults near the footwall of the 


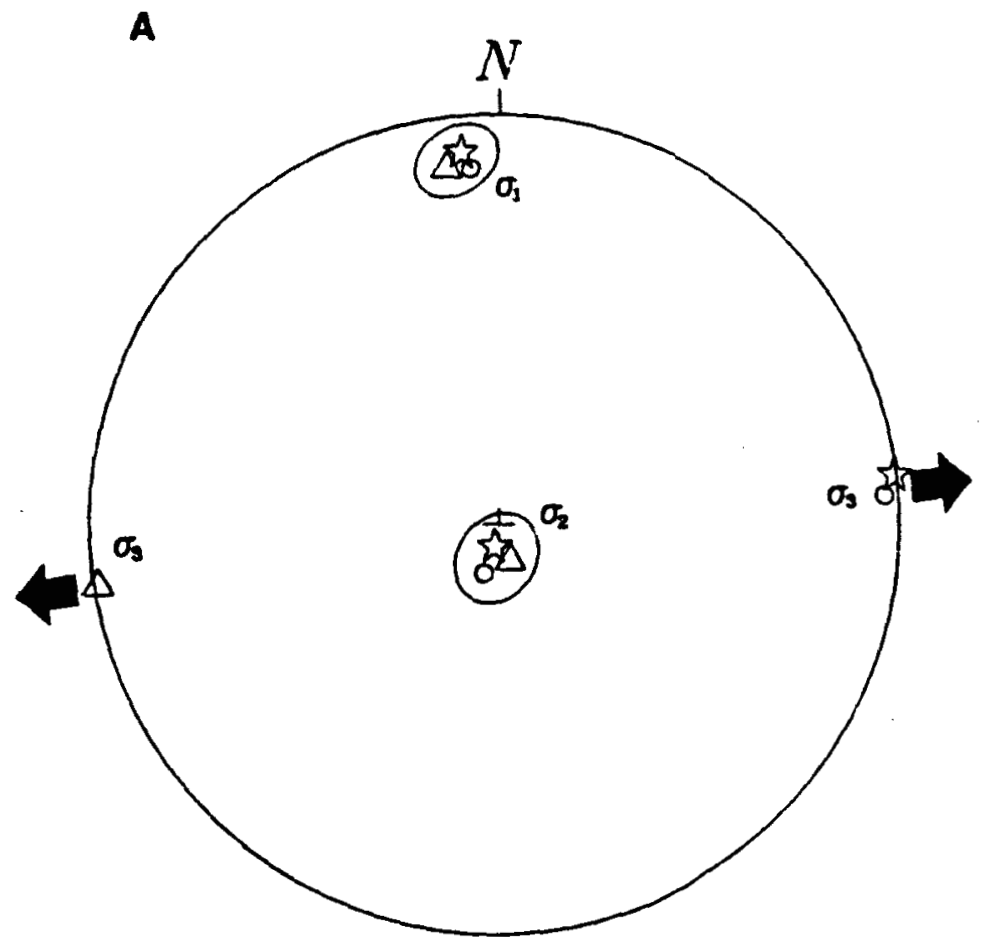

T1 Tectonic Event

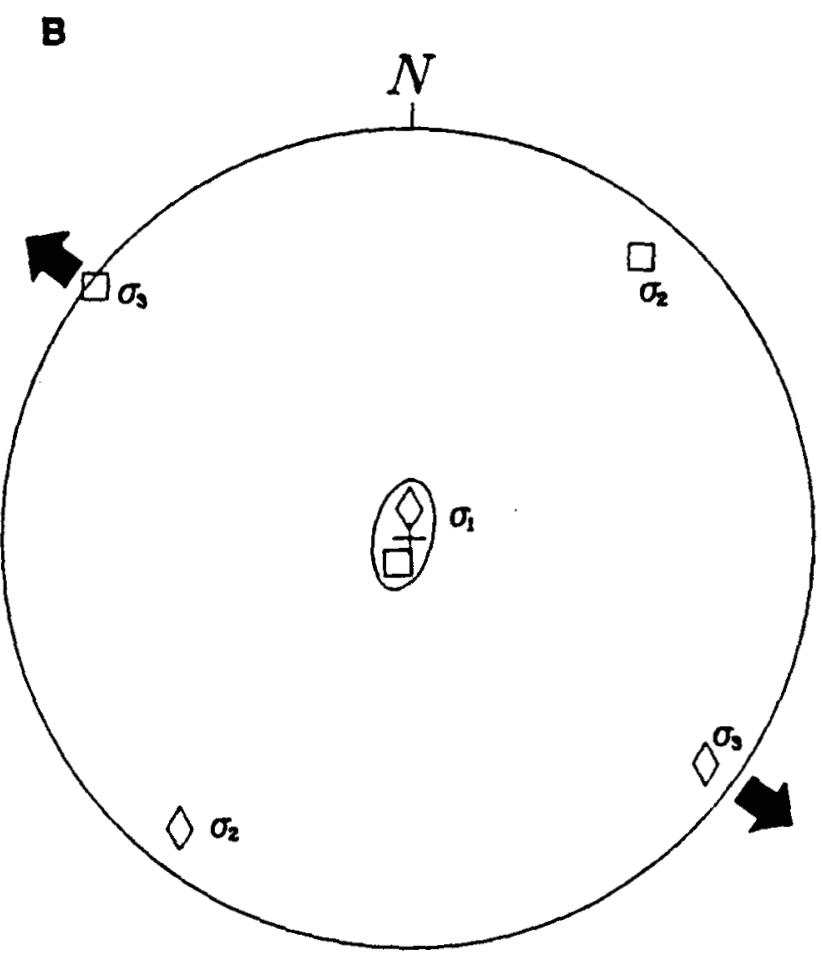

T2 Tectonic Event

Figure 7. Lower hemlsphere stereoplots (Wulfif nets) showing the orlentations of principal axes $\left(s_{1}, s_{2}\right.$, and $\left.s_{3}\right)$ of solution tensors

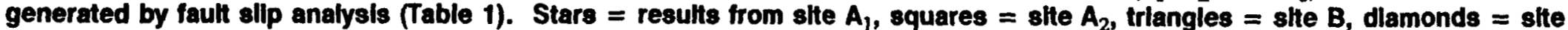
C, circles = site $D$. 
Antelope Range fault (site $\mathrm{C}$ ), apparently contributing little to the fault and fracture permeability of the bedrock away from the Antelope Range fault.

As in other studies of this type, the use of somewhat subjective form of data interpretation is defended by the coherent results obtained. The success of the method at sites $A_{1}$ and $B$, gauged by the close correspondence of results (Figure 7), suggests that the formation of most of the minor faults at these locations occurred prior to rotation of bedding. The close correspondence of unrotated results from site $D$ with rotated results form sites $A_{1}$ and $B$ suggest that most of the minor faults produced at site $D$ occurred after rotation of bedding.

\subsubsection{Relationship Between Map-scale Faults and the Fault Slip Analysis}

Because of the absence of piercing-points for map-scale faults, we cannot directly compare the observed slip with predicted slip using the stress tensors calculated above. In a qualitative sense, however, we note that slickensides observed adjacent to westnorthwest-striking faults throughout the map area have nearly horizontal rakes and are right-lateral in their sense of displacement, which matches the predicted slip for the $T_{1}$ event (Siders and others, 1989; written comm., P.D. Rowley, 1989; this study). We note that the predicted slip on the Antelope Range fault using the $T_{1}$ stress tensor yields a slip vector trending $220^{\circ}$ and plunging $-2^{\circ}$ (dominantly left-lateral with a slight reverse component, Figure 5). Clearly, slip along the Antelope Range fault during the $T_{1}$ event alone could not have produced the Newcastle graben as defined by gravity data. Applying the $T_{2}$ stress tensor to the geometry of the Antelope Range fault yields a slip vector trending $297^{\circ}$ and plunging $64^{\circ}$, suggesting nearly pure dip slip (Figure 5). To summarize our interpretations, Figure 5 shows the predicted slip for many map-scale faults with well-defined geometries, assuming that faults internal to the range formed during the $T_{1}$ event and that the Antelope Range fault formed during the $T_{2}$ event. 


\subsection{GEOPHYSICAL INVESTIGATIONS}

\subsection{Gravity and Magnetic Surveys}

\subsubsection{Objectives}

Because fracture permeability dominates control of fluid migration within hydrothermal systems, structural analysis becomes an important component of a geothermal investigation. At Newcastle, we proposed a combination of gravity and magnetic investigations to help determine subsurface geologic structure. Because highresolution, high cost methods such as seismic reflection were beyond the scope of the project, more affordable gravity and magnetic methods offered the best potential for low-to moderate-resolution of subsurface structure. The goals of the geophysical surveys included (1) determining the geometry (mainly attitude) of the Antelope Range fault, (2) determining if buried, hanging-wall structures exist, and (3) estimating the depth to bedrock within the Escalante Valley. Consequently, we worked to interpret data along profiles both normal and parallel to the trace of the Antelope Range fault. This work included some experimentation aimed at defining the utility of close-spaced, high-precision gravity surveys within tectonic environments characterized by Basin and Range-type normal faulting. We devoted the majority of effort to acquisition and interpretation of gravity data, because ground magnetic surveys proved ineffective due to various problems.

\subsubsection{Previous Work}

Eaton and others (1978) describe the relation of regional gravity and tectonic patterns in the Great Basin. Previous gravity and magnetic investigations of the Escalante Desert and vicinity, Iron and Washington Counties, Utah, by Pe (1980) focussed on regional variations. The principal regional gravity feature (Figure 8) is a northeastsouthwest trending gravity low, interpreted by $\mathrm{Pe}(1980)$ as a graben. The Newcastle geothermal system is located along the southeast margin of this graben. This margin is defined by the Antelope Range fault lying about one $\mathrm{km}$ east of the Newcastle town center and striking northeast-southwest (Plate 1). The regional magnetic anomaly map (Figure 9) shows no distinctive features associated with this graben structure. In general, there is little indication within existing data sets of small-scale subsurface structures.

\subsubsection{Magnetic Survey}

Initially, we had hoped to obtain useful information using both magnetic and gravity surveys. Other than regional aeromagnetic data, described above, no detailed magnetic data were available. A United States Steel Corporation (USX) aeromagnetic data set, although known to exist, was initially unavailable. Our first effort, during November 1987, involved acquiring ground-based magnetic data. Problems with instru- 


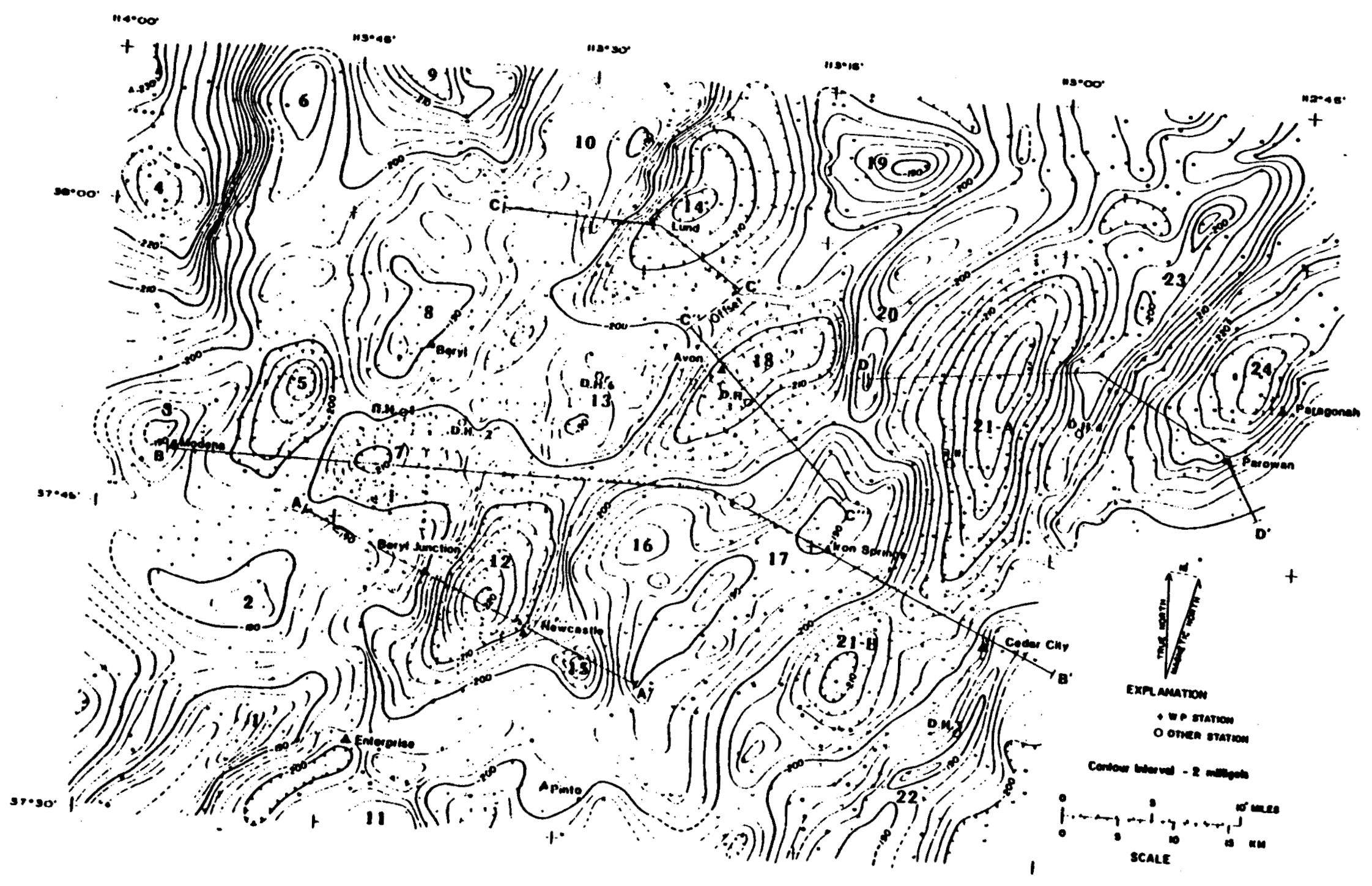

Figure 8. Complete Bouguer gravity anomaly map of southwestern Utah (after $P_{e}, 1980$ ). 


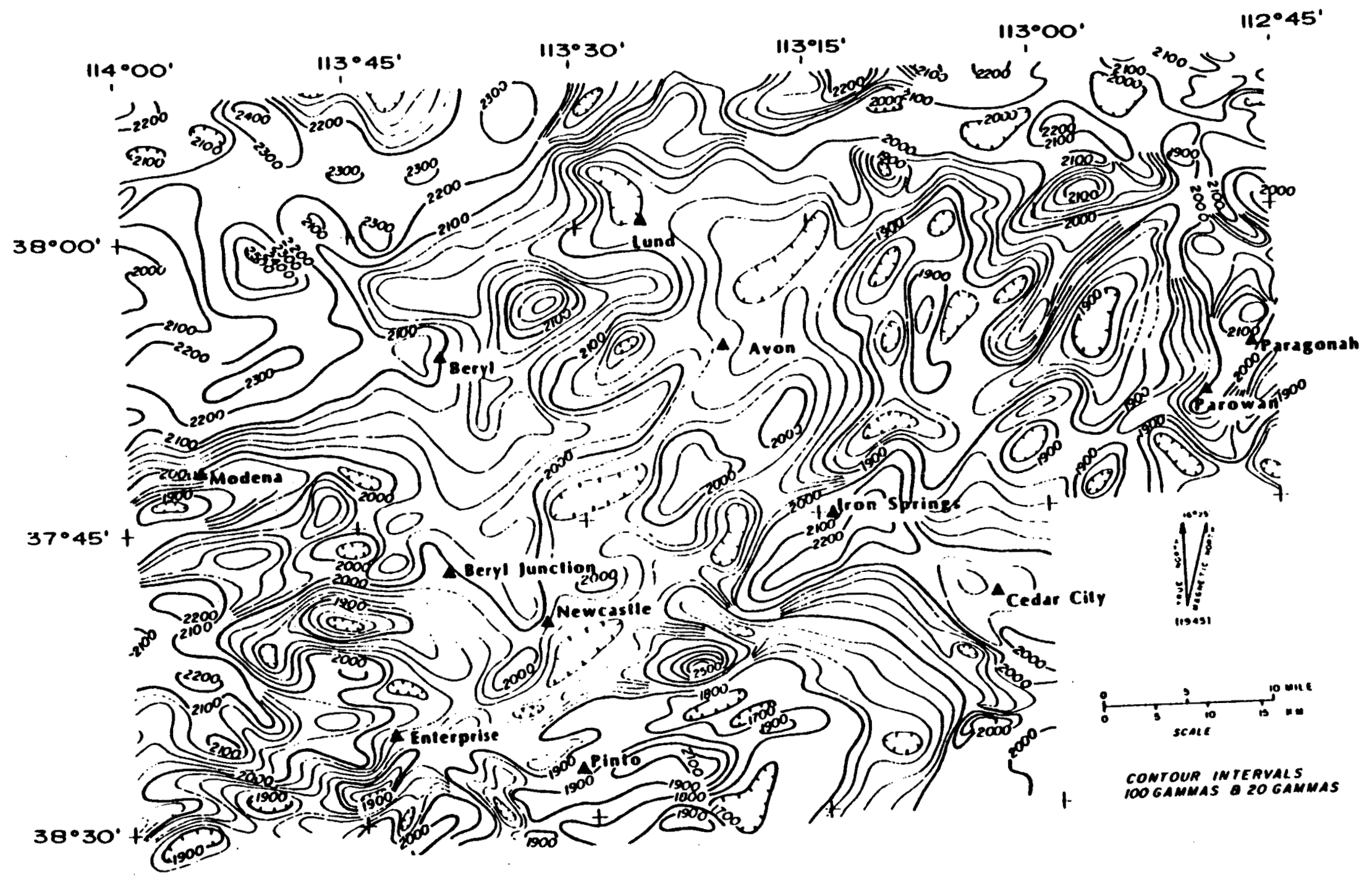

Figure 9. Aeromagnetic map of southwestern Utah (after $P \theta$ 1980). 
mentation, electrical interference from numerous high-tension power lines, and severe terrain noise in the acquired magnetic data, severely limited the interpretational utility of our magnetic data. Subsequently, we concentrated our efforts on a detailed gravity survey.

We later acquired the USX aeromagnetic data, which were in the form of contour maps, compiled from several different blocks of data. Unfortunately, one block was flown over the mountains east of Newcastle, and another block was flown over the valley area. A gap occurs between this coverage along the range front, the area critical to this study. Moreover, the data for these two blocks were evidently acquired by means of flights at two different elevations. Without reprocessing of the raw digital data, the contour maps are of limited use for studying detailed subsurface structure relative to the Antelope Range fault. We therefore made no attempt to interpret the USX maps.

\subsubsection{Gravity Survey}

\section{Instrumentation and Field Procedures}

Instruments used in the survey consisted of two La Coste and Romberg gravity meters with electronic readout (models G-264 and G-461). We established a local gravity base station at the edge of a field, approximately $15 \mathrm{~m}(50 \mathrm{ft})$ south from the Newcastle cemetery, about a mile west of the town center. At the Newcastle base station (referred to as 'GBS') and at all gravity stations established in the survey, we determined absolute gravity by means of a tie to the regional gravity base station in Enterprise, Utah established by Cook (and others, 1971).

We gathered gravity data along profiles established both normal and parallel to the range front (Figure 10). Data along lines SS (short) (Figure 11) and LL (long) (Figure 12) were acquired in November 1987, and data along lines A through L were acquired in September 1988. A total of 153 stations were initially occupied during 1987 and 240 more stations were occupied during 1988, for a total of 393 stations.

We established diurnal, or time, variation of the earth's gravity field along with instrument drift by taking daily, initial readings with each meter at GBS. Readings were repeated every three to five hours, and final readings taken at the end of each day.

Locations and elevations of GBS and all gravity points were established using a Pentax semi-total-station electronic theodolite with electronic distance meter (theodolite/EDM). Vertical control was established with a tie to a USGS bench mark (\#10JDB, elevation 5314 feet $[1620 \mathrm{~m}]$ ) located in Newcastle. Horizontal control was established by a tie to a section corner marker (corner of sections 19,20,29 and 30, township $36 \mathrm{~S}$ range $15 \mathrm{~W}$ in Iron County [USGS 7.5' quadrangle Newcastle]), where Utah Power and Light Company established state plane coordinates. 


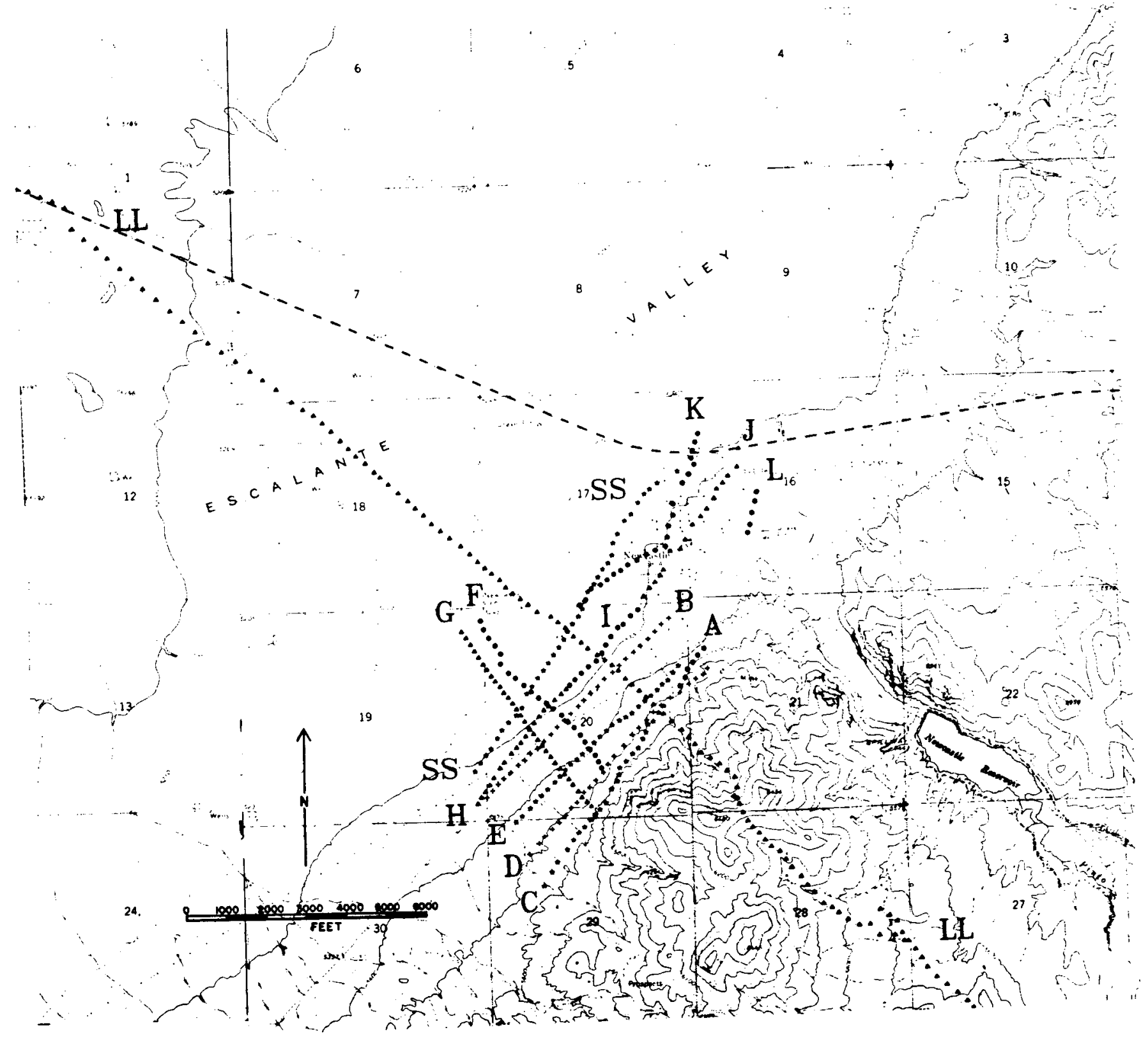
Figure 10. Gravlty survey station locatlons, lines SS, $U$, and A through $K$, plotted from Utah state-
plane coordinates (Appendbx C). Map base is the USGS Newcastle, Utah 7.5' quadrangle. 

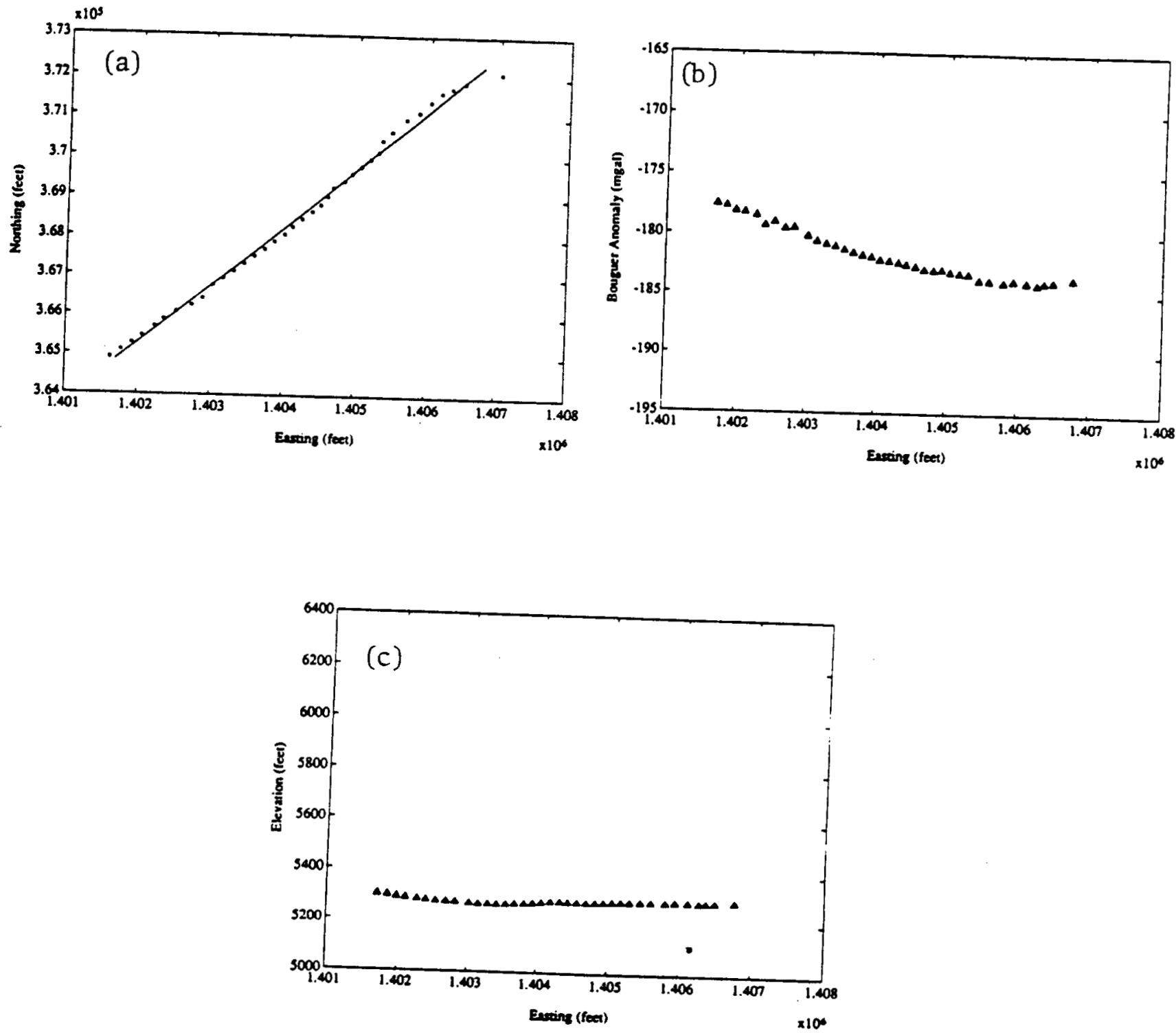

Figure 11. Station locations (a), Bouguer gravity (b), and station elevations (c) along line SS of
the detalled gravity survey. The horzontal scale the detalled gravity survey. The horlzontal scale is easting, Utah state-plane coordinates. 

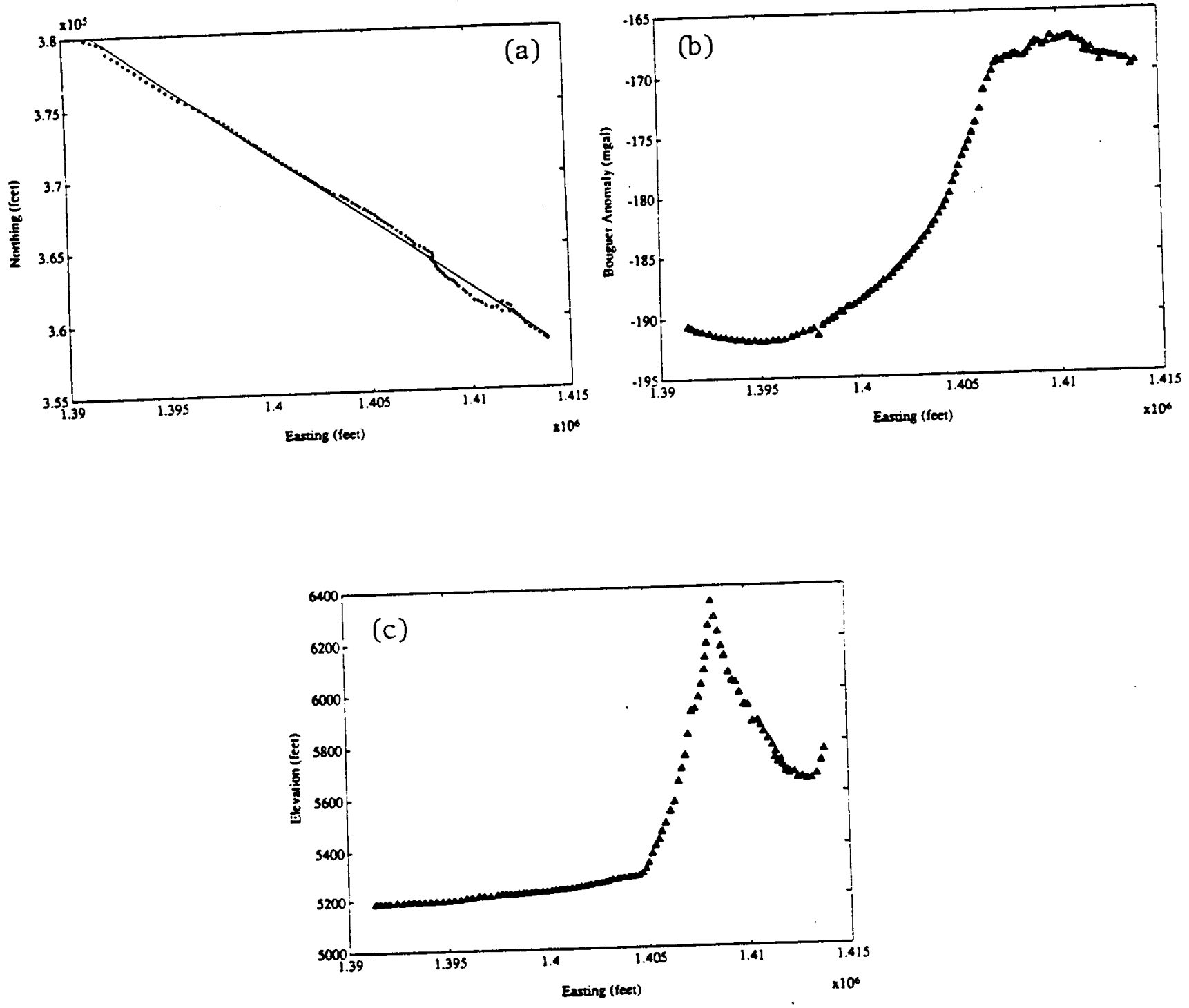

Figure 12. Station locations (a), Bouguer gravlty (b), and station elevations (c) along line $L L$ of the detalled gravity survey. The horizontal scale is easting, Utah state-plane coordinates. 


\section{Data Reduction}

After reducing theodolite and EDM data, an error analysis showed that survey base locations (points occupied by the theodolite/EDM) had only a few feet of horizontal error and less than one foot of vertical error throughout all survey bases -- an acceptable margin of error. Because we determined gravity station locations with foreshots only, we could not estimate gravity station location errors. The smoothness of variations in the gravity data, however, indicates that with the exception of only a few stations, surveying errors were minimal. Because of format requirements for various data reduction programs, all gravity station locations were assigned both latitude-longitude and Utah state plane coordinates.

For an overview of gravity data reduction the reader should refer to Telford (and others, 1976) or Dobrin and Savit (1988). Gravity data were first corrected for diurnal variations related to the solid earth tides, using a modified version of U.S. Geological Survey (USGS) program CON77. Gravity data were then corrected for instrument drift, using a modified version of USGS program LSADJ. Once we applied corrections for time variations, we then corrected for known conditions (earth's rotation, terrain) that give rise to spatial variations. The programs CON77 and LSADJ, originally written by R. Jachens, USGS, Menlo Park, California, were slightly modified for our purposes.

Because much of the region surrounding the project area is mountainous, terrain corrections were essential. We digitized USGS topography using the Newcastle 7.5' and relevant, surrounding quadrangle maps for applying two-step terrain corrections. Corrections for topography within a radius of $1.6 \mathrm{~km}$ ( $1 \mathrm{mi}$ ) about each station were applied using the digitized terrain data and a program, known as TRITER (Rupert, 1988), available from the Canadian Geological Survey. A density of $2400 \mathrm{~kg} \mathrm{~m}^{-3}$ (149.8 Ibs ft 3) was used for these inner zone corrections. Corrections for topography outside this zone, to a distance of $166.7 \mathrm{~km}$ (104 mi), were applied using USGS terrain data and USGS program BOUGUER (Godson, 1978; Plouff, 1977). We selected a density of 2400 $\mathrm{kg} \mathrm{m}^{-3}$ ( $149.8 \mathrm{lbs} \mathrm{ft}^{-3}$ ) for terrain corrections based upon previous studies of rock densities in this area (e.g., Pe, 1980).

The program BOUGUER was also used to compute the Bouguer anomaly by applying the latitude correction and the Bouguer and free air reductions (reduction to sea

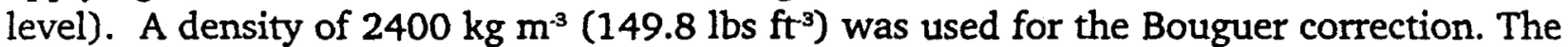
density of middle and lower crustal rocks must increase above this value, however, taking this into account yields what is essentially a constant correction for all stations, which would simply shift the baseline (the zero value) of our anomaly. Future studies could benefit from modification of the program BOUGUER so that a depth-dependent density could be used for the Bouguer correction. 
Since we had referenced all of our gravity readings to the regional gravity base station at Enterprise, Utah, where absolute gravity is known to be 979446.73 milligal (Cook and others, 1971) we were able to obtain observed gravity in an absolute sense at each station, and then calculate the complete Bouguer anomaly:

\section{$g_{\text {obs }}-g_{\text {theoretical }}$}

where $g_{o b s}$ is absolute gravity at each station, reduced to sea level using the free air and Bouguer reductions, with terrain corrections applied; and where $g_{\text {thereteical }}$ is theoretical gravity (1967 Gravity Formula) at sea level at the same latitude and longitude.

Principal facts of observations made during the 1987 and 1988 Newcastle gravity survey have been accumulated in four data files. Hard copies of these data files are contained in appendices $\mathrm{C}$ and $\mathrm{D}$.

Data files 87stn.dat and 88stn.dat contain eastings, northings, elevation (all in feet above sea level (1927 datum), latitude and longitude (decimal degrees) of all gravity stations from the 1987 and 1988 surveys.

Data files 1987.dat and 1988.dat contain the raw gravity data (dial readings, meter number, time and date). The dial readings are directly from the indicated La Coste \& Romberg gravity meters. Times are Mountain standard time for the 1987 survey and Mountain daylight savings time for the 1988 survey.

The presentation format of gravity results reflects the fact that the data were acquired mostly along profiles. Because profile lines were often slightly crooked, station locations were projected onto best-fit, least-squares lines. Gravity readings and station elevations were plotted as a function of the easting (Utah state-plane) coordinates.

The Bouguer anomaly and elevation along line SS and line LL are presented in Figures 11 and 12. Also presented in these figures is an xy-map of the projection adopted for each line. The Bouguer anomaly and elevation along lines $\mathrm{B}$ through $\mathrm{K}$ are displayed in Appendix D (figures D1 through D8). Data along lines $\mathrm{H}, \mathrm{I}$, and J were combined to form line HIJ. Because lines $A$ and $L$ are short, separate plots were not prepared. Gravimeter or survey data are in obvious error for about a dozen points. For completeness, however, these outliers remain in the gravity and location data.

\section{Interpretation}

The principal variations in Bouguer gravity in the Newcastle area are related to the Antelope Range fault. This is evident on line LL (Figure 12), and to a lesser extent on lines F and G (figures D5 and D6, Appendix D) as a large lateral gradient in gravity extending northwest-southeast, normal to the range front. 
The long profile (LL) across the Antelope Range fault shows no obvious variations that may relate to footwall or hanging-wall structures. Non-linearity in the profiles, however, cannot entirely account for a minor gravity inflection seen along line $G$. We interpret the inflection as due to either (1) excess mass present in the hanging wall (e.g., higher density alluvium near the fault plane, or small slide blocks at depth), or (2) a small step in the Antelope Range fault.

Relatively high-frequency variations in gravity occur along profiles near the range front fault. Two high-frequency variations seen on lines C and D (figures D2 and D3, Appendix D) are in all likelihood due to terrain effects (outcropping terrain) in the hanging wall. Apparent variation in gravity along line $\mathrm{K}$ is due to the marked deviation of this particular profile from a straight line (Figure D8, Appendix D). Starting at either end of the profile, the line deviates toward the range front, causing an apparent increase in gravity, and then away from the range front, causing an apparent decrease in gravity.

Moving from the southwest end of the survey area towards the northeast end, there is a consistent decrease in Bouguer gravity, which can be seen along line SS and lines B through E, and lines HIJ and $\mathrm{K}$. Although this variation is not evident in Pe's (1980) regional map (Figure 8), it possibly reflects the apparent splaying along the Antelope Range fault (map of Siders and others, 1989), or may indicate deepening of the Newcastle graben to the northeast.

Forward modeling of gravity data was adopted as a means of estimating the subsurface geometry near Newcastle. Dip and total offset along the Antelope Range fault are important parameters in the development of a conceptual model of the Newcastle hydrothermal system. In our modelling, we used a 2.5 dimensional routine written by J.H. Luetgert of the USGS, based on the algorithm of Cady (1980), and modified by C.M Schlinger for operation on UNIX-based and PC-type computers. The 2.5 D algorithm of Cady's uses constant density horizontal prisms, polygonal in cross-section, and invariant along strike. The strike length of the prisms is finite. The model discussed in this report is based on a model developed by Chisholm and Robertson (1988), with modifications to include the effect of the "Pinto graben" (Pe, 1980).

The final model adopted as a result of the forward modeling is illustrated in Figure 13. The model consists of a cross-section along the long line (LL) in Figure 12. This model includes the following features: 
1. The rock in which the structure sits has a density of $2525 \mathrm{~kg} \mathrm{~m}^{-3}(157.6 \mathrm{lbs}$ $\mathrm{ft}^{3}$ ), which is appropriate for the combination of Mesozoic sedimentary and igneous rocks present in the upper crust at this locality (Siders and others, 1989).

2. Sedimentary rocks of the Iron Springs and Claron formations along with volcanic rocks of the Isom formation and Quichapa group and various other unnamed units (rhyolite domes, volcaniclastic units, etc.) are represented by prisms with density of $2400 \mathrm{~kg} \mathrm{~m}^{-3}$ (149.8 $\left.\mathrm{lbs} \mathrm{ft}^{3}\right)$.

3. The Antelope Range fault was assigned a dip of $65^{\circ}$.

4. The Newcastle graben was represented by a combination of alluvial wedges.

5. A wedge of alluvium at depth, with a density of $2125 \mathrm{~kg} \mathrm{~m}^{-3}(132.7 \mathrm{lbs}$ $\mathrm{ft}^{3}$ ), thins basinward, and an overlying wedge, with a density of $1900 \mathrm{~kg}$ $\mathrm{m}^{-3}\left(118.6 \mathrm{lbs} \mathrm{ft}^{-3}\right)$, thickens basinward.

6. The small "Pinto graben" (Pe, 1980) is represented by a thin wedge of alluvial fan material with average density of $2000 \mathrm{~kg} \mathrm{~m}^{-3}\left(124.9 \mathrm{lbs} \mathrm{ft}^{3}\right)$, and a strike length of $4 \mathrm{~km}$.

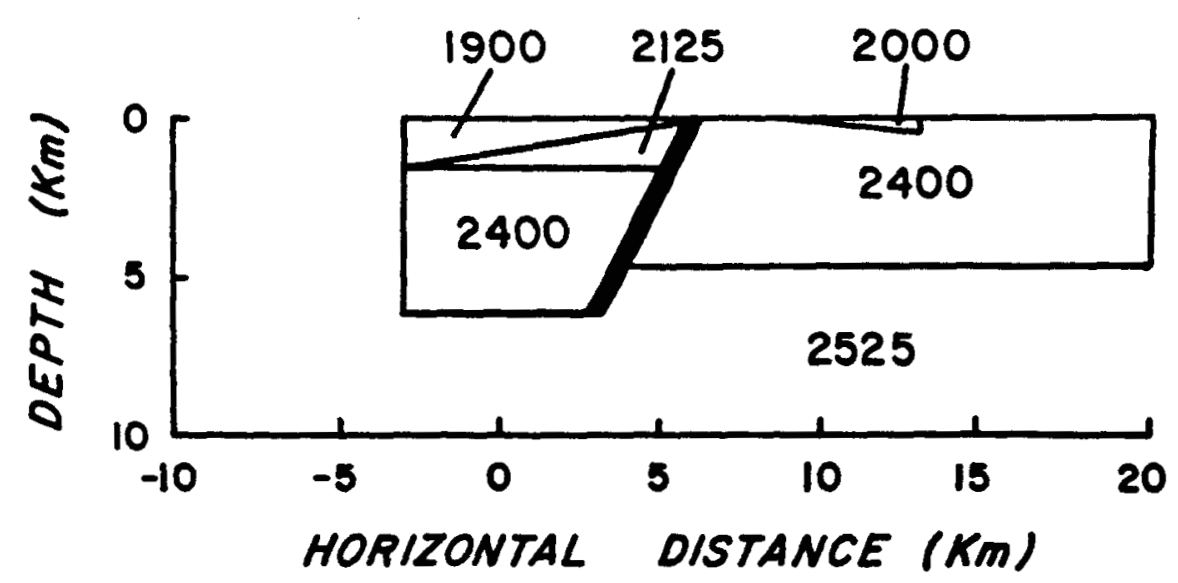

Figure 13. Model of subsurface structure in the vicinity of Newcastle. Densities shown are in $\mathrm{kg}$ $\mathrm{m}^{-3}$. With the exception of the shallow "Pinto graben" structure (density of $2000 \mathrm{~kg} \mathrm{~m}^{-3}$ ), the polygonal-cross-section structures that make up the model have strlke lengths of $20 \mathrm{~km}$ $(+10 \mathrm{~km})$. The Pinto 'graben' has a strlke length of $4 \mathrm{~km}(+2 \mathrm{~km})$. The $0 \mathrm{~km}$ mark corresponds to the NW end of gravity line LL (Figure 12). 
The strike length of the above model components, except for the Pinto graben, is $20 \mathrm{~km}(12.4 \mathrm{mi})$. The northwest edge of the Newcastle graben is not well defined and, therefore, not considered in the model. The upturn in the gravity anomaly on the northwest end of line LL, however, is evidence supporting the presence of a northwest boundary fault (Figure 12).

A comparison between the observed data and the calculated gravity anomaly from modeling are shown in Figure 14. Modeling by Chisholm and Robertson (1988) has shown that the effect of dip angle is moderate. Fault dips varying from 60 to 70 degrees yield model results that adequately fit the observed data. Our model uses an appropriate dip of 65 degrees along the Antelope Range fault with total offset of about $1.6 \mathrm{~km}$ (1 $\mathrm{mi})$. The model also suggests that the fault persists to at least $5 \mathrm{~km}(3 \mathrm{mi})$ depth.

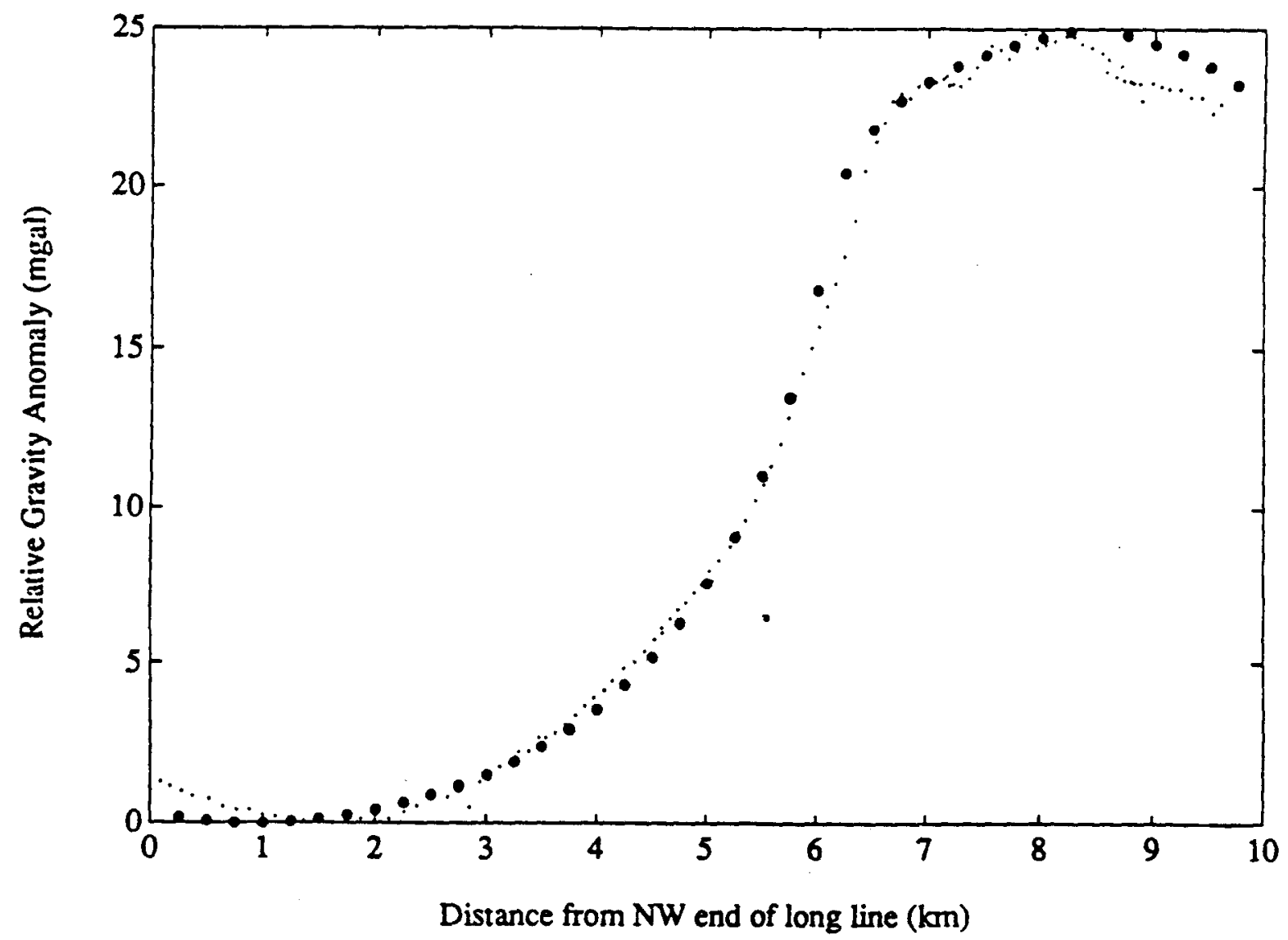

Figure 14. Comparison between observed data (small dots) and the gravity anomaly calculated (large dots) using the model in Figure 13. 
The results of the Newcastle gravity survey have shown the utility of gravity data for interpretation of subsurface structure in the Newcastle area. This is particularly true in this situation where other detailed geophysical information is unavailable. Other important results from this work include: (1) The Antelope Range fault dips about 65 degrees, and apparently persists to depths of at least $5 \mathrm{~km}$; and (2) Total offset along the Antelope Range Fault is about $1.6 \mathrm{~km}$ ( $1 \mathrm{mi}$ ), while gravity data suggest a deepening of the Newcastle graben to the northwest. High-resolution gravity surveys offer promise for geothermal site investigations, however, the non-uniqueness of gravity interpretation suggests that greater benefits will come from constrained interpretation in the presence other geophysical data.

The Newcastle gravity data were reduced following standard procedures that include the free air and Bouguer reductions. The observed data should eventually be reprocessed using a different scheme. Gravity observations should be corrected for latitude effects (arising due to the rotation of the earth and the equatorial bulge), and rather than reducing the observations to sea level, by means of the free air and Bouguer reductions, the observations should be interpreted without any further reductions. This means that once the latitude correction has been applied, the data should be modeled, using a two-step process. The first step would be to strip the effects of terrain in the area, accounting for terrain effects down to an arbitrary datum, of say $1500 \mathrm{~m}(5000 \mathrm{ft})$ (elevation). The gravitational effect of all the terrain within a certain distance, say 10 $\mathrm{km}(6.2 \mathrm{mi})$, of each station, would be calculated and removed. This would leave an observation of gravity corrected for terrain and latitude variation at some particular elevation, with corrected terrain and latitude. Following the removal of terrain effects, the effects of deep structure, including the normal fault, should be modeled using a scheme similar to the one used for this study.

Such a reduction scheme offers a more intuitive solution to the interpretation problem. No defined reductions such as the free air or Bouguer correction are introduced. These types of reductions are not corrections. They are defined procedures, nearly universally followed, which introduce not only an element of ambiguity, but also errors to the interpretation of gravity data acquired in areas of high topographic relief.

\subsection{Resistivity and Spontaneous Potential (SP) Surveys}

\subsubsection{Electrical Resistivity Survey}

An electrical resistivity survey was completed over much of the temperature anomaly by University of Utah Research Institute (UURI) and UGMS personnel in July 1989. The objectives of the survey were to (1) map the location of the rising thermal fluids and the distribution of the outflow plume, and (2) to document the electrical resistivity expression of the higher temperature portions of the geothermal system. Utah's two high-temperature geothermal systems, Roosevelt Hot Springs and Cove Fort- 
Sulphurdale, are both well expressed in resistivity data (Ross and others, 1982; Ross and Moore, 1985). The interpretation of these data has contributed to a better understanding of the resources.

Three high voltage electric power transmission lines which traverse northeasterly across the temperature anomaly restrict the locations available for conducting resistivity profiles. Figure 15 shows the location of the four resistivity profiles. The dipole-dipole array was chosen because it offers considerable flexibility in avoiding interference from grounded structures, simultaneously maps lateral and vertical resistivity changes, and because it can map subsurface bodies with a higher spatial resolution than other arrays. A dipole length of $152 \mathrm{~m}(500 \mathrm{ft})$ was selected as the best compromise for spatial resolutions from the surface to depths of $305 \mathrm{~m}(1000 \mathrm{ft})$ and for adequate lateral coverage.

The contoured apparent resistivity data for the third separation (Figure 15) indicates the net effect of resistivities from the surface to a depth of approximately one dipole length, i.e. $152 \mathrm{~m}$ (500 ft). Apparent resistivities of 4-10 ohm-m were recorded on the northwest portions of Lines 2 and 3, and from Stations 3-4 SW on Line 1. This area includes the higher temperatures observed in shallow temperature holes, which are believed to arise from a plume of low resistivity thermal waters.

A detailed numerical model interpretation of these data (Ross and others, in prep.) provides additional detail on the probable source of the thermal fluids from which this plume originates. Figure 16 illustrates a numerical model solution for Line 2. A low resistivity zone extends to depth near Station $1 \mathrm{SE}$, approaches the surface, and extends laterally to the northwest. The depth to the conductive layer, north of Station $2 \mathrm{NW}$, is modeled as approximately $45 \mathrm{~m}(152 \mathrm{ft})$. The sharp resistivity contrasts between Station 1 and Station 2 SE are suggestive of a buried fault, apparently dipping to the northwest.

The $4 \mathrm{ohm}-\mathrm{m}$ resistivity assigned to the thermal plume is consistent with low resistivity zones modeled for Roosevelt Hot Springs and Cove Fort-Sulphurdale, and requires low resistivity fluids (about $1 \mathrm{ohm}-\mathrm{m}$ ) and fairly high (20-40 percent) porosities in the alluvium or volcanics. The presence of substantial amounts of clay minerals would decrease the porosity or increase the fluid resistivity needed to account for the $4 \mathrm{ohm}$ m body.

Low resistivity zones indicating probable conduits for rising thermal fluids and outflow plumes were determined through numerical models for Lines 1,2 , and 3 , and are indicated on Figure 15. The lowest resistivities modeled for Line 4 were $10 \mathrm{ohm}$ $\mathrm{m}$. These occur north of Station $\mathbf{5} \mathrm{NW}$ and could represent slightly saline fluids at depths of approximately 500 feet. 


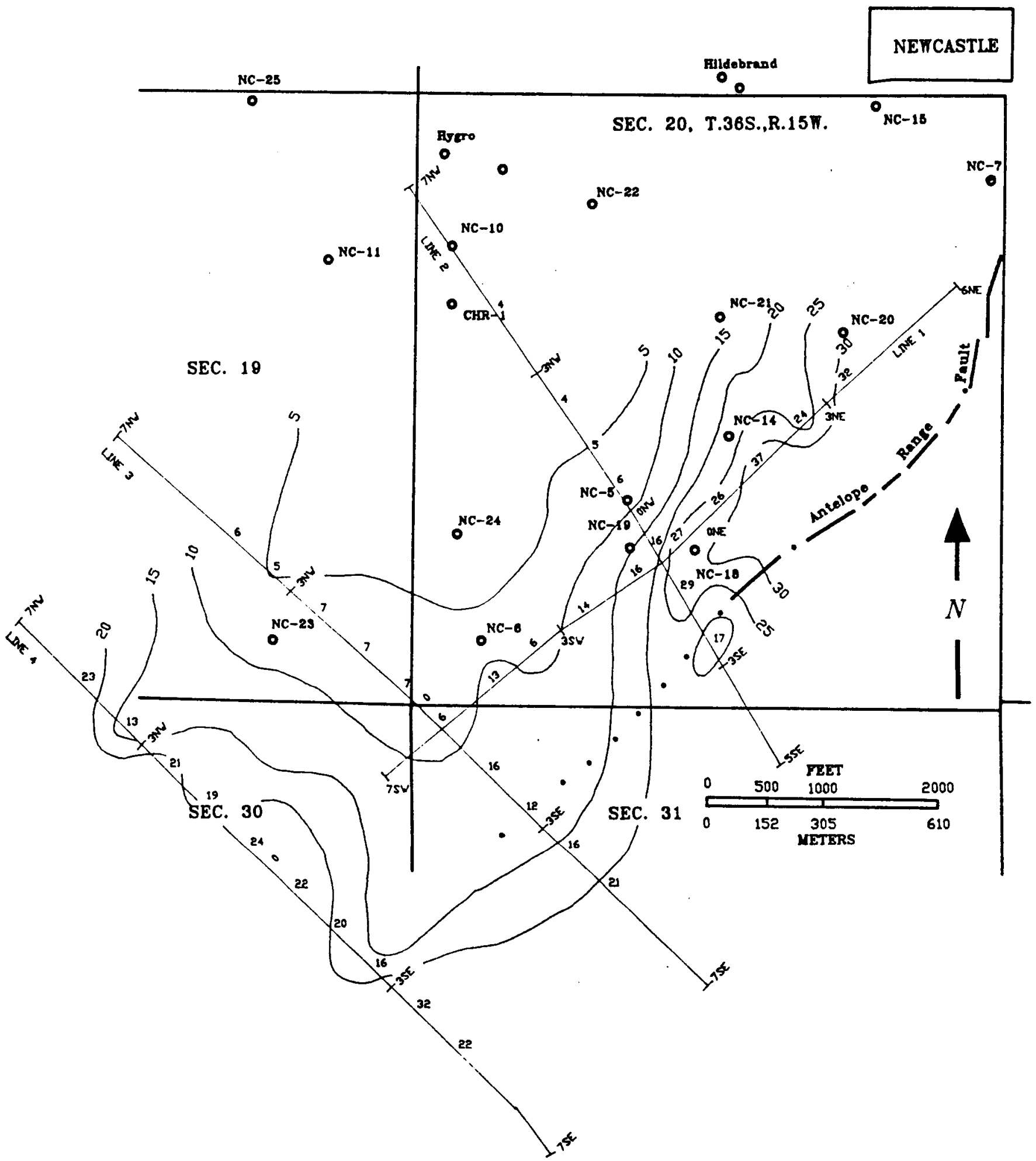

Figure 15. Contoured apparent resistivity for $3^{\text {rd }}$ separation. Contour Interval is 5 ohm-m. 

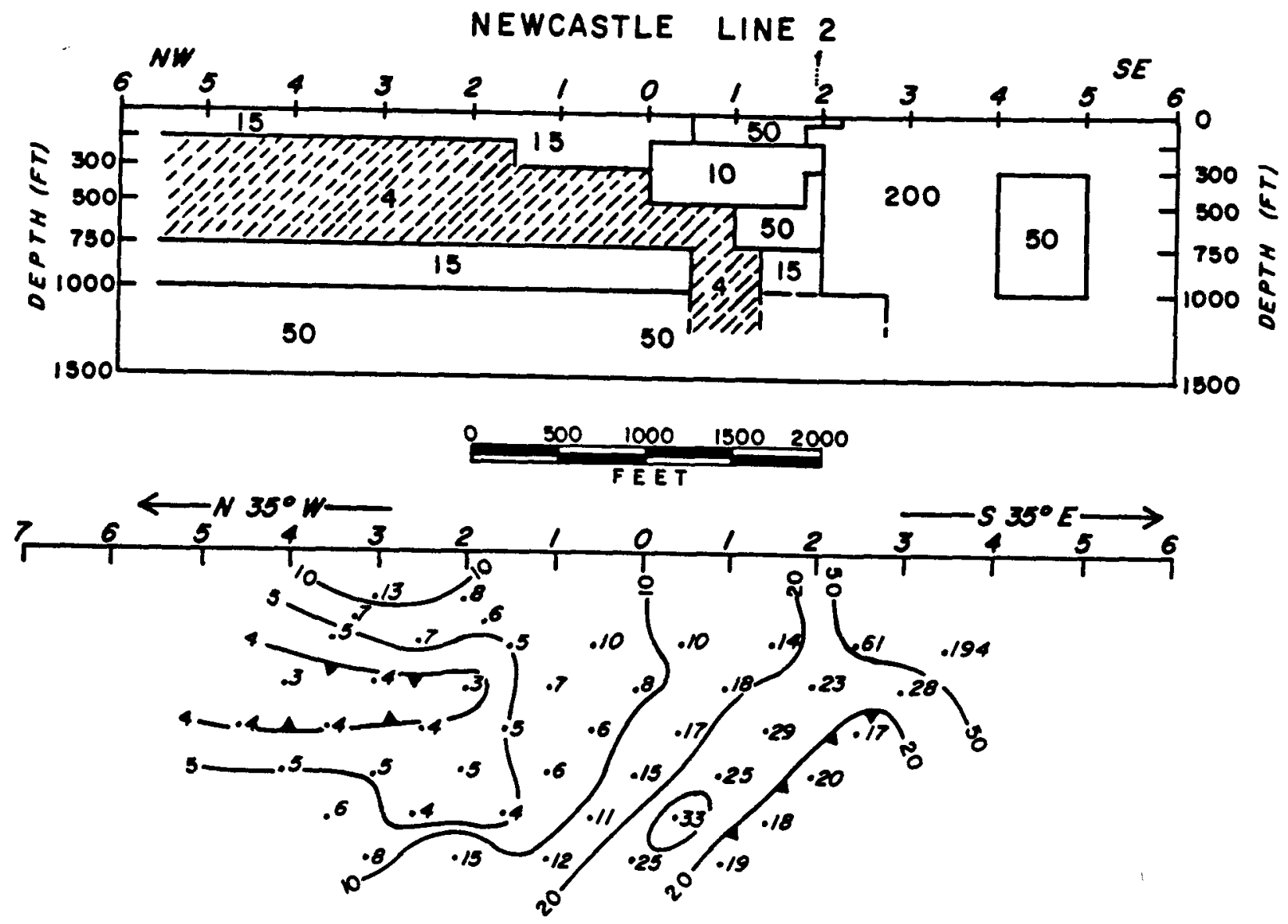

Figure 16. Numerical model solution for resistivity line 2. Hatched pattern denotes 4 ohm-m resistivity zone assigned to the upwelling thermal plume.

The dipole-dipole resistivity data have clearly mapped the thermal plume at Newcastle and have probably defined the principal structures, on Lines 2 and 3, along which the thermal fluids may be rising.

\section{$\underline{3.2 .1 \text { SP Survey }}$}

A spontaneous-potential (self-potential, or SP) survey was also completed at the Newcastle thermal area in November 1989 (Ross and others, in prep.). This survey identified a near circular $(150 \mathrm{~m}$, or $500 \mathrm{ft}$ diameter) 108 millivolt low nearly coincident with the low resistivity zone at Station 0-1 SE on Line 2 (Figure 17). No similar anomaly was noted on Line 3, perhaps indicating that the zone on Line 3 is altered and fluid

bearing but sealed, while the zone on Line 2 is open and a primary upflow zone for the Newcastle thermal water plume. A smaller, 30 millivolt low was observed which could indicate a minor zone of leakage along the Antelope Range fault. 


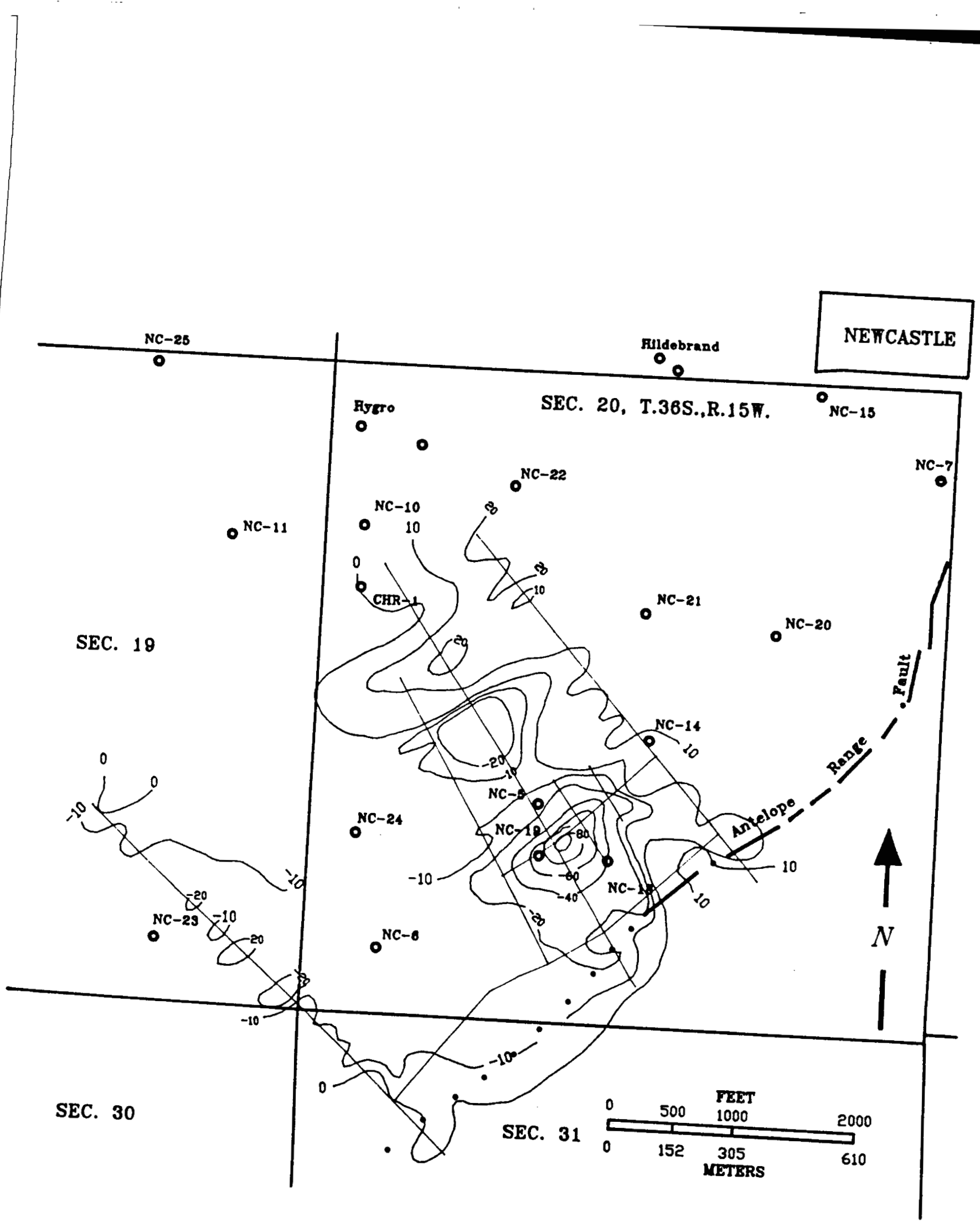

Figure 17. Contour map of spontaneous potential (SP) data. 


\subsection{SOIL-GAS GEOCHEMICAL INVESTIGATIONS}

\subsection{Soil-Mercury Survey}

Evidence of a linkage between mercury occurrences and hot spring activity has been previously documented. Areas of economic mercury occurrences, although not usually located near present day hot springs, exhibit evidence of past geothermal activity. Areas of present geothermal activity that have been mined for mercury in the past include Ngawha, New Zealand; Skaggs Springs, Sulfur Bank, Wilbur Springs and Coso Hot Springs, California; and Steamboat Springs, Nevada. In addition, mercury minerals (cinnabar and metacinnabar) have been noted to be depositing in some hot springs such as at Sulfur Bank and Amedee Springs, California; Steamboat Springs, Nevada; Boiling Springs, Idaho (Weissberg and others, 1979, p. 757).

Detailed mercury surveys by Parry, Benson and Miller (1976) and by Capuano and Bamford (1978) have also shown that mercury anomalies are associated with faults in close proximity to near-surface thermal activity. Capuano and Bamford (1978), using a technique of soil-sampling and analysis on gold film, noted that at Roosevelt Hot Springs mercury values dropped to "background concentrations" in nearby locations with little or no indication of subsurface thermal activity.

During the process of hydrothermal alteration of sulfides and other minerals containing $\mathrm{Hg}$ in trace amounts, $\mathrm{Hg}$ is released in the $2+$ valence state. $\mathrm{Hg}^{+2}$ can then be reduced by $\mathrm{Fe}^{+2}$ or by organic material to $\mathrm{Hg}^{+}$or $\mathrm{Hg}^{\circ}$. The result is a net production of $\mathrm{Hg}^{\circ}$ (Klusman and Landress, 1978). High vapor pressure of $\mathrm{Hg}^{\circ}$ makes it an extremely mobile, volatile component in a gas-water system. Elevated temperatures encountered in and near a geothermal system serve to increase this mobility resulting in the migration of $\mathrm{Hg}$ upward and away from a geothermal reservoir. The overall result is that soils in geothermal areas tend to become $\mathrm{Hg}$-enriched by trapping vapor phase $\mathrm{Hg}$ onto clay surfaces and within organic materials.

Because of the apparent success of these types of surveys, we performed a soilmercury survey at Newcastle across the area of suspected geothermal upflow. Some 110 soil samples were taken on a sample grid of 200 feet by 500 feet within the geothermal area. Five additional samples were also collected away from the geothermal area in an effort to determine background values. The samples were then delivered to the Earth Science Laboratory -- University of Utah Research Institute for analyses using a Model 301 Gold Film Mercury Detector (Jerome Instrument Corp., Jerome, Arizona). By this method, a weighed sample of soil is heated with a propane torch to a temperature of over $600^{\circ} \mathrm{C}$. Mercury vapor is released and collected onto a gold film. The quantity of mercury is measured by the change in electrical resistance of the gold film (R. Kroneman, pers. comm.). 
The mean and standard deviation for the sample set taken from the geothermal area, reported in parts per billion were 30 and 10 respectively. The general distribution of sample points falling within the 4th quartile $(\geq 40 \mathrm{ppb})$ forms irregular patterns near the range front (Figure 18). One area is within close proximity of drill holes NC-18 and NC-19, possibly corresponding to thermal and geophysical anomalies in this area. Another area lies a short distance to the northeast along the surface trace of the Antelope Range fault. The mean and standard deviation for the sample set taken away from the geothermal area were 26 and 8 respectively.

The results of the soil-mercury survey were disappointing with respect to utilizing this method as an exploration tool for blind hydrothermal systems such as at Newcastle. We expected to see very distinct soil-mercury anomalies corresponding to zones of hot water. Instead we observed only subtle variations in the concentration of soil mercury. The outcome does suggest, however, that the use of this method (soil sampling rather than gas sampling) in areas lacking of a surface geothermal expression, should be looked upon with a degree of caution. Other methods that sample larger volumes of soil-gas, such as described by Jensen and Qidwai (no date) might prove more applicable for studying buried hydrothermal systems.

\subsection{Radon Survey}

Radon is a ubiquitous, chemically inert, radioactive nobel gas. It is soluble in cold water with solubility decreasing with increasing temperature, and can migrate freely through porous and fractured media. Radon occurs in nature principally as three isotopes -- $\mathrm{Rn}^{219}, \mathrm{Rn}^{220}$, and $\mathrm{Rn}^{222}$-- produced as part of the $\mathrm{U}^{235}, \mathrm{Th}^{232}$, and $\mathrm{U}^{238}$ decay series, respectively. Because of duration of half-life, $U^{238}$ is the most important of the three parent elements in the production of radon. $\mathrm{Rn}^{222}$ has a half-life of 3.825 days, while the other isotopes have half-lives of less than one minute. Because of its relative abundance and a half-life much longer than the other isotopes, $\mathrm{Rn}^{222}$ is used often as a geologic tracer in geothermal systems, and is normally the isotope referred to in "radon" studies. $\mathrm{Rn}^{219}$ is referred to as actinon, and $\mathrm{Rn}^{220}$ is often called thoron (Nielson, 1978, p. 6).

The principal link between radon gas and geothermal systems relates primarily to geologic structures that control those systems -- usually a major fault, or system of faults, which act as conduits for the upward migration of thermal fluid. Radon is steadily generated by radioactive elements found in geologic materials, and migrates through the subsurface by diffusion and transport processes. Because of its relative short half-life (3.825 days), radon anomalies typically mark the approximate location of their source.

Radon concentration in soil can vary up to four orders of magnitude. These wide variations occur because of the wide range in the rate in which radon can be generated from its sources. Variations are a result of numerous factors including rates of fluid flow, 


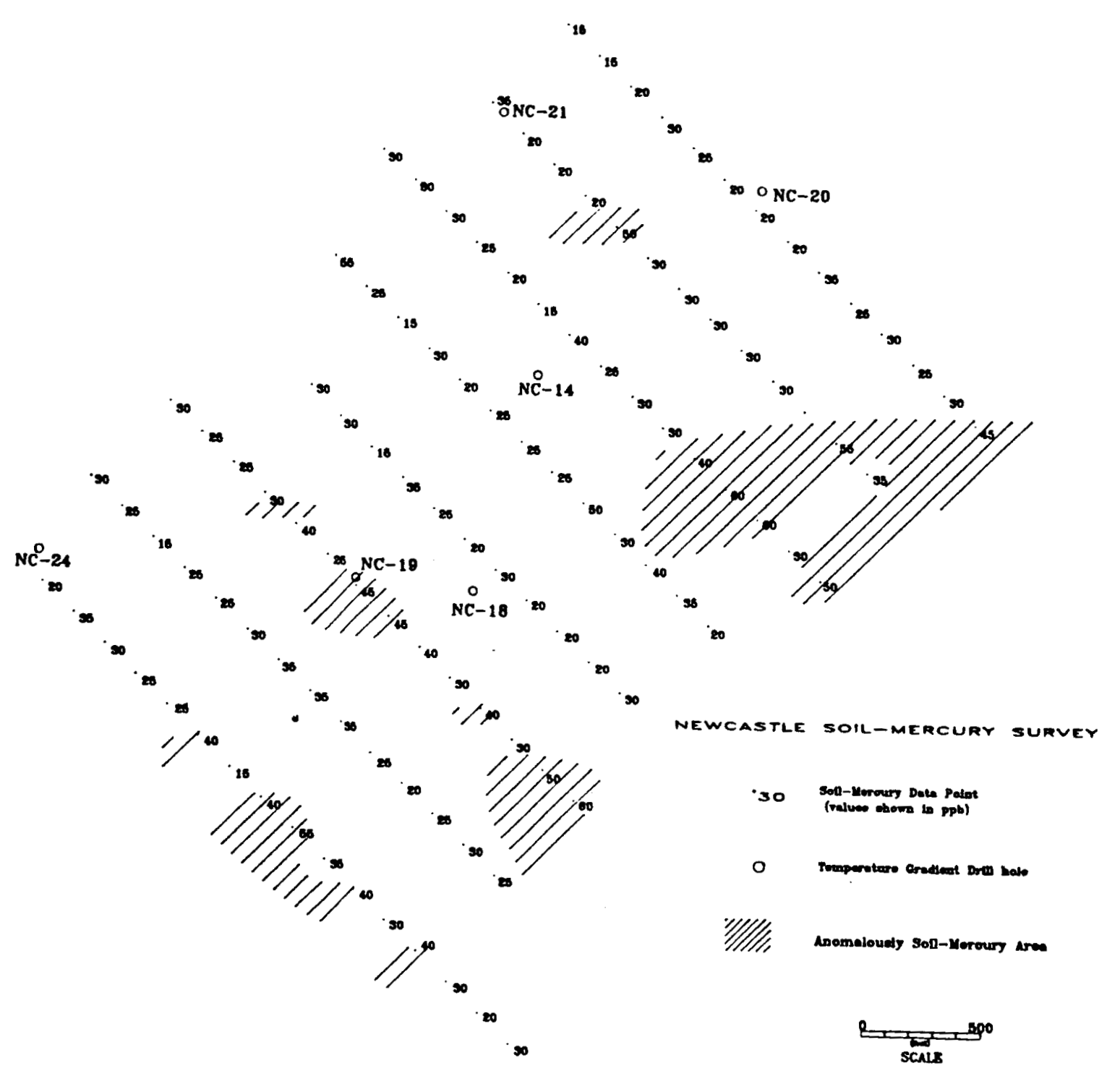

Figure 18. Map showing soll-mercury sample locations, sample values (in ppb), and areas of 40 ppb or greater of mercury
concentrations. 
secular equilibrium within the $\mathrm{U}^{238}$ decay chain, climatic conditions, and local geology. Because of these variables, which affect concentration, radon surveys cannot be used in a quantitative way. Their use, however, as an exploration tool to detect faults and geothermal upflow has been documented (Nielson, D.L., 1978).

Radon is measured indirectly by detection of alpha particles emitted as part of natural radioactive decay. The detection method normally used is direct exposure of alpha track material to ambient radon -- a film of alpha track material (in a detector) is placed into a cup, which is filtered to remove the progeny. The cup is placed at the desired location and left over a period of time. Radon diffuses into the upside-down cup, where it decays. The alpha emissions from the decay leave microscopic damage along the track left by each alpha particle. After exposure for the desired period of time, the film is removed from the cup and etched in an acidic or basic solution. The exposure of the detectors is determined and standardized for the amount of exposure time.

The objective of our study at Newcastle was to observe radon concentrations across the mapped thermal anomaly and the Antelope Range fault -- thought to be a major factor controlling the geothermal system. We measured radon using alpha particle detectors. The detector system consisted of an alpha-sensitive dosimeter attached to the inside of a plastic cup. The cups were placed in eight-inch diameter holes 20 to 24 inches beneath ground level. The holes were lined with PCP pipe and sealed at the top. The detectors were left at the bottom of the holes for about six weeks. At the end of the exposure time the detectors were recovered and returned to the marketing laboratory for analysis.

Our survey utilized 48 alpha radon detectors, placed along three transverse lines, laid out at right angles to the Antelope Range fault and crossing the thermal anomaly (Figure 19). A fourth, short line was also laid out across the Antelope Range fault a distance south from the thermal anomaly. Detectors were normally placed at intervals of $60 \mathrm{~m}(200 \mathrm{ft})$ along each line, with closer spacings of $15 \mathrm{~m}(50 \mathrm{ft})$ used near the trace of the Antelope Range fault.

The mean radon concentration of the survey was 354 pico-curies per liter $(\mathrm{Pc} / \mathrm{L})$. Figure 19 shows the survey lines and the area(s) of anomalous radon concentration. Along the margins of the thermal anomaly, radon anomalies appear more closely associated with the trace of the Antelope Range fault. Within the thermal anomaly, however, radon anomalies appear to be displaced westward from the mapped fault trace, possibly reflecting movement of fluid in the subsurface.

The southwest end of traverse line 1 (figures 19 and 20a) crosses the Antelope Range fault and exhibits anomalous radon flux over the fault. Moving along the traverse to the northwest, radon concentrations appear to drop to background levels. Radon concentrations along traverse line 2 (Figure 20b) are generally above background. In 


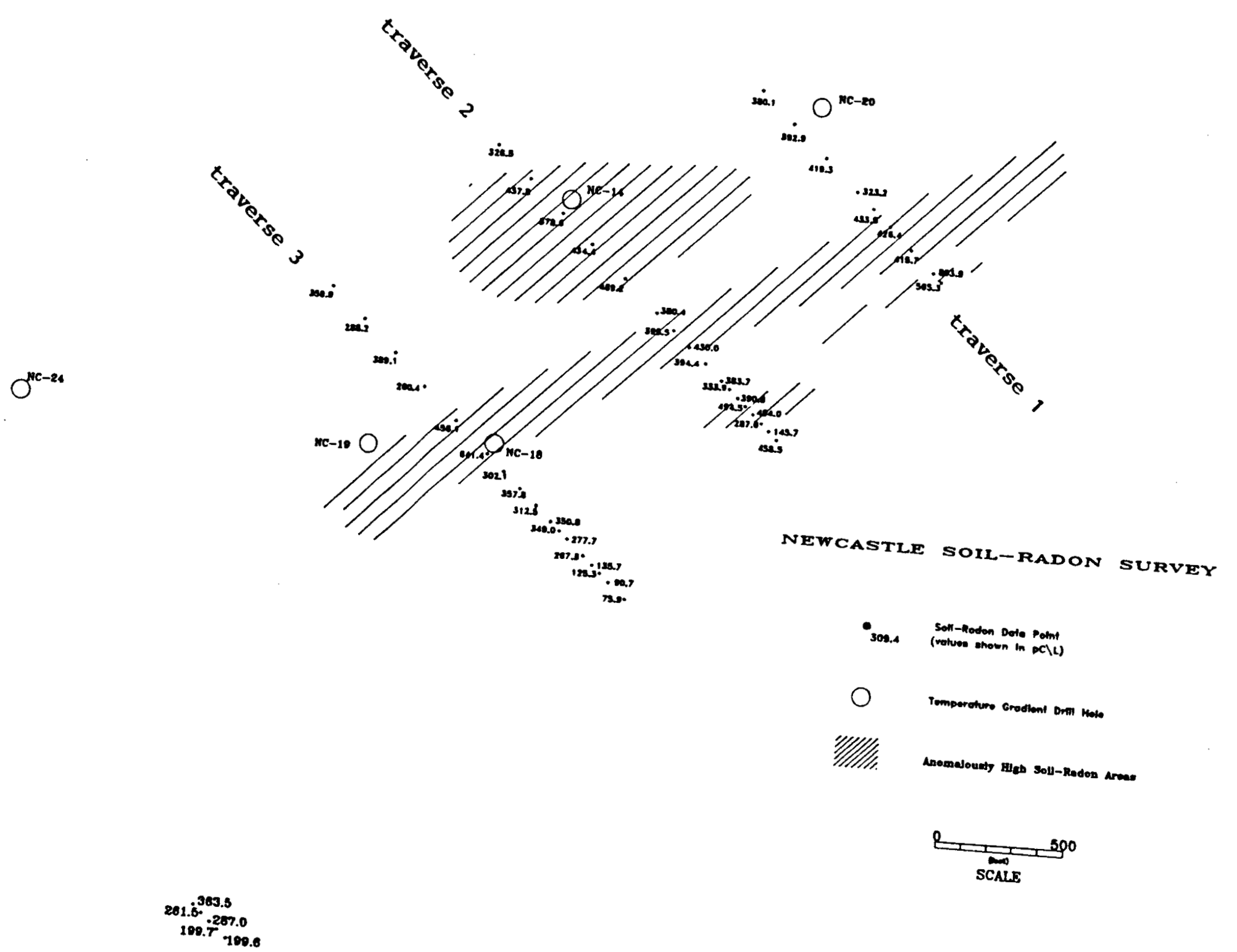

Figure 19. Map showing location of radon traverse lines, sample points, and radon concentrations. 

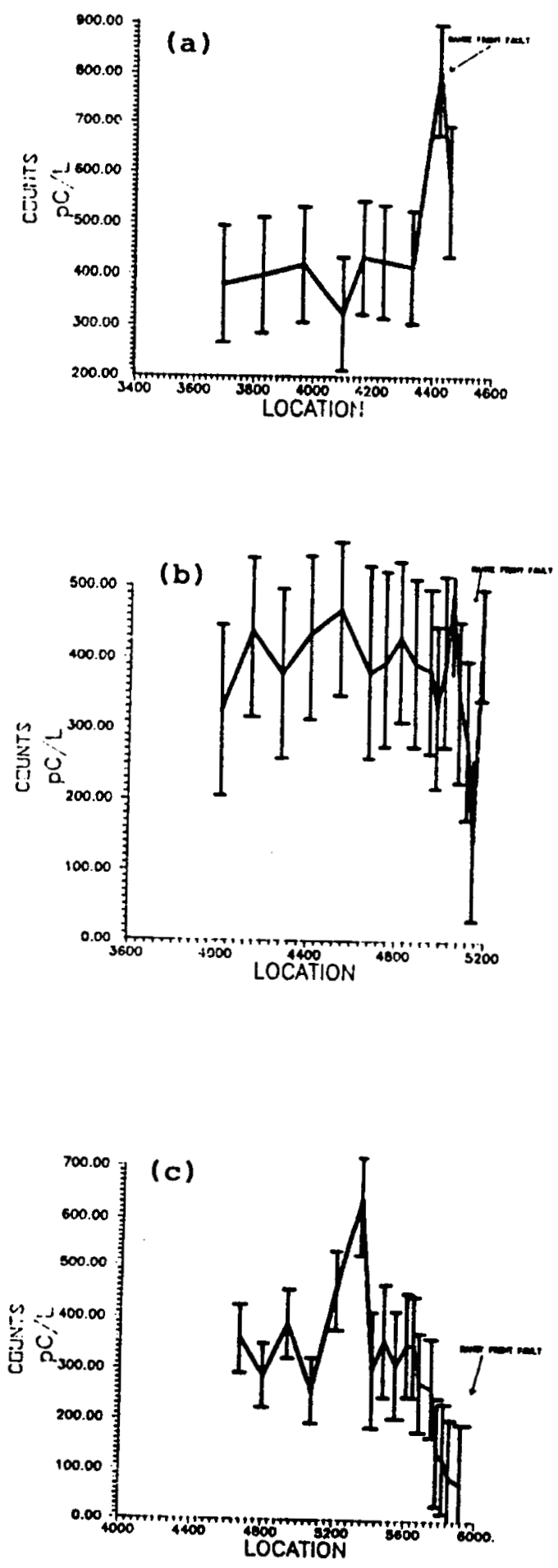

Figure 20. Radon traverses 1, 2, and 3 indlcated as a, b, and c respectively. Error bars represent standard deviation of the sample population. 
contrast to line one, however, anomalously low radon values are seen along the southeast end of line 2 where it crosses the surface trace of the Antelope Range fault. In similar fashion to line 2, traverse line 3 (Figure 20c) shows relatively low radon flux over the Antelope Range fault. Radon values then increase gradually to the northwest, and show some of the highest readings throughout the survey.

One interpretation of the radon pattern seen in the soil is that radon is likely moving upward in association with the Antelope Range fault and the geothermal fluid. In the area where the geothermal fluid moves closest to the surface and begins to flow down the hydraulic gradient, radon becomes displaced to the northwest, away from the fault. The soil-gas expression of this situation then is a negative anomaly over the trace of the fault and relatively high radon values across the outflow portion of the system. 


\subsection{A CONCEPTUAL MODEL FOR FLUID FLOW AND HEAT TRANSPORT IN THE NEWCASTLE GEOTHERMAL SYSTEM}

\subsection{Background}

Drilling and completion of the Christiansen Brothers irrigation well near Newcastle, Utah revealed groundwater temperatures in excess of $100^{\circ} \mathrm{C}$ between depths of 60 and $152 \mathrm{~m}$. Subsequent measurements of groundwater temperature in water wells and geothermal exploration holes (Chapman and others, 1981; Clement, 1981; Mower, 1982; Rush, 1983; Mabey and Budding, 1987) indicates a $25 \mathrm{~km}^{2}$ (9.7 mi2) region where groundwater temperatures are elevated above the mean annual air temperature of $15^{\circ} \mathrm{C}$. Because hydrothermal phenomena such as hot springs or mud pots are absent, the Newcastle geothermal area is termed a blind geothermal system. Although reservoir temperatures in excess of $140^{\circ} \mathrm{C}\left(284^{\circ} \mathrm{F}\right)$ are predicted (Rush 1983), temperatures reached only $130^{\circ} \mathrm{C}\left(266^{\circ} \mathrm{F}\right)$ in a $912 \mathrm{~m}(2992 \mathrm{ft})$ geothermal exploration hole drilled a short distance from the Christian Brothers well. The presence of several geothermal prospects marked by thermal springs located on the rim of the Escalante Desert indicates that other blind geothermal systems may be present in the region (Rush, 1983). Exploration experience at Newcastle suggests, however, that the lack of surface expression of a geothermal resource and the apparent localization of elevated temperatures complicates the siting of geothermal exploration wells. Developing a better understanding of the Newcastle geothermal system is expected to aid in reassessing the potential of the Newcastle system and provide a framework for developing the strategies needed to explore for blind geothermal systems elsewhere in the Basin and Range Province.

Our working model of the inferred pathways for groundwater flow in blind geothermal systems similar to that found at Newcastle is shown in Figure 21. Groundwater recharge is presumed to become heated during circulation in this region of elevated heat flow (about $90 \mathrm{~mW} \mathrm{~m}^{-2}$ ). A zone of high-permeability, located at the contact between valley fill and bedrock, likely provides a preferred pathway for upflow and localized discharge of heated groundwater to the valley-fill deposits. Minerals precipitating within the valley-fill deposits may form a low-permeability seal that enhances upward groundwater flow at the bedrock-sediment interface. Heated groundwater discharged from the high-permeability zone may mix with the cool groundwater flowing in alluvial fan deposits found along the valley margin.

This section of our report outlines the results of a study designed to 1) obtain a better understanding of the factors controlling the localized thermal anomaly identified at Newcastle, 2) help refine the working model shown in Figure 21, and 3) provide guidelines for exploration and testing of blind geothermal systems that may exist in similar environments. The following tasks were performed to meet these objectives: 


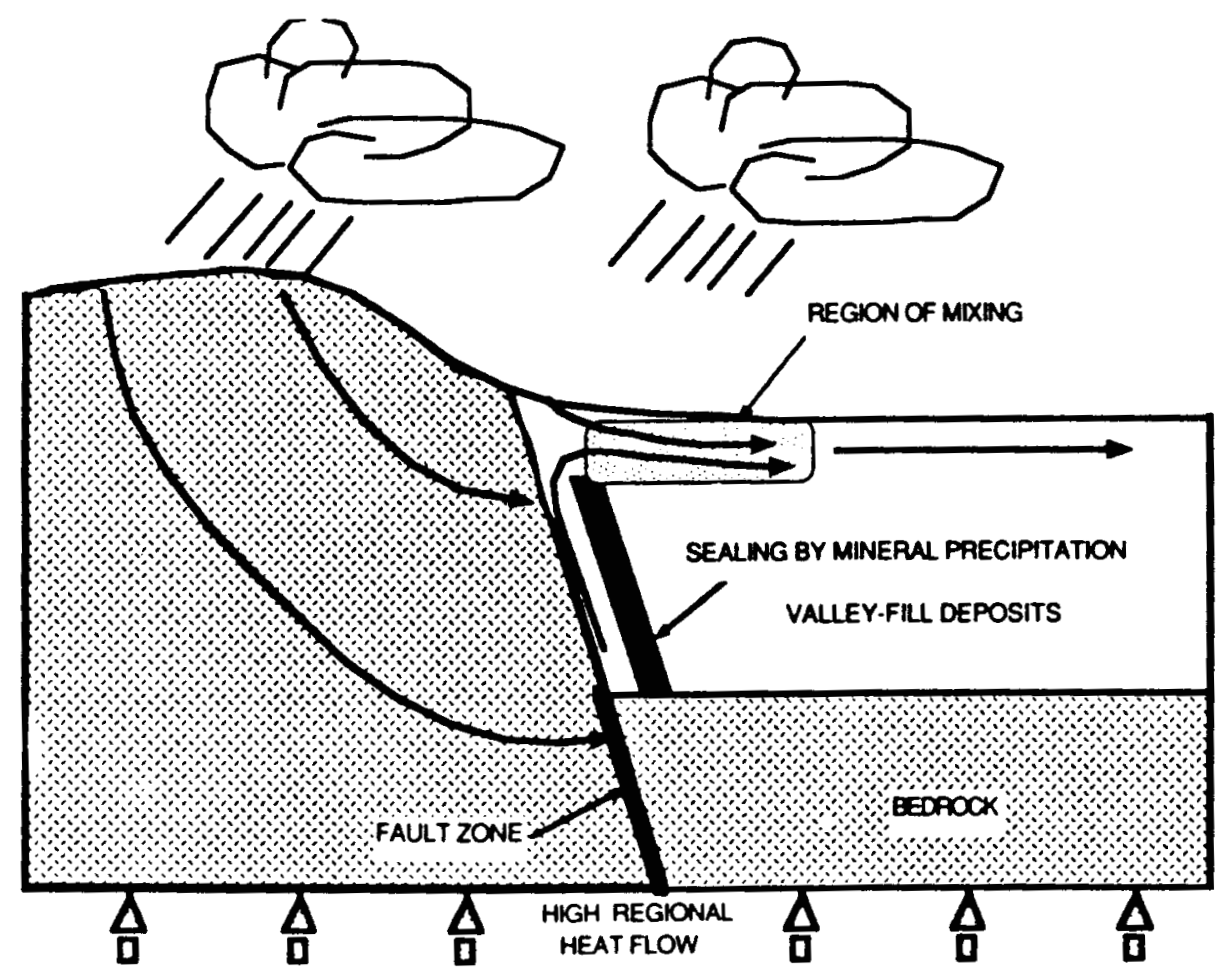

Figure 21. Working model for fluld flow and heat transfer In the hydrothermal system found at Newcastle, Utah.

1) Use existing data to characterize the Newcastle geothermal area and design a strategy for collecting additional thermal, hydrologic, and geochemical data.

2) Install thermal monitoring wells and collect a series of temperature-depth logs from these and existing wells to expand current understanding of the subsurface thermal regime and revise previous estimates of heat loss from the geothermal system.

3) Collect groundwater samples to perform the geochemical and stable isotope analyses needed to better understand the process of mixing of hot and cold groundwater at shallow depths.

4) Use the new and existing data to constrain numerical models of groundwater flow and heat transport in idealized versions for the Newcastle area.

5) Propose a most probable conceptual model for the Newcastle geothermal area that is consistent with field data and numerical modeling results. 


\subsection{The Newcastle Geothermal Area}

Figure 22 is a composite plot of temperature-depth profiles obtained by Rush (1977) from shallow wells in the vicinity of Newcastle (labelled NC-2 through 12 in Figure 23). Temperature-depth data and individual temperature-depth plots for these and subsequent wells are presented in Appendices $\mathrm{E}$ and $\mathrm{F}$, respectively. The profiles exhibit many features such as subnormal gradients, downward curvature, isothermal sections, and temperature reversals that are characteristic of many geothermal systems (Bodvarsson, 1973; Lachenbruch and others, 1976; Lachenbruch and Sass, 1978; Sass and Sammel, 1976; Sorey and others, 1978; Mase and others, 1978, 1979). These features are caused by fluid motion in recharge, discharge, and lateral flux regions, respectively, where a substantial quantity of heat is being transferred by moving groundwater. Only one site (NC-12, located $3 \mathrm{~km}$ northeast of Newcastle) has a subnormal gradient $\left(21^{\circ} \mathrm{C} \mathrm{km}^{-1}\right)$ indicative of a hydrologic recharge zone. The remaining ten sites have near-surface gradients that range from $89^{\circ} \mathrm{C} \mathrm{km}^{-1}$ to $1870^{\circ} \mathrm{C} \mathrm{km}^{-1}$. Whereas NC-2, 3, and 4 exhibit constant gradients, the temperature patterns at NC-6, 8, 9, and 11 become isothermal, or reverse, between 75 and $100 \mathrm{~m}$ (246 and $328 \mathrm{ft}$ ). These data lead Chapman (and others, 1981) to suggest that heated groundwater is flowing laterally in a more permeable zone located at a depth of 75 to $100 \mathrm{~m}$ ( 246 to $328 \mathrm{ft}$ ). Heat is presumed to be released from this region of elevated temperature by conduction through the surrounding lower-temperature material and by mixing with cooler groundwater.

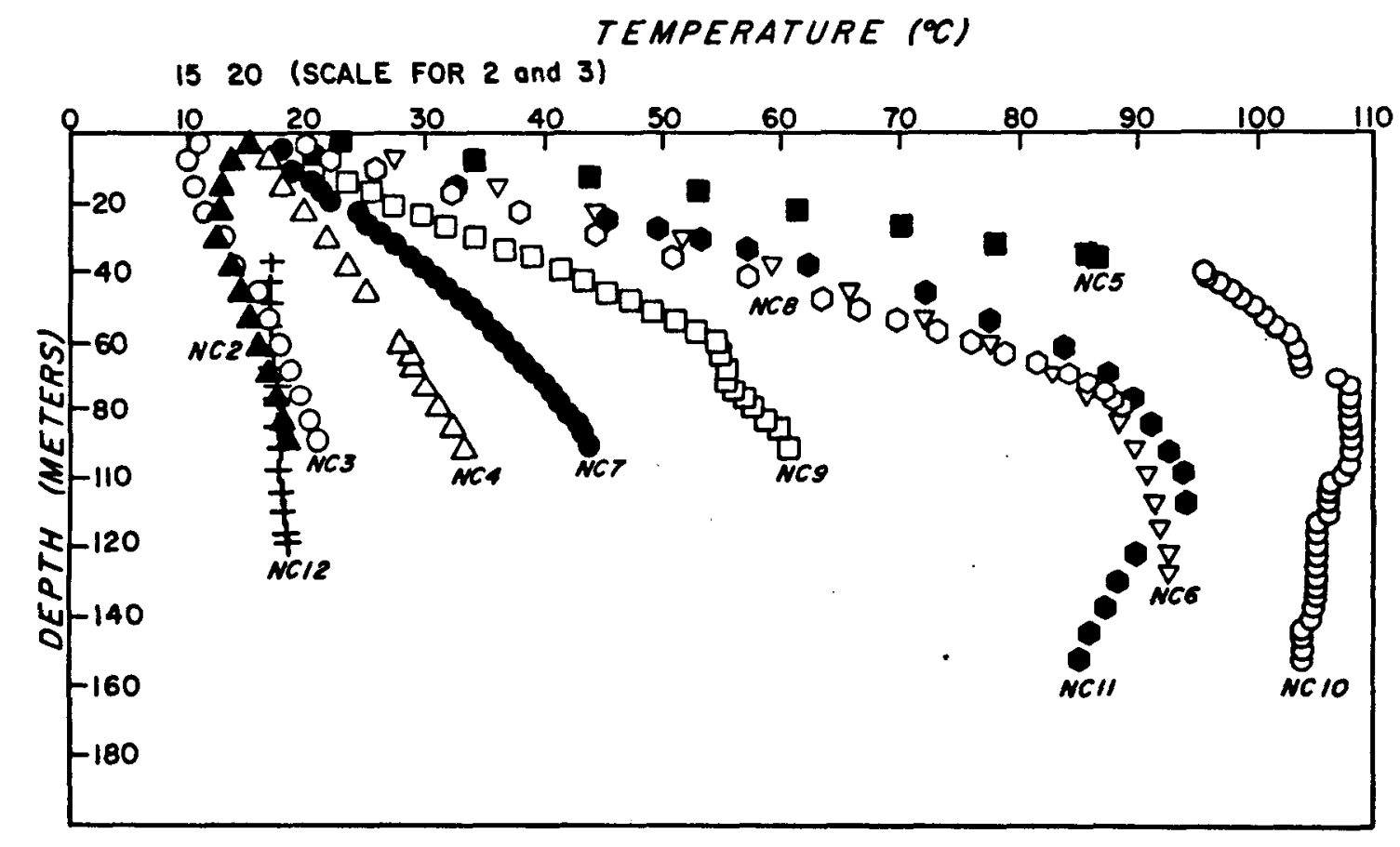

Figure 22. Temperature-Depth plots for pre-existing wells NC-2 through 12. From Clement (1981) and Chapman and others, 1981. 


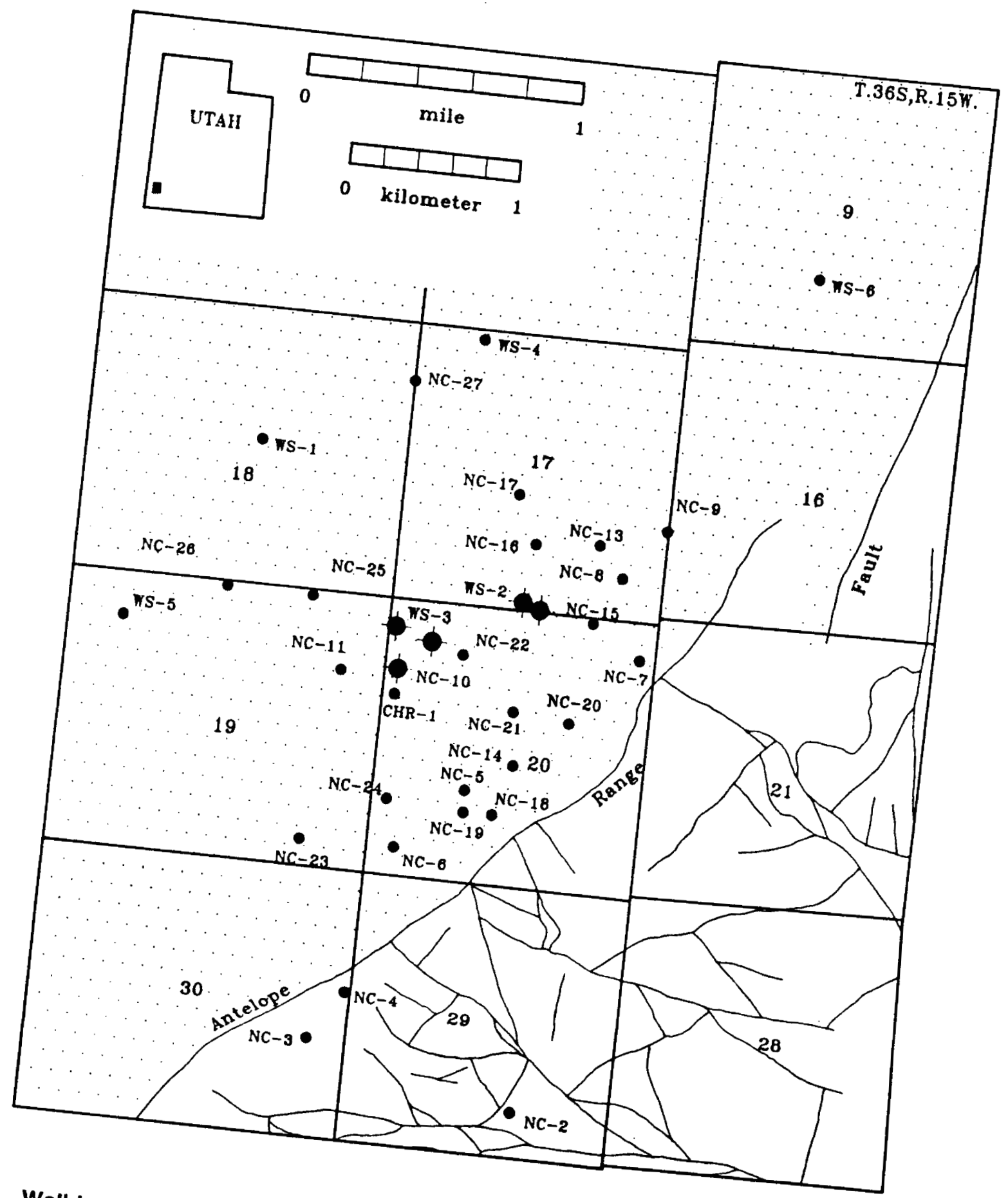
drilled prior to this study (NC-2 throundicate: small solld circles $=$ thermal gradlent holos sampled for water allable or drllled for thls -11 , Unlon Geothermal well Gradient holes supply wells drllled analyses (WS-1, WS-4, WS -5 W (NC-13 through NC-27 CHR-1); thermal (Hildebrand), WS-3 for greenhouse space heating, WS); large solld circli irrigation wells (Troy Hygro). 


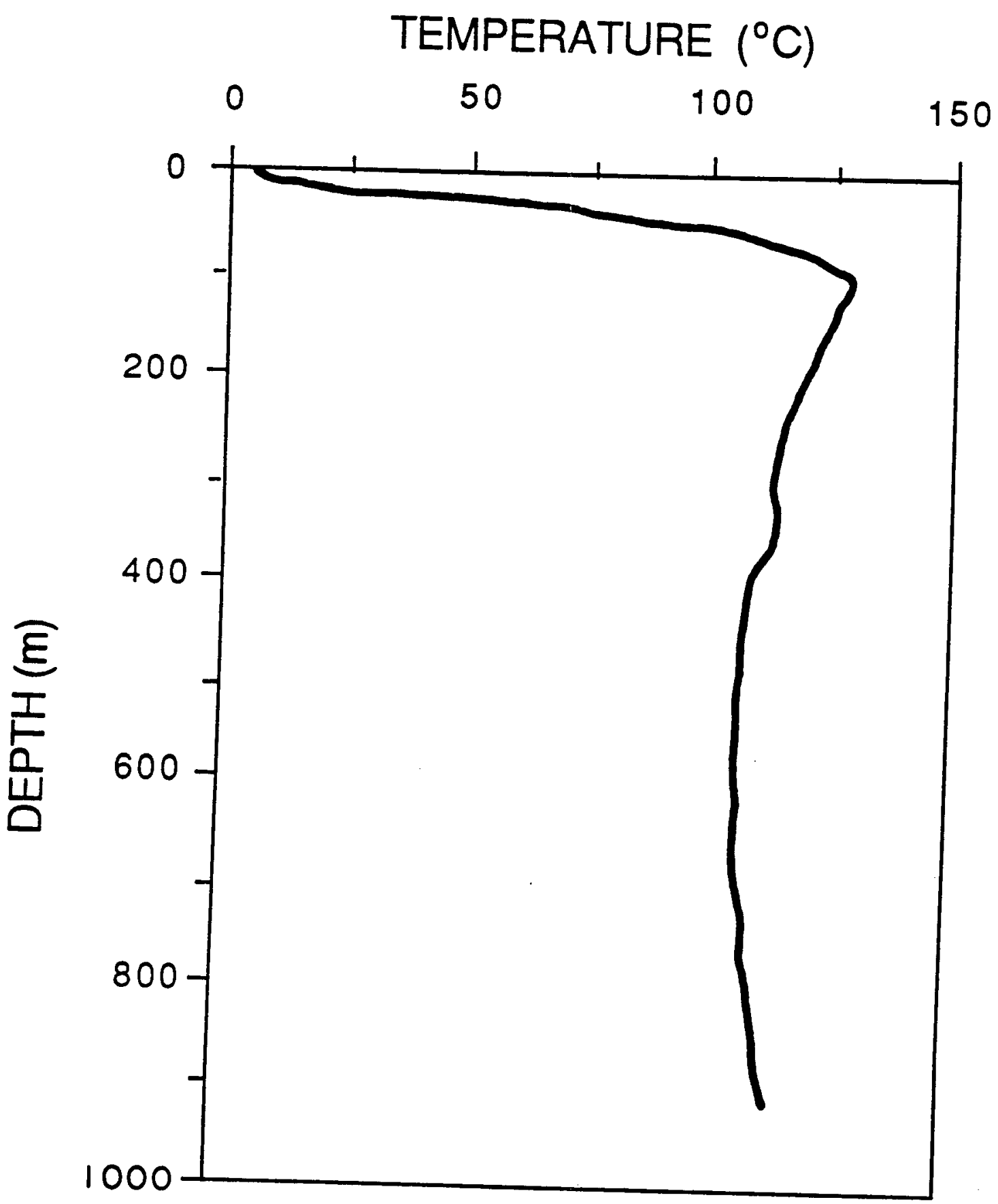

Figure 24. Temperature-Depth log for Union Geothermal - Christlansen \#1 Well (CHR-1). Detalled temperature profile is also shown on the well log composite (Plate 3). 
Union Geothermal Division (UNOCAL Corp.) generously provided unpublished results of thermal, geophysical, and lithology logging carried out in a deep exploration well (Christiansen \#1, designated in this study as CHR-1). These data are presented in Plate 3. The temperature-depth data are tabulated in Appendix $\mathrm{E}$ and plotted in both Appendix F and Figure 24. Temperatures exceeded $120^{\circ} \mathrm{C}\left(248^{\circ} \mathrm{F}\right)$ only between depths

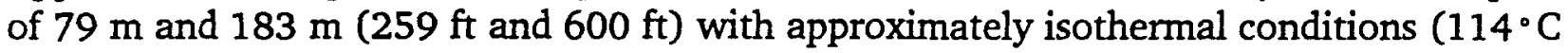
to $\left.119^{\circ} \mathrm{C}\right)$ found between $183 \mathrm{~m}$ and $912 \mathrm{~m}(600 \mathrm{ft}$ and $2992 \mathrm{ft})$. Because the temperature log contains a temperature reversal at shallow depth $(106 \mathrm{~m}$ or $348 \mathrm{ft})$, it seems reasonable to assume that the well penetrated a tongue of heated groundwater and missed the main upflow zone. If this is the case, temperatures greater than those observed in CHR-1, or boiling, might be expected at shallow depth in the center of the upflow zone.

Clement (1981) derived the heat flow map shown in Figure 25 using the temperature-depth data obtained from holes NC 2 through NC 12 and from 3 irrigation wells. Heat flow maxima exceed $3 \mathrm{~W} \mathrm{~m}^{-2}$ at NC-5 and NC-10. A minimum anomalous heat loss of $13 \mathrm{MW}$ is computed within the $9.4 \mathrm{~km}^{2}$ bounded by the $500 \mathrm{~mW} \mathrm{~m}$ contour $^{2}$ (Figure 25); assuming a background flux of $100 \mathrm{~mW} \mathrm{~m}^{-2}$ (Clement, 1981). The minimum volume discharge required to create the estimated heat loss is $0.032 \mathrm{~m}^{3} \mathrm{~s}^{-1}$. Rush (1983) independently estimated a similar volume discharge of $0.013 \mathrm{~m}^{3} \mathrm{~s}^{-1}$ and, using the results of chemical analyses of groundwater samples, proposed a reservoir temperature of $140^{\circ} \mathrm{C}$ to $170^{\circ} \mathrm{C}\left(284^{\circ} \mathrm{F}\right.$ to $\left.338^{\circ} \mathrm{F}\right)$.

Although the heat flow map shown in Figure 25 is poorly constrained to the north, northwest, and southeast, these and other data suggest the presence of a thermal plume of heated groundwater moving to the north from a source located at the mountain front (Chapman and others, 1981; Rush, 1983). A contour plot of groundwater temperature measured in water wells throughout the region (Figure 26, taken from Mower, 1982) outlines the approximate size of the thermal plume and reinforces the possibility that a blind geothermal system also exists near Beryl (Rush, 1983). A helium gas sniffer survey (Denton, 1976) reveals elevated values of helium concentration (Figure 27) located within the region of elevated heat flow indicated in Figure 25. Although maximum concentrations were obtained in a localized region in the immediate vicinity of NC-10, elevated values were also found near the mountain front. Rush (1983) suggests that the helium is released from solution in the groundwater as temperature and pressure decline in a region of lateral groundwater flow.

The data used to construct the heat flow map shown in Figure $\mathbf{2 5}$ are insufficient to accurately define either 1) the distribution and magnitude of maximum heat flow or 2) the size and location of the source of heated groundwater. Subsequent sections of this report describe a field-based study designed to obtain the information needed to clarify these issues and to help in refining the working model of the Newcastle geothermal system shown in Figure 21. 


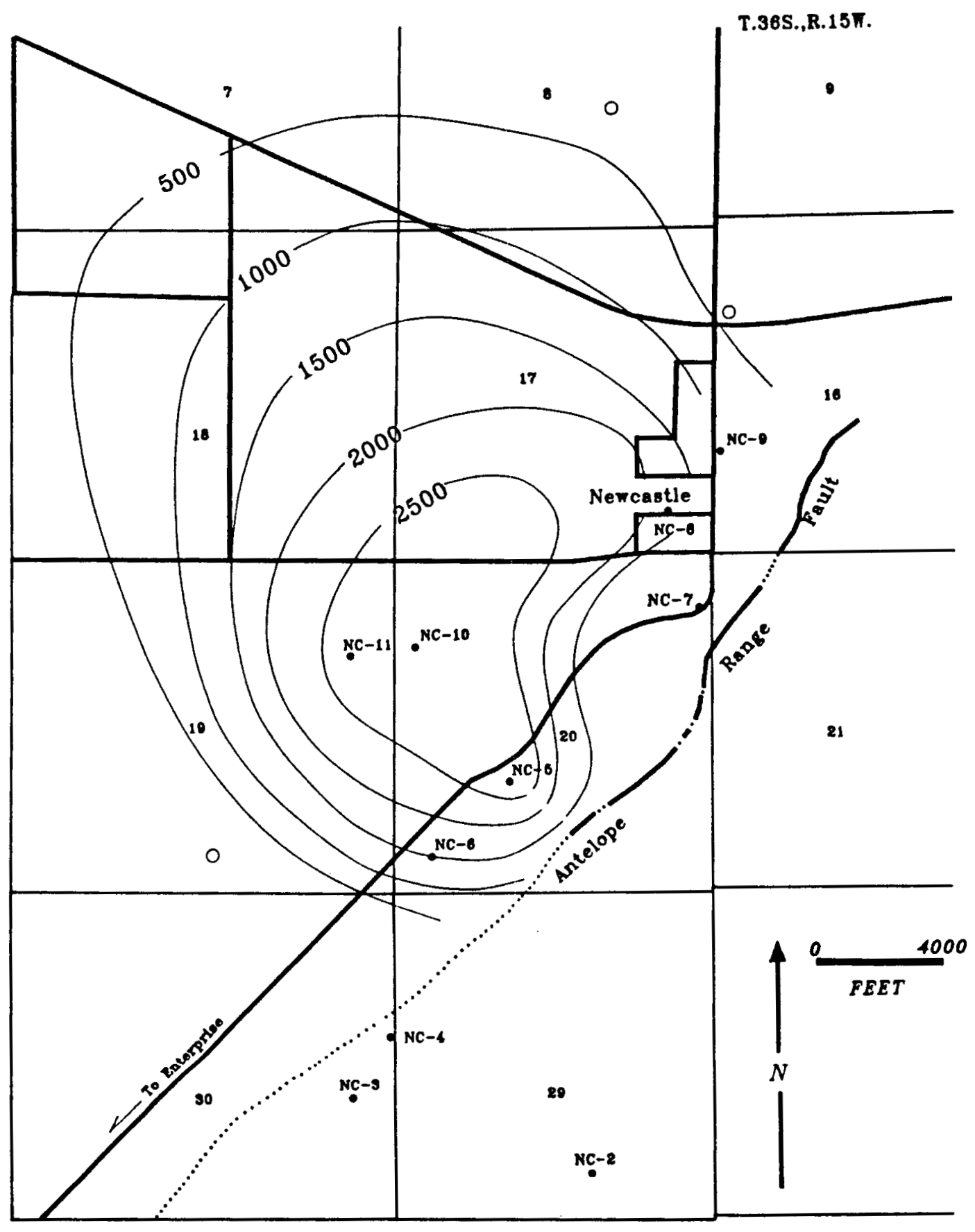

Figure 25. Heat flow map for the Newcastle geothermal system based on thermal data obtained from pre-existing NC wells and several irrigation wells. Heat flow contour values are given In $\mathrm{mW} \mathrm{m}^{-2}$. Solid circles indicate sites where heat flow is computed from actual temperature-depth and conductivity measurements. Open circles indicate sites where estimates were based on temperatures In Irrigation wells. From Clement (1981) and Chapman (and others, 1981). 


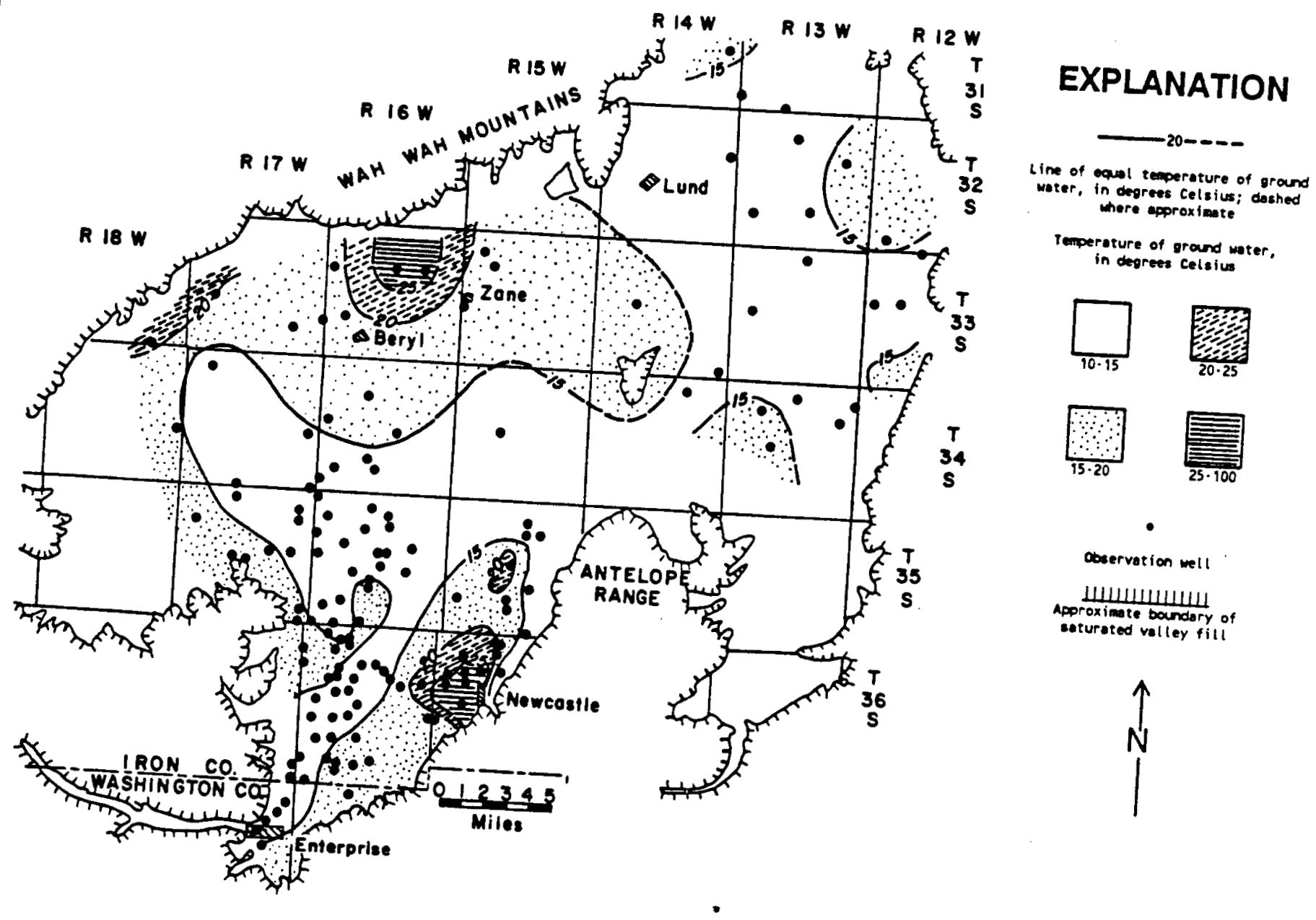

Figure 26. Contour map of the temperature of groundwater measured in wells of the
Beryl-Enterprise area. From Mower (1982) 


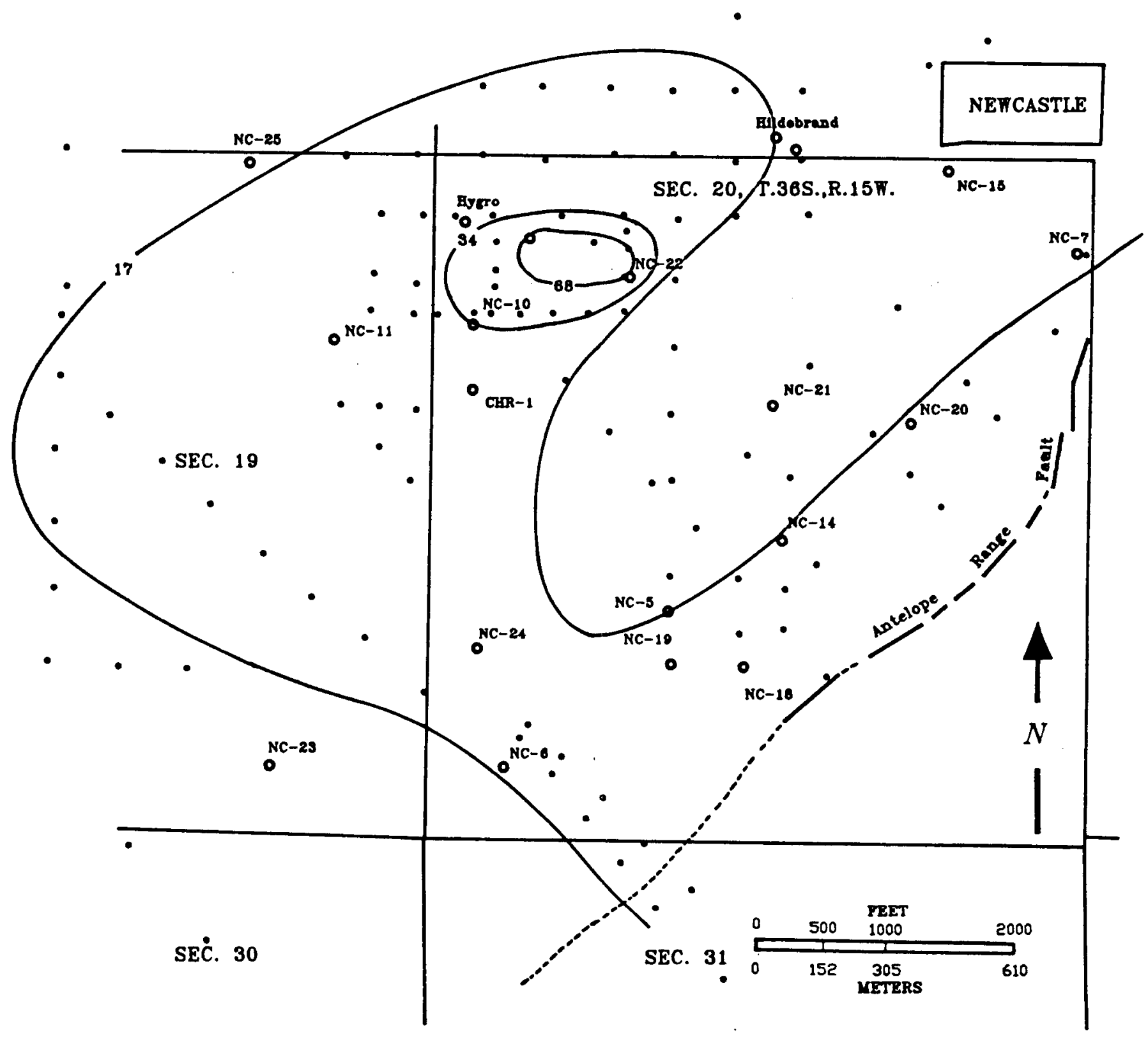

Figure 27. Contour map of helium concentrations in the Newcastle area at a depth of $0.6 \mathrm{~m}$ below the ground surface in the vicinity of Newcastle. From Denton (1976). Concentrations are parts per billion above atmosphere. 


\subsection{Subsurface Temperature Field and Heat Flow Data}

The principal objectives for the 1988-89 thermal measurement program were to delineate more precisely the margins and hence area of the geothermal system, the geometry of the outflow system, and in particular, the control exerted on the fluid discharge system by the range-front fault. To satisfy these objectives, twelve additional holes, designated NC-16 through NC-27, were drilled in September, 1988. Three additional existing water wells drilled by other parties, designated NC-13 through NC15, were also logged. The drill hole locations are shown on Figure 23.

The 12 new holes were drilled to a depth of $18 \mathrm{~m}(60 \mathrm{ft})$. Although deeper holes would have been desirable, on a fixed drilling budget there is a tradeoff between number of holes and depth of holes. On the basis of the existing temperature-depth data (Figure 22 ), it was argued that a depth of $120-150 \mathrm{~m}$ would be required to detect a temperature overturn. Shallower holes reveal principally a linear temperature profile, and there is little difference in information gained from holes $20,40,60$, or $80 \mathrm{~m}$ deep. Thus, a 20 $m$ depth was selected as being sufficiently deep to avoid the "noise" of annual surface temperature variations, and yet the minimum depth required to reveal the signature of the geothermal system. All holes were completed by inserting a bottom-capped 1.25" ID schedule 40 PVC pipe in the hole, filling the pipe with water, and back filling with drill cuttings.

\subsubsection{Temperature-depth results}

Temperatures were measured with thermistor transducers connected by four-wire cable to a digital ohmmeter. Fenwal K212E thermistors having a nominal $10 \mathrm{~K}$ ohm resistance at $20^{\circ} \mathrm{C}$, a power dissipation of $50 \mathrm{mWK}^{-1}$ in still water, and a response time of 7 seconds were used. The thermistors were calibrated against a Hewlett Packard digital quartz thermometer. Precision of the probes is $0.004 \mathrm{~K}$; accuracy of the temperature measurements considering calibration errors, field conditions, and ohmmeter resolution is considered to be $0.01 \mathrm{~K}$.

Temperature measurements are made most efficiently in drill holes filled with water because of the short equilibration time for the probe in water. Measurements made in air, above the water table in unsealed holes, require several minutes to arrive at thermal equilibrium. In the case of air-filled holes, a temperature-time series was obtained at each depth by measuring temperature every 20 seconds for a 5 -minute period, and equilibrium temperatures for those depths were determined using the extrapolation method of Parasnis (1971).

Temperature-depth data for the 15 new holes designated NC-13 through NC-27 are shown in Figure 28. Temperature-depth plots for two holes from the initial study 


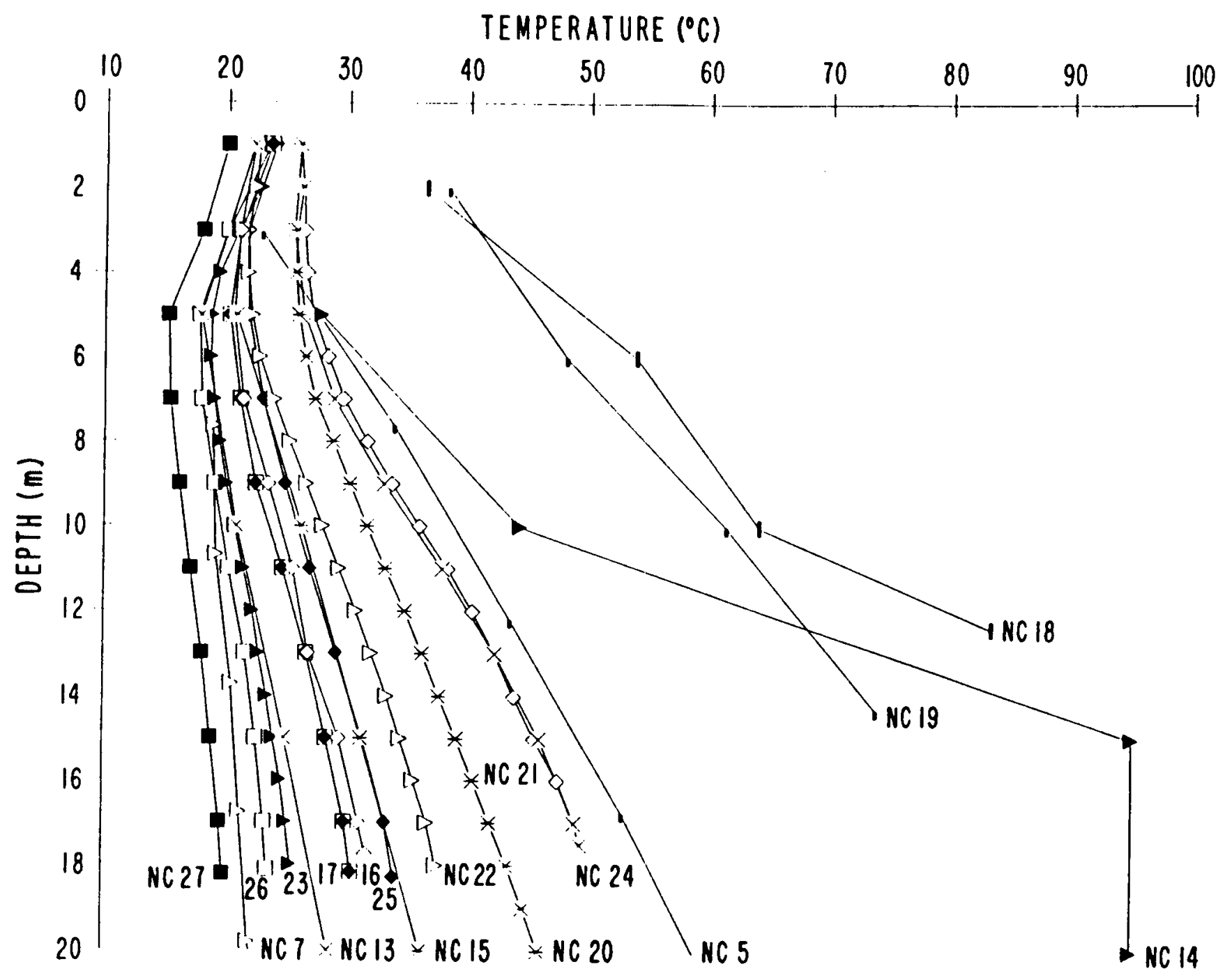

Figure 28. Composite plot of temperature-depth logs obtained from the thermal monitoring wells NC-14 through NC-27 installed in thls study. Individual logs and tabulated temperaturedepth data are contained In appendices E and F. Temperature-depth logs for NC-5 and NC. 7 are also shown to provide a reference to pre-existing thermal data. 
(NC-5 and NC-7) are included for comparison. Drill hole NC-5 has the highest thermal gradient previously determined, while the gradient in NC-7 is intermediate.

The first striking feature of the temperature field exhibited in the new drill holes is the extreme, near-surface geothermal gradient observed in the three holes drilled on the alluvial fan SSE of the developed geothermal system. Gradients in NC-14, NC-18 and NC-19 over the upper $15 \mathrm{~m}$ are about $5^{\circ} \mathrm{C} \mathrm{m}^{-1}$. Although holes NC-18 and NC-19 were drilled to a depth of $18 \mathrm{~m}$, the holes could only be logged to about $12 \mathrm{~m}$, presumably because the PVC casing lost strength and collapsed at temperatures above $70^{\circ} \mathrm{C}$. NC-14 was completed with a black iron pipe and exhibits $94^{\circ} \mathrm{C}$ at a depth of $15 \mathrm{~m}$, below which the hole is isothermal. This temperature field is somewhat enigmatic. None of these three holes intersected the water table. We considered the possibility that the deeper, open-hole NC-14 could be acting as a "chimney," providing for efficient vapor transport to the near surface ( $14 \mathrm{~m}$ depth) environment, or that boiling water convecting in the pipe could produce the isothermal condition. The similar thermal regime observed in NC18 and NC-19, shallow holes completed with air-filled plastic pipe, argues against the thermal field seen in NC-14 being simply a borehole effect, rather, that it is a property of the SSE extremity of the geothermal system. We speculate that the isothermal temperature field at $94^{\circ} \mathrm{C}$ may result from vapor circulating within the alluvial fan at or near the boiling point of water at this elevation, with the upper $15 \mathrm{~m}$ being a conductive boundary on the vapor system. This speculation should be checked with further field measurements and model studies.

A second noteworthy aspect of Figure 28 is the regular behavior of temperaturedepth profiles in general. The curved profiles in the uppermost $6 \mathrm{~m}$ are an expected transient effect of an annual temperature variation at the ground surface and is not of importance in understanding the geothermal system. Between depths of 6 and $20 \mathrm{~m}$, however, most of the profiles are linear, indicating that heat transfer through this region is predominantly conductive. The wide range in gradients observed in these very shallow holes carry a strong signal of the Newcastle geothermal system and vindicate the use of $20 \mathrm{~m}$ holes for geothermal exploration in this circumstance.

\subsubsection{Heat flow map for the Newcastle geothermal system}

Heat flow was calculated for each well by combining the thermal gradient information with thermal conductivity measured on drill cuttings or interpolated from nearby wells. Because laboratory measurements yield the solid rock matrix thermal conductivity, a porosity of $30 \%$ was assumed to compute the bulk conductivity of the alluvial fan material in situ. Basic information on thermal gradient, depth interval over which the gradient was calculated, thermal conductivity measurement, and heat flow is given in Table 2. A new heat flow map for the Newcastle geothermal system is shown in Figure 29. 


\begin{tabular}{|c|c|c|c|c|c|c|c|}
\hline $\begin{array}{c}\text { NC } \\
\text { Well }\end{array}$ & $\begin{array}{c}\text { Depth } \\
\text { Interval } \\
(\mathrm{m})\end{array}$ & $\begin{array}{c}\text { Thermal } \\
\text { Gradient } \\
(\mathrm{K} / \mathrm{km})\end{array}$ & $\begin{array}{c}\mathrm{N} \\
\text { (\# thermal } \\
\text { conductivity } \\
\text { measurements) }\end{array}$ & $\begin{array}{c}\text { (a) } \\
\text { Thermal } \\
\text { Cond. } \\
(\mathrm{W} / \mathrm{m} \mathrm{K})\end{array}$ & $\begin{array}{c}\text { (b) } \\
\text { Heat } \\
\text { Flow } \\
(\mathrm{mW} / \mathrm{m} \mathrm{m})\end{array}$ & $\begin{array}{l}\text { (c) } \\
\text { Thermal } \\
\text { Cond. } \\
\text { (W/m K) }\end{array}$ & $\begin{array}{c}\text { (d) } \\
\text { Heat } \\
\text { Flow } \\
(\mathrm{mW} / \mathrm{m} \mathrm{m})\end{array}$ \\
\hline 2 & 46 to 89 & 89 & 0 & 2.27 & 200 & 2.27 & 200 \\
\hline 3 & 46 to 89 & 116 & 0 & 1.7 & 200 & 1.7 & 200 \\
\hline 4 & 8 to 40 & 220 & 0 & 1.7 & 370 & 1.7 & 370 \\
\hline 5 & 8 to 20 & 1,998 & 0 & 1.7 & 3,400 & 1.7 & 3,400 \\
\hline 6 & 5 to 38 & 1,065 & 0 & 1.7 & 1,810 & 1.73 & 1,840 \\
\hline 7 & 8 to 47 & 370 & 0 & 1.7 & 630 & 1.7 & 630 \\
\hline 8 & 17 to 41 & 1,028 & 0 & 1.7 & 1,750 & 1.7 & 1,750 \\
\hline 9 & 8 to 56 & 710 & 0 & 1.7 & 1,210 & 1.7 & 1,210 \\
\hline 10 & 0 to 40 & 1,833 & 0 & 1.7 & 3,120 & 1.76 & 3,230 \\
\hline 11 & 15 to 46 & 1,292 & 0 & 1.7 & 2,200 & 1.74 & 2,250 \\
\hline 12 & 49 to 118 & 21 & 0 & 1.7 & 40 & 1.7 & 40 \\
\hline 13 & 5 to 20 & 729 & 0 & 1.7 & 1,240 & 1.7 & 1,240 \\
\hline 14 & 0 to 14 & $>5,000$ & 0 & 1.7 & $>8,500$ & 1.72 & $>8,600$ \\
\hline 15 & 5 to 40 & 1,010 & 0 & 1.7 & 1,720 & 1.68 & 1,700 \\
\hline 16 & 5 to 18 & 931 & 6 & 1.7 & 1,580 & 1.8 & 1,680 \\
\hline 17 & 5 to 18 & 847 & 6 & 1.7 & 1,440 & 1.67 & 1,410 \\
\hline 18 & 0 to 13 & 5,737 & 7 & 1.7 & 9,750 & 1.83 & 10,500 \\
\hline 19 & 0 to 14 & 4,615 & 7 & 1.7 & 7,850 & 1.83 & 8,450 \\
\hline 20 & 5 to 20 & 1,409 & 7 & 1.7 & 2,400 & 1.7 & 2,400 \\
\hline 21 & 5 to 17.5 & 1,943 & 6 & 1.7 & 3,300 & 1.64 & 3,190 \\
\hline 22 & 5 to 18 & 1,267 & 6 & 1.7 & 2,150 & 1.57 & 1,990 \\
\hline 23 & 5 to 18 & 582 & 6 & 1.7 & 990 & 1.8 & 1,050 \\
\hline 24 & 5 to 17 & 1,914 & 5 & 1.7 & 3,250 & 1.55 & 2,970 \\
\hline 25 & 5 to 18 & 982 & 6 & 1.7 & 1,670 & 1.72 & 1,690 \\
\hline 26 & 7 to 18 & 521 & 4 & 1.7 & 890 & 1.54 & 800 \\
\hline 27 & 5 to 18 & 412 & 6 & 1.7 & 700 & 1.6 & 660 \\
\hline
\end{tabular}

Notes

(a) Thermal conductivity for all wells in alluvium have been assigned a value of 1.7 $\mathrm{W} / \mathrm{m} \mathrm{K}$ based on a mean matrix conductivity of $2.64 \mathrm{~W} / \mathrm{m} \mathrm{K}$ and assumed porosity of $30 \%$; conductivity for NC 2 in volcanic tuff assumes a $10 \%$ porosity.

(b) Heat flow computed using thermal gradients given in column 3 and conductivities from column (a).

(c) Actual thermal conductivity measurements used for NC 16-NC 27; conductivity for other wells estimated by interpolation from measured wells.

(d) Heat flow computed using thermal gradients given in column 3 and conductivities from column (c).

Table 2. Summary of temperature gradlent, thermal conductivlty, and heat flow data for thermal monttoring wells NC-2 through NC-27. 


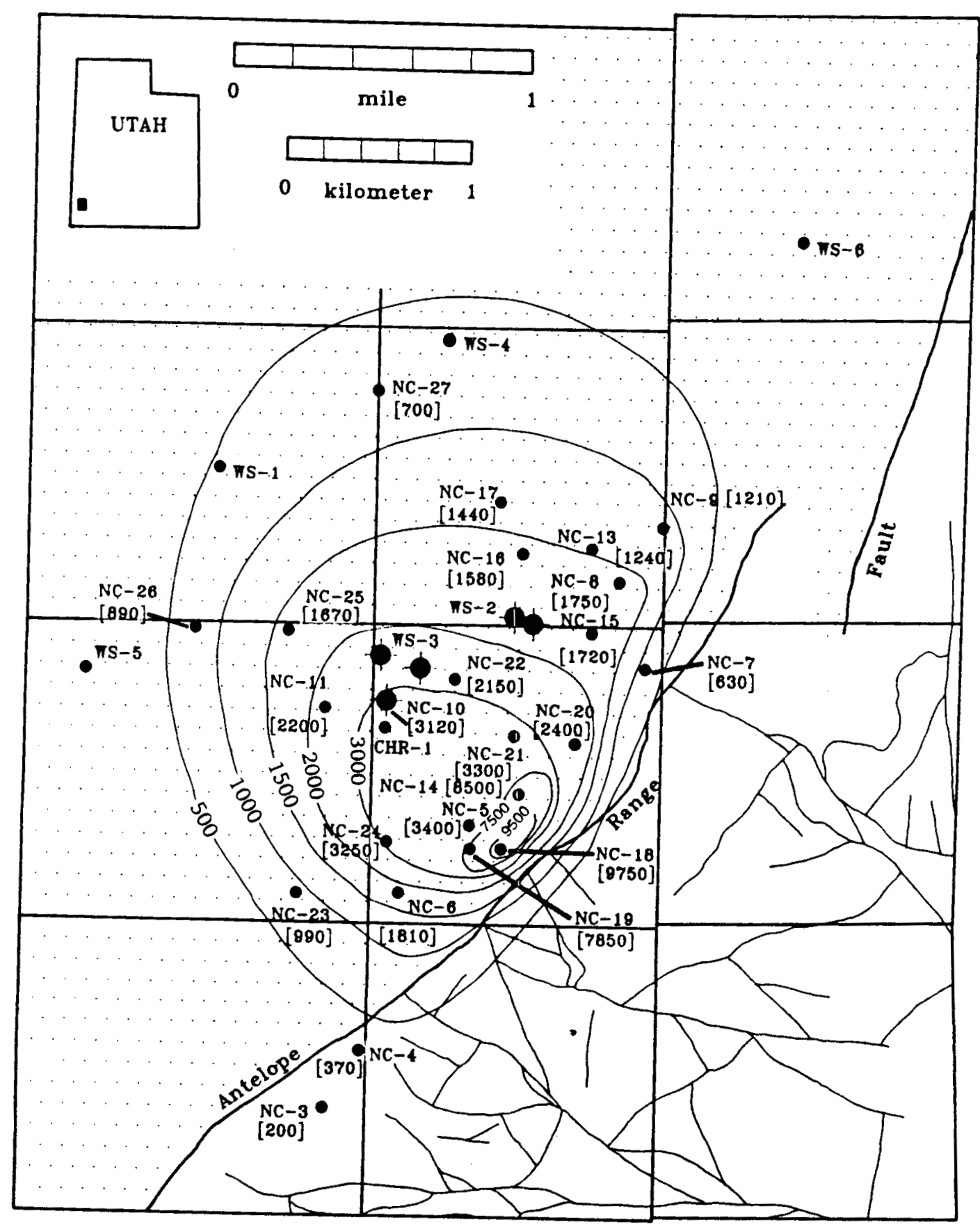

Figure 29. Revlsed heat flow map for the Newcastle geothermal system updated using data obtained In this study. Heat flow values and contour values are given in $\mathrm{mW} \mathrm{m}^{-2}$. Compare this map to the previous heat flow map shown in Figure 25. 
The lowest thermal gradients in Figure 28, and lowest heat flow values in Table 2 (with the exception of holes clearly away from the geothermal area), are observed in $\mathrm{NC}-27$ and NC-26 at the northern and northwestern boundaries of the thermal anomaly (see Figure 29). These results are significant because they now provide firm constraints on the lateral extent of the system, previously based on low-quality irrigation well data and speculation. Likewise, the thermal gradients and heat flow for NC-20 and NC-23 limit the northeast and southwest extent of the geothermal system along strike of the Antelope Range fault respectively. Wells NC-13, NC-15, NC-16 and NC-17, all situated near the western edge of the town of Newcastle, clearly show that the town is located over a distal part of the outflow region, and that geothermal development in the town itself is limited.

New extreme heat flow results from NC-14, NC-18 and NC-19, on the other hand, indicate that the hottest part of the geothermal system extends further to the southeast than is suggested in the previous heat flow map (Figure 13 of Chapman et. al, 1981, and Figure 25 of this report). The new heat flow map (Figure 29) suggests a much more direct role for the range bounding Antelope Range fault in controlling leakage of hot fluids up to the water table.

We have made a new heat loss estimate for the Newcastle geothermal system by integrating the anomalous flux over the heat flow map shown in Figure 29. Details of the integration are given in Table 3. Anomalous heat loss above the background heat flow of $100 \mathrm{~mW} \mathrm{~m}^{-2}$, and contained within the $500 \mathrm{~mW} \mathrm{~m}^{-2}$ contour, is $12.4 \mathrm{MW}$. This value is slightly less than the 12.8 MW computed previously by Chapman et. al (1981) because the increased heat flow over a small area on the alluvial fan is offset by a shrinking of several contour areas in the better constrained new map. The revised fluid discharge, based on our new estimates of heat loss, but otherwise using the same parameters proposed by Chapman et. al (1981) is $0.031 \mathrm{~m}^{3} \mathrm{~s}^{-1}$.

\begin{tabular}{|c|c|c|c|}
\hline $\begin{array}{c}\text { Heat flow } \\
\text { contour interval } \\
\left(\mathrm{W} \mathrm{m} \mathrm{m}^{-2}\right) \\
\end{array}$ & $\begin{array}{c}\text { Area } \\
\left(10^{6} \mathrm{~m}^{2}\right)\end{array}$ & $\begin{array}{c}\text { Average } \\
\text { heat flow } \\
\left(\mathrm{W} \mathrm{m} \mathrm{m}^{-2}\right)\end{array}$ & $\begin{array}{l}\text { Heat loss } \\
\text { (MW) }\end{array}$ \\
\hline $\begin{array}{l}0.5 \text { to } 1.0 \\
1.0 \text { to } 1.5 \\
1.5 \text { to } 2.0 \\
2.0 \text { to } 3.0 \\
3.0 \text { to } 6.0 \\
6.0 \text { to } 9.0 \\
>9.0\end{array}$ & $\begin{array}{l}3.1 \\
1.8 \\
1.5 \\
0.83 \\
0.64 \\
0.10 \\
0.033 \\
\end{array}$ & $\begin{array}{l}0.75 \\
1.25 \\
1.75 \\
2.50 \\
4.50 \\
7.50 \\
2.00\end{array}$ & $\begin{array}{l}2.3 \\
2.2 \\
2.6 \\
2.1 \\
2.9 \\
0.8 \\
0.3\end{array}$ \\
\hline Total & 8.0 & & 13.2 \\
\hline Background heat loss & 8.0 & 0.10 & 0.8 \\
\hline Heat loss above background & & & 12.4 \\
\hline
\end{tabular}

Table 3. Heat loss for the Newcastle geothermal system. 


\subsection{Hydrochemistry and Stable Isotopes}

Mower (1982) presents a contour map of the electrical conductance of groundwater found in water wells in the Beryl-Enterprise area (Figure 30). Because electrical conductance is directly influenced by the total dissolved solids content (TDS) of the groundwater (Freeze and Cherry, 1979), the map shown in Figure 30 indicates several regions of groundwater containing elevated concentrations of TDS. We interpret the rough correspondence between regions of elevated groundwater conductance, shown in Figure 30, and regions of elevated groundwater temperature shown in Figure 26 as evidence for movement of that heated, more evolved groundwater, from a deeper flow system to the shallow freshwater system that predominates in the valley-fill alluvium.

CONCENTRATION (ppm)

\begin{tabular}{|c|c|c|c|c|c|c|}
\hline SPECIES & WS. 1 & WS-2 & WS-3 & WS.4 & WS $-5 *$ & WS -6 * \\
\hline $\begin{array}{l}\mathrm{Na} \\
\mathrm{K} \\
\mathrm{Ca} \\
\mathrm{Mg}\end{array}$ & $\begin{array}{c}24.58 \\
2.76 \\
54.05 \\
25.57\end{array}$ & $\begin{array}{l}273.28 \\
15.24 \\
64.57 \\
0.75\end{array}$ & $\begin{array}{c}290.24 \\
16.97 \\
78.68 \\
0.69\end{array}$ & $\begin{array}{l}249.61 \\
11.74 \\
64.36 \\
5.51\end{array}$ & $\begin{array}{c}63.98 \\
2.64 \\
63.82 \\
25.59\end{array}$ & $\begin{array}{l}104.80 \\
5.05 \\
62.34 \\
13.32\end{array}$ \\
\hline $\begin{array}{c}\mathrm{Fe} \\
\mathrm{Al} \\
\mathrm{SiO}_{2} \\
\mathrm{~B} \\
\mathrm{Li} \\
\mathrm{Sr}\end{array}$ & $\begin{array}{c}\text { N.D. } \\
\text { N.D. } \\
42.12 \\
\text { N.D. } \\
0.50 \\
\text { N.D. }\end{array}$ & $\begin{array}{c}\text { N.D. } \\
\text { N.D. } \\
79.19 \\
0.34 \\
0.52 \\
1.3\end{array}$ & $\begin{array}{l}\text { N.D. } \\
\text { N.D. } \\
69.37 \\
\text { N.D. } \\
0.60 \\
1.56\end{array}$ & $\begin{array}{c}\text { N.D. } \\
\text { N.D. } \\
63.24 \\
0.62 \\
0.33 \\
0.36\end{array}$ & $\begin{array}{c}\text { N.D. } \\
\text { N.D. } \\
31.89 \\
0.15 \\
\text { N.D. } \\
0.55\end{array}$ & $\begin{array}{c}\text { N.D. } \\
\text { N.D. } \\
46.80 \\
0.19 \\
0.09 \\
0.35\end{array}$ \\
\hline $\begin{array}{c}\mathrm{HCO}_{3} \\
\mathrm{CO}_{3} \\
\mathrm{Cl} \\
\mathrm{F} \\
\mathrm{SO}_{4}\end{array}$ & $\begin{array}{c}181.0 \\
\text { N.D. } \\
48.00 \\
0.30 \\
82.00\end{array}$ & $\begin{array}{c}58.00 \\
\text { N.D. } \\
69.00 \\
7.30 \\
569.00\end{array}$ & $\begin{array}{c}44.00 \\
\text { N.D. } \\
104.00 \\
6.30 \\
637.00\end{array}$ & $\begin{array}{c}104.00 \\
\text { N.D. } \\
76.00 \\
4.70 \\
478.00\end{array}$ & $\begin{array}{c}182.00 \\
\text { N.D. } \\
44.00 \\
0.48 \\
208.00\end{array}$ & $\begin{array}{c}228.00 \\
\text { N.D. } \\
82.00 \\
1.03 \\
115.00\end{array}$ \\
\hline $\begin{array}{l}\text { Total. Diss. Solids. } \\
\text { measured }[\mathrm{m}] \\
\text { calculated[c] } \\
100 \times(\mathrm{m} / \mathrm{c})\end{array}$ & $\begin{array}{c}364.00 \\
368.88 \\
98.68\end{array}$ & $\begin{array}{l}1154.00 \\
1109.01 \\
104.06\end{array}$ & $\begin{array}{c}1236.00 \\
1227.03 \\
100.73\end{array}$ & $\begin{array}{c}1016.00 \\
1005.60 \\
101.03\end{array}$ & $\begin{array}{l}530.00 \\
530.59 \\
99.89\end{array}$ & $\begin{array}{l}545.00 \\
543.00 \\
100.35\end{array}$ \\
\hline $\mathrm{pH}$ & 7.74 & 8.03 & 7.98 & 7.89 & 7.48 & 7.60 \\
\hline
\end{tabular}

NOTE: * Because contamination of acidified splits was suspected, non-acidified splits were analyzed.

Table 4. Results of chemical analyses of groundwater samples from the Newcastle area. 


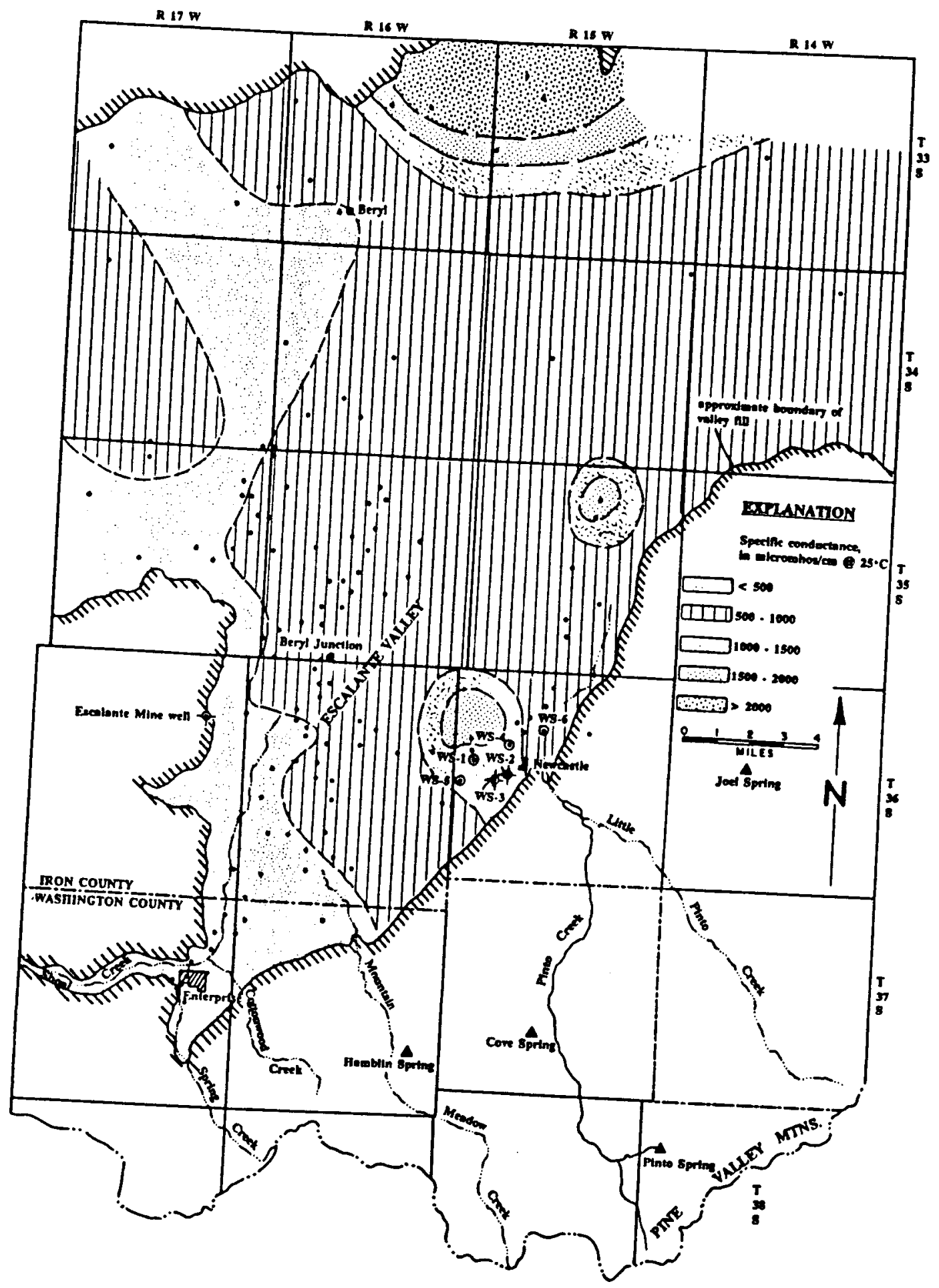
Figure 30. Specific conductance of groundwater measured in wells in the vicinity of Newcastle,
Utah. The locations of groundwater samples collected in this study for water chemistry and
stable Isotope analyses are also indlcated. From Mower (1982). 
Page missing from original document 


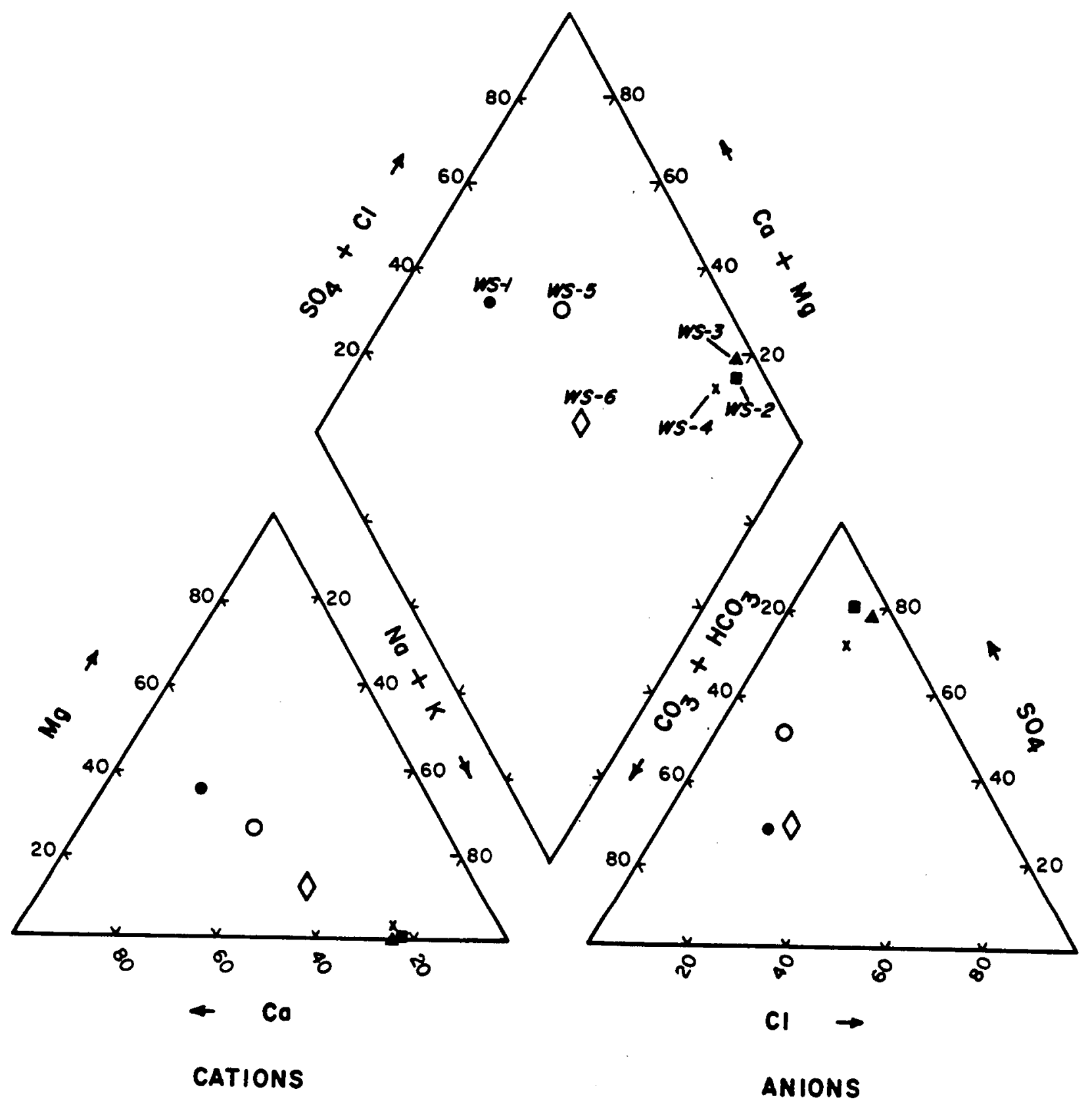

Figure 31. Tri-linear PIper dlagram of water chemistry analyses obtained for groundwater samples
WS-1 through WS-6. Scales shown WS-1 through WS-6. Scales shown are in total milliequivalent per liter. 
re-equilibrium takes place after the fluid leaves the reservoir, and 5) reservoir fluid does not mix with other meteoric water.

Several inferences can be made given the results shown in Table 5 . First, computed temperatures are low. Only the NC-10 sample collected by Rush (1983) yields estimated temperatures in excess of $120^{\circ} \mathrm{C}\left(248^{\circ} \mathrm{F}\right)$. Although the temperature of $166^{\circ} \mathrm{C}$ $\left(331^{\circ} \mathrm{F}\right)$ calculated for the NC-10 sample using the Na-K-Ca geothermometer is within the temperature range computed by Rush $\left(140^{\circ} \mathrm{C}\right.$ to $\left.170^{\circ} \mathrm{C}\right)$, this result may be an artifact of choosing an inappropriate scaling factor in the calculation (M. Adams, pers. comm., 1989). Results computed for WS-1, 5, and 6 indicate temperatures that fall below the range where geothermometry calculations are applicable. Second, the maximum computed temperatures $\left(100^{\circ} \mathrm{C}\right.$ to $\left.120^{\circ} \mathrm{C}\right)$ approach the maximum temperature of $130^{\circ} \mathrm{C}$ measured at a depth of $106 \mathrm{~m}$ in CHR-1. This suggests that the fluid chemistry may reflect conditions more representative of the shallow outflow portion of the hydrothermal system, rather than those of a deep geothermal reservoir. Third, from a qualitative perspective, samples WS-3, 2, 4 and 1 indicate a progression of increasingly mixed fluid with the sample from WS-3 and 2 being about $90 \%$ of original, WS- 4 about $40 \%$, and WS-1 about 5\% (Adams, pers. comm., 1989). The distinctive chemical character of sample WS-1 suggests that this sample may be a dilute version of the groundwater discharging to the valley-fill deposits, or the sample may be typical of groundwater chemistry found throughout the valley-fill deposits. In either case, computed temperatures shown in Table 5 for this sample, and for samples WS-5 and 6, do not provide a reliable indication of groundwater temperatures at greater depths in the hydrothermal system.

TEMPERATURE $\left.{ }^{\circ} \mathrm{C}\right)$

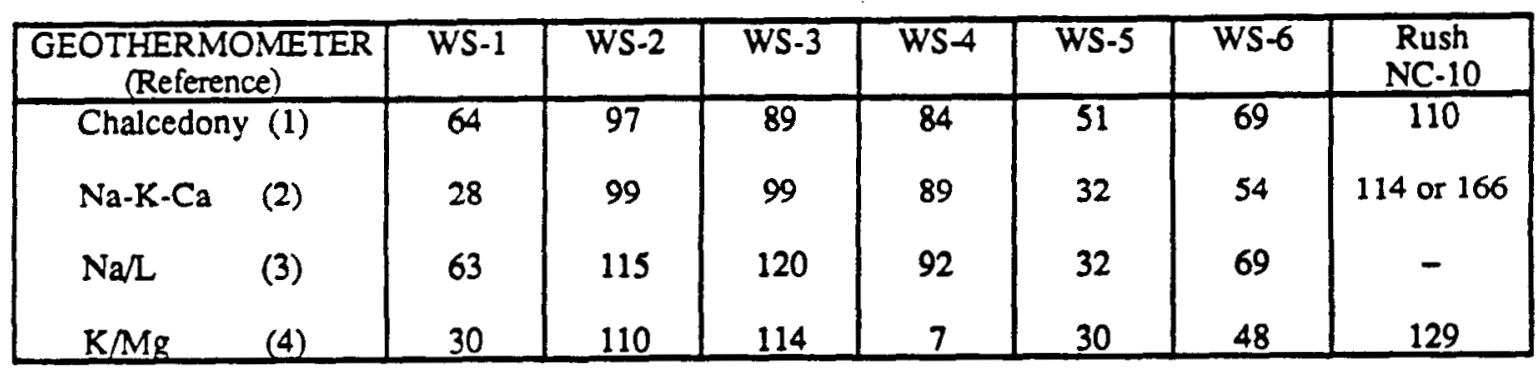

(1) Foumier (1981)

(3) Fouillac and Michard (1981)

(2) Fournier and Truesdell (1973)

(4) Giggenbach (1988)

Table 5. Results of geothermometry calculations carrled out using chemical analyses of groundwater samples obtained near Newcastle, Utah. 


\subsubsection{Light Stable Isotope Analyses}

Stable isotope data obtained from groundwater samples collected at several wells and springs in the vicinity of Newcastle (Figure 30) are tabulated in Table 6 and plotted in Figure 32. Isotope analyses were carried out by Dr. J. Bowman of the University of Utah. Uncertainty in the analytical results is approximately \pm 1 in $\delta D$ and \pm 0.15 in $\delta^{18} \mathrm{O}$. Where two values are reported for $\delta \mathrm{D}$ or $\delta^{18} \mathrm{O}$, each determination was made on different aliquots of the water sample. The average of these data pairs was used in plotting the results shown in Figure 32.

\begin{tabular}{|l|c|c|}
\hline SAMPLE LOCATION & $\delta 180$ & $\delta \mathrm{D}$ \\
\hline Cove Spring & -13.0 & -95 \\
Pinto Spring & $-13.9,-14.0$ & $-104,-103$ \\
Hildbrand Well (WS-2) & -14.2 & -107 \\
Troy Hygro Well (WS-3) & $-14.0,-14.3$ & -108 \\
Joel Spring & -14.0 & -103 \\
Escalante Mine & -13.0 & -94 \\
Hamblin Spring & $-12.6,-12.4$ & $-91,-92$ \\
\hline
\end{tabular}

Table 6. Results of light stable lsotope analyses $\left(\delta 0\right.$ and $\delta^{18} \mathrm{O}$ expressed as per mil relative to VSMOW) carrled out on groundwater samples obtained from springs and wells near Newcastle, Utah.

Stable isotope data obtained from springs and wells in the Newcastle area spans a relatively narrow range of values in both $\delta \mathrm{D}$ and $\delta^{18} \mathrm{O}$ (Figure 32). The fact that the results of all analyses lie close to the Meteoric Water Line defined by Dansgaard (1964) suggests that each water sample originated as meteoric water with little isotope fractionation or exchange during flow through the subsurface. The meteoric signature of samples WS-3 and 4, obtained within the thermal-çhemical plume identified previously, suggest that the heated groundwater is derived from meteoric water recharged in the adjacent highlands, rather than generated by the loss of volatiles from an underlying igneous intrusion.

The commonly noted correlation between decreasing $\delta \mathrm{D}$ and increasing elevation of groundwater recharge suggests that groundwater in the thermal-chemical plume was recharged at higher elevations than groundwater sampled at the springs. Review of topographic maps in the Newcastle area indicates that the springs may represent discharge from relatively shallow groundwater flow systems with recharge at higher elevations on the same slope. Relatively deep circulation in a regional-scale flow system 
with a recharge area that extends to the Pine Valley Mountains $20 \mathrm{~km}$ (12 mi) southeast of Newcastle may contribute to the relatively low $\delta \mathrm{D}$ values found in the well samples.

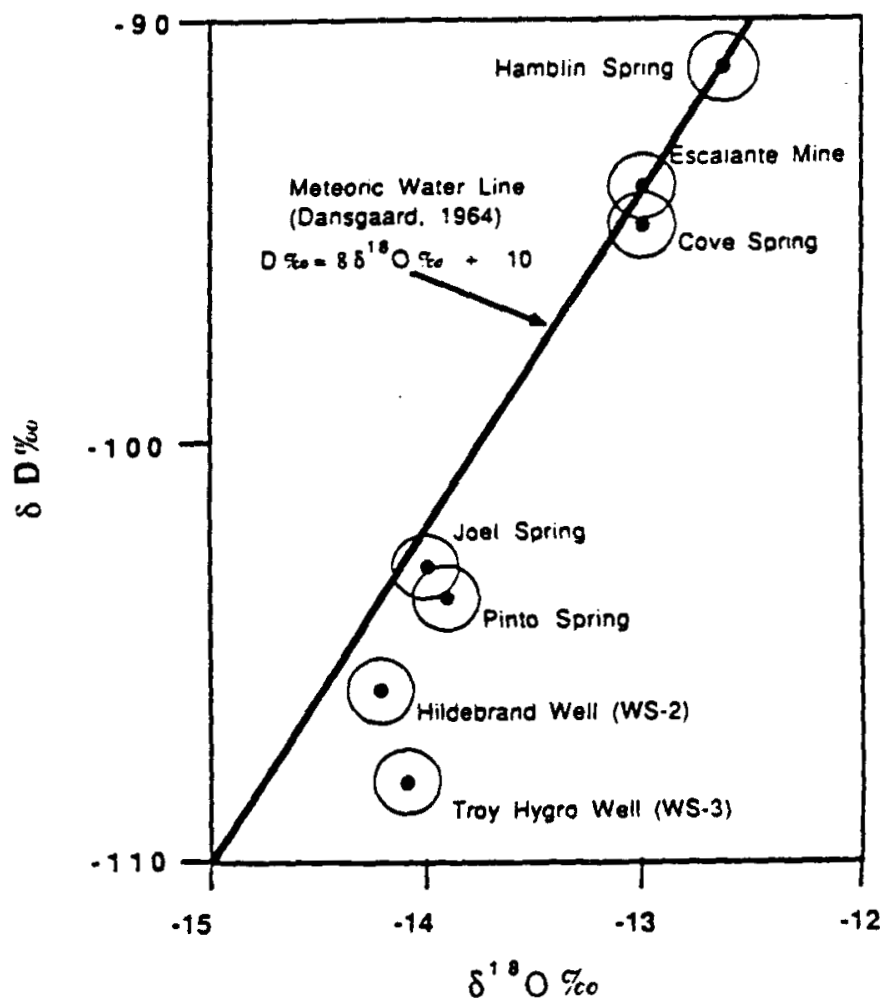

Figure 32. Plot of $\delta \mathrm{D}$ against $\delta 180$ showing the results of stable isotope analyses for groundwater samples obtained from springs and wells located near Newcastle, Utah. Sample locations are indicated in Figure 30.

\subsection{Hydrologic Interpretation of Geophysical Studies}

Land-based gravity surveys performed as part of this study, and described in a previous section, provide insight into the character and thickness of the valley-fill deposits shown in the working model of Figure 21 . In addition to indicating the possible depth to bedrock beneath the valley floor (about $1.6 \mathrm{~km}$ or $1 \mathrm{mi}$ ), the gravity results also suggest that a wedge-shaped region with density slightly elevated above that of the adjacent valley-fill deposits (2125 $\mathrm{kg} \mathrm{m}_{3}$ as compared to $1900 \mathrm{~kg} \mathrm{~m}^{3}$ ) may abut the bedrock-alluvium contact (Figure 13). This apparent increase in density could reflect a reduction in porosity caused by mineral precipitation within the unconsolidated deposits or sediment compaction. Geophysical logs obtained from the Union Geothermal Christiansen \#1 Well (Plate 3) indicate a uniform density of about $2300 \mathrm{~kg} \mathrm{~m}^{-3}$ between $300 \mathrm{~m}(984 \mathrm{ft})$ and the total depth of $912 \mathrm{~m}(2992 \mathrm{ft})$. This value is intermediate 
between those indicated in the gravity model $\left(2125 \mathrm{~kg} \mathrm{~m}^{-3}\right.$ in the unconsolidated wedge and $2400 \mathrm{~kg} \mathrm{~m}^{-3}$ in the underlying bedrock).

The results of regional-scale gravity surveys compiled by $\mathrm{Pe}$ (1980) are shown in Figure 8. Given the relatively flat topography of the valley floor, it is clear that the Newcastle system is situated near the center of a significant gravity low that marks the intersection of two lines of gravity lows .- a dominant trend oriented northeast and another, discontinuous trend oriented northwest. It seems reasonable to assume that the gravity lows coincide with unconsolidated to moderately consolidated deposits filling isolated basins caused by regional-scale normal faulting. The northeast-southwest line of gravity lows coincides with the Antelope Range fault and its extension that marks the southeast boundary of the Escalante Valley. Field mapping has not identified a regionalscale fault zone that coincides with the northwest-southeast trending line of gravity lows, although structural analysis within the adjacent range has revealed a complex network of bedrock faults, about $3 \mathrm{~km}$ wide, that lies along this trend. It is possible that the northwest trend of gravity lows represent basin fill deposits generated during regional southwest-directed (detachment style?) extension that were dismembered by later basinrange extension that produced the dominant northeast-trending set of lows. Increased fracture density may provide for locally enhanced bedrock permeability in the vicinity of the gravity lows. Alignment of these presumed regions of enhanced permeability in northwest-southeast and northeast-southwest directions likely provides preferred pathways for groundwater flow in bedrock that place important constraints on the character of the Newcastle geothermal system.

Electrical resistivity surveys carried out as part of this study, and summarized in a previous section, indicate a pattern of reduced resistivity that suggests a plume-like discharge of groundwater with elevated TDS from a subsurface source to the adjacent valley-fill deposits (Figure 15). Review of the apparent resistivity data suggests that the plume emanates from a $1.5 \mathrm{~km}(0.9 \mathrm{mi})$ (minimum) region aligned with the mountain front. The presence of a bulls-eye like SP anomaly (see section 3.2.2) appears to indicate a primary zone of localized upflow near wells NC-18 and NC-19.

\subsection{Numerical Modeling}

The numerical modeling component of this study was originally intended to provide insight into the rates and patterns of fluid flow that might contribute to the thermal observations described in previous sections. It was anticipated that a series of steady state simulations of coupled fluid flow and heat transfer in systems with 2-dimensional symmetry could be used to explore the nature of the hydrothermal system. It became apparent during the modeling studies; however, that the Newcastle system has a strong 3-dimensional character that precludes using 2-dimensional models to gain anything more than rudimentary clues regarding the details of the hydrothermal system. Although inconclusive, the modeling effort provides the important result that the thermal regime 
likely has a complex 3-dimensional character that can only be represented with a full 3-D modeling approach.

\subsubsection{Modelling Approach}

Figure 33 shows the generalized boundary value problems solved in exploring the characteristics of the working model for the Newcastle hydrothermal system shown in Figure 21. The full-length problem has planar symmetry (Figure 33a) while both planar and radial symmetry were modeled with the smaller problem (Figure 33b). In each case, vertical boundaries are insulated and have specified fluid flux. The horizontal basal boundary is assumed impervious to fluid flow. Regional conductive heat flow is represented by a uniform heat flux applied across the basal boundary. The upper boundary of the domain is the ground surface. The thin cover of discontinuous surficial deposits typical of upland areas of mountain slopes is viewed as a thin skin of variable thickness that is not explicitly included in the model. Resistance to heat transfer in the thin surficial deposits (soils, colluvium, etc.) is assumed negligible so temperatures at the bedrock surface in the mountain range match those at the ground surface. Surface temperature conditions are defined in terms of a reference surface temperature and a thermal lapse rate.

A free-surface method is used to solve for the position of the water table within the constraints of groundwater recharge rate, basal heat flow, and permeability. An upper limit for recharge to the groundwater flow system is represented by the available infiltration rate. Where the water table coincides with the ground surface, only a portion of the available infiltration is transmitted to the subsurface. The remainder is contributed to surface runoff. The ability of the flow system to transmit the incoming fluid depends upon a variety of factors including topographic relief, permeability, and basal heat flow (Forster and Smith, 1988b). Where the water table lies below the ground surface, the entire available infiltration rate is assumed to be transmitted directly to the water table via one-dimensional flow through an unsaturated zone. Adopting this approach enables us to control the pattern and magnitude of groundwater recharge without specifying, a priori, the position of the water table.

Heat is transferred by both conduction and advection throughout the domains shown in Figure 33. Advective heat transfer above the water table is represented by one-dimensional movement of fluid, in the liquid phase, at a rate determined by the available infiltration rate.

Although values of bulk permeability for the bedrock are likely controlled by the degree of fracturing, we treat both the bedrock and valley fill deposits as equivalent

porous media. Exceptions to this assumption are represented as discrete permeable fracture zones with a homogeneous permeability $k_{f}$ and width $b$ (Figure 33). 
The mathematical model describing the systems shown in Figure 33 is expressed by coupled partial differential equations for heat transfer and fluid flow, by equations

a)
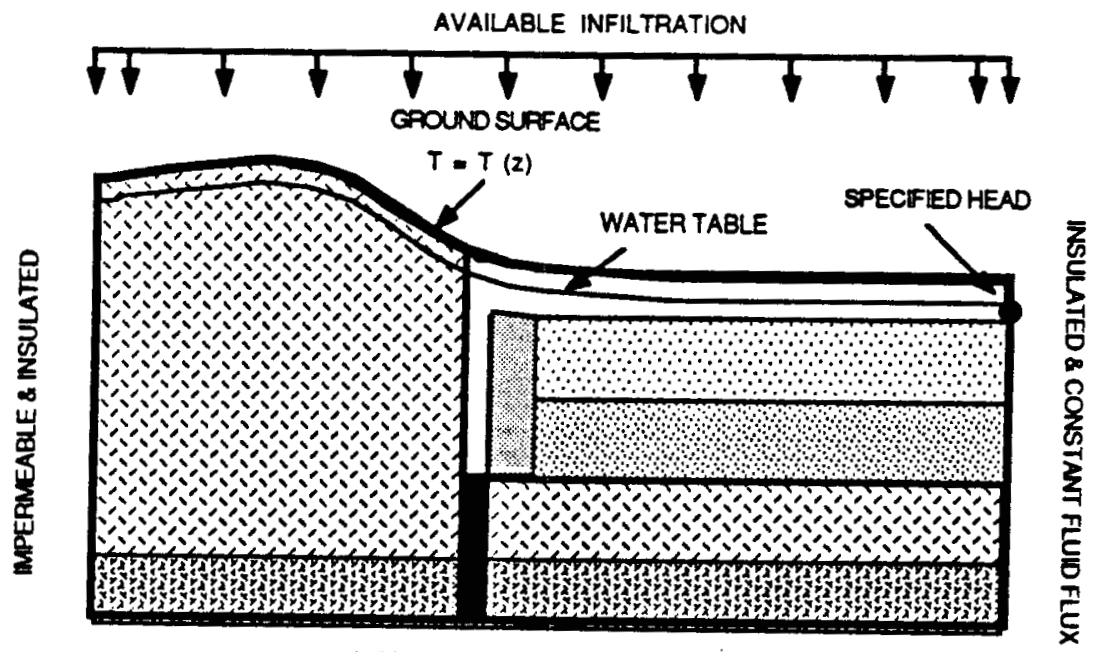

IMPERMEABLE \& UNIFORM HEAT FLUX

\section{BEDROCK}

国 $k=10^{-22} \mathrm{~m}^{2}$

Q $k=10^{-16} \mathrm{~m}^{2}$

b)

\section{VALLEY-FILL ALLUVIUM}

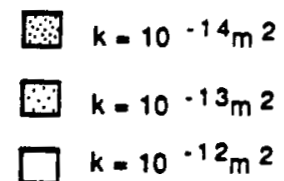
2

$\square k=10^{-12} m^{2}$

FAULT ZONE

$k=10 \cdot 18 \mathrm{~m}^{2}$

W $k=10^{-12} \mathrm{~m}^{2}$

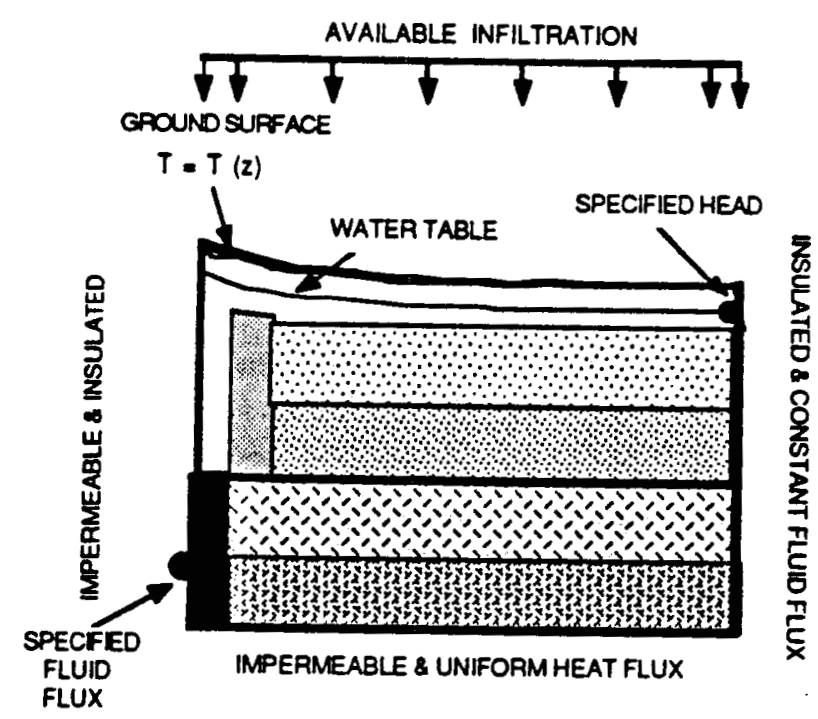

Figure 33. Generalized boundary value problems solved in the modeling study shown with no vertical exaggeration; a) full-length section (18km long) and b) short, local-scale section (8km long). 
of state for the fluid properties, and by boundary conditions for the thermal and fluid flow problems. Details of the mathematical model are outlined by Forster and Smith (1988a). Key assumptions include (1) steady state fluid flow and heat transfer in a saturated porous medium with one-dimensional fluid flow through the unsaturated zone at the available infiltration rate, (2) thermal equilibrium between fluid and solid, (3) the fluid is pure liquid water with density and viscosity a function only of temperature and pressure, (4) the heat capacity and thermal conductivity of the fluid is constant, and (5) porosity, permeability, and thermal conductivity vary in space but not as a function of temperature or pressure.

The equations describing fluid flow and heat transfer are solved using a Galerkin finite element technique. The water table elevation is estimated using an iterative free-surface method that is constrained by the available infiltration rate applied at the ground surface. Two-dimensional vertical sections with planar or radial symmetry are represented by linear triangular elements. Thin high-permeability fracture zones are included by embedding one-dimensional line elements in the field of triangular elements. Details of the computational procedure are given by Forster and Smith (1988a).

\subsubsection{Model Parameterization}

Figure 33 illustrates one of several distributions of permeability used in the modeling effort. In most cases, permeability of the valley-fill alluvium was estimated to range from a minimum of $10^{-14} \mathrm{~m}^{2}$ at the base of the valley-fill to a maximum of $10^{-12} \mathrm{~m}^{2}$ near the ground surface. These estimates are based on the results of pumping tests reported by Mower (1982) and typical values reported in the literature for similar lithologies.

The permeability of the mountain massif was estimated through an iterative modeling approach by solving the full-length boundary value problem (Figure 33a) using the free-surface method to find the position of the water table within the constraints of estimated water table elevations and limits on groundwater recharge rates. The presence of several springs at elevations of $1900 \mathrm{~m}$ ( $400 \mathrm{~m}$ above the valley floor) provides evidence for a water table that is located at relatively high elevations in the mountain massif. Calculated water table elevations were found at high elevations within the model domain when a value of $10^{-16} \mathrm{~m}^{2}$ is assigned for the permeability of the mountain massif and a recharge rate of $1 \mathrm{~mm}$ per year is specified throughout regions elevated above the valley floor. The apparent character of the temperature-depth profiles measured at the valley floor provide an upper limit for direct recharge to the valley fill deposits of $0.3 \mathrm{~mm}$ $y^{1}$. Because the water table elevation depends upon the ratio of recharge rate to permeability, there is a certain degree of uncertainty associated with our estimates. If we assume that recharge rate corresponds to a percentage of the mean annual precipitation in the highlands, it seems reasonable that the mean annual recharge rate falls between 1 to $30 \%$ of annual precipitation. Estimating the mean annual precipitation to be about 
$0.25 \mathrm{~m} \mathrm{y}^{1}$ yields a range in estimated recharge rate of 2.5 to $75 \mathrm{~mm} \mathrm{y}^{1}$. Lower values of recharge are expected at the valley floor where precipitation is reduced below that of the adjacent highlands. Therefore, maintaining the computed water table at the assumed elevation requires a bulk permeability in the range of $10^{-17}$ to $10^{-15} \mathrm{~m}^{2}$. Several runs were made with $\mathrm{k}$ values for the mountain massif ranging from $10^{-17}$ to $10^{-15} \mathrm{~m}^{2}$.

Throughout all simulations, the lower $1 \mathrm{~km}$ of the domain was assigned a permeability of $10^{-22} \mathrm{~m}^{2}$ and the precipitate seal was assigned a value of $10^{-18} \mathrm{~m}^{2}$. Fault zone permeability was assumed to be $10^{-12} \mathrm{~m}^{2}$ and a variety of fault zone widths ranging from 0.1 to $20 \mathrm{~m}(0.33$ to $66 \mathrm{ft})$ were considered in the simulations.

Values of thermal conductivity $(\lambda)$, porosity $(n)$, and specific heat capacity $\left(C_{r}\right)$ were held at the same values in all simulation studies. Although different values of 1 and $n$ were specified in different units shown in Figure $33, C_{r}$ was held constant throughout the model domain. Thermal conductivity of the valley-fill alluvium was assumed to be $1.6 \mathrm{~W} \mathrm{~m}^{-1}{ }^{\circ} \mathrm{C}^{-1}$ and the corresponding porosity was specified as 0.25 . The bedrock units were assigned a uniform value of $2.5 \mathrm{~W} \mathrm{~m}^{-1}{ }^{\circ} \mathrm{C}^{-1}$ for $\lambda$ and 0.05 for $\mathrm{n}$. Thermal conductivity values were selected to be similar to those estimated from our laboratory measurements described in a previous sub-section while porosity values were assumed to be typical of the lithologies present within the modeled domain. Intermediate values of $\lambda=2.0 \mathrm{~W} \mathrm{~m}^{-1} \cdot \mathrm{C}^{-1}$ and $\mathrm{n}=0.1$ were assigned to the precipitate seal, while values of $\lambda=2.5 \mathrm{~W} \mathrm{~m}^{-1}{ }^{\circ} \mathrm{C}^{-1}$ and $\mathrm{n}=0.10$ were assigned to the fault zone.

The fluid is assumed to be pure liquid water with a constant thermal conductivity and specific heat capacity. Fluid density and viscosity are assumed to vary as a function of both temperature and pressure.

\subsubsection{Modelling Results}

The primary goal of the modeling study was to define the groundwater flow system needed to mimic the gross character of the thermal regime observed at Newcastle. Although the regional heat flow and general geometry of the geologic units are known with reasonable certainty, the permeability structure that controls the pattern and rate of groundwater flow is poorly constrained. We modeled a variety of permeability structures by solving both the full-length and short boundary value problems (Figure 33) but were unable to generate the elevated temperatures observed at shallow depths in the valley-fill alluvium. We attribute this difficulty to the inability of the selected model parameters to provide sufficient groundwater heating at depth within the fault zone.

We suspect that our inability to mimic the observed thermal regime was caused, in large part, because modeling a 3-dimensional system with a 2-dimensional approach fails to account for heat transported into the system by components of groundwater flow and conduction heat transfer oriented perpendicular to the plane of the sections shown 
in Figure 33. Although a localized source of elevated heat flow (perhaps a shallow intrusion) could contribute the necessary heat that was unavailable in the modeled flow system, the absence of recent volcanic activity in the area suggests that this is an unlikely explanation. The stable isotope data discussed previously suggests (1) that minimal fractionation has occurred in high-temperature rock-water exchange processes and (2) thermal water sampled in the valley-fill deposits is derived from a meteoric, rather than a plutonic, source. Furthermore, the regional heat flow applied at the base of the modeled domain must be increased by a factor greater than 2 to obtain the required temperatures at shallow depths in the flow system. Good quality heat flow measurements made at a variety of sites in the vicinity of Newcastle (Chapman and others, 1981); however, consistently suggest a regional heat flow in the range of 90 to $110 \mathrm{~mW} \mathrm{~m}^{-2}$. Although testing the relative merits of each of the above explanations requires simulations involving a fully 3-dimensional numerical model, the thermal and permeability data needed to adequately parameterize and constrain such a model are currently unavailable.

Simulations performed by solving the short boundary value problem (Figure 33b), in both planar and radial symmetry modes, provides additional insight. In these simulations a source of heated fluid specified near the base of the fault zone represents the net effect of fluid flow and heat transfer within the mountain massif. A series of radial symmetry runs indicate that highly unrealistic fluid flow rates and temperatures are required to generate a thermal regime akin to that observed at Newcastle. Although more realistic rates could be specified in the planar mode (consistent with the $0.032 \mathrm{~m}^{3}$ $\mathrm{s}^{-1}$ computed on the basis of heat loss calculations) computed temperatures were much lower than observed. Although unable to match the observed thermal regime, we think that fluid discharge to the valley-fill alluvium is best viewed as outflow from a linear source with local variations along the outflow zone, rather than from a single point source. This view is consistent with the results of the resistivity survey that suggests the thermal-chemical plume emanates from a $1.5 \mathrm{~km}(0.9 \mathrm{mi})$ (minimum) region aligned with the mountain front with a localized region of enhanced discharge in the vicinity of the SP anomaly. 


\subsection{DISCUSSION}

We initiated our modelling of fluid flow and heat transport with a working model for the Newcastle hydrothermal system shown in Figure 21. Data collected in this study and further interpretation of existing data has helped us to propose a more refined conceptual model for the hydrothermal system (Figure 34). In this conceptual model a fully 3-dimensional view is adopted.

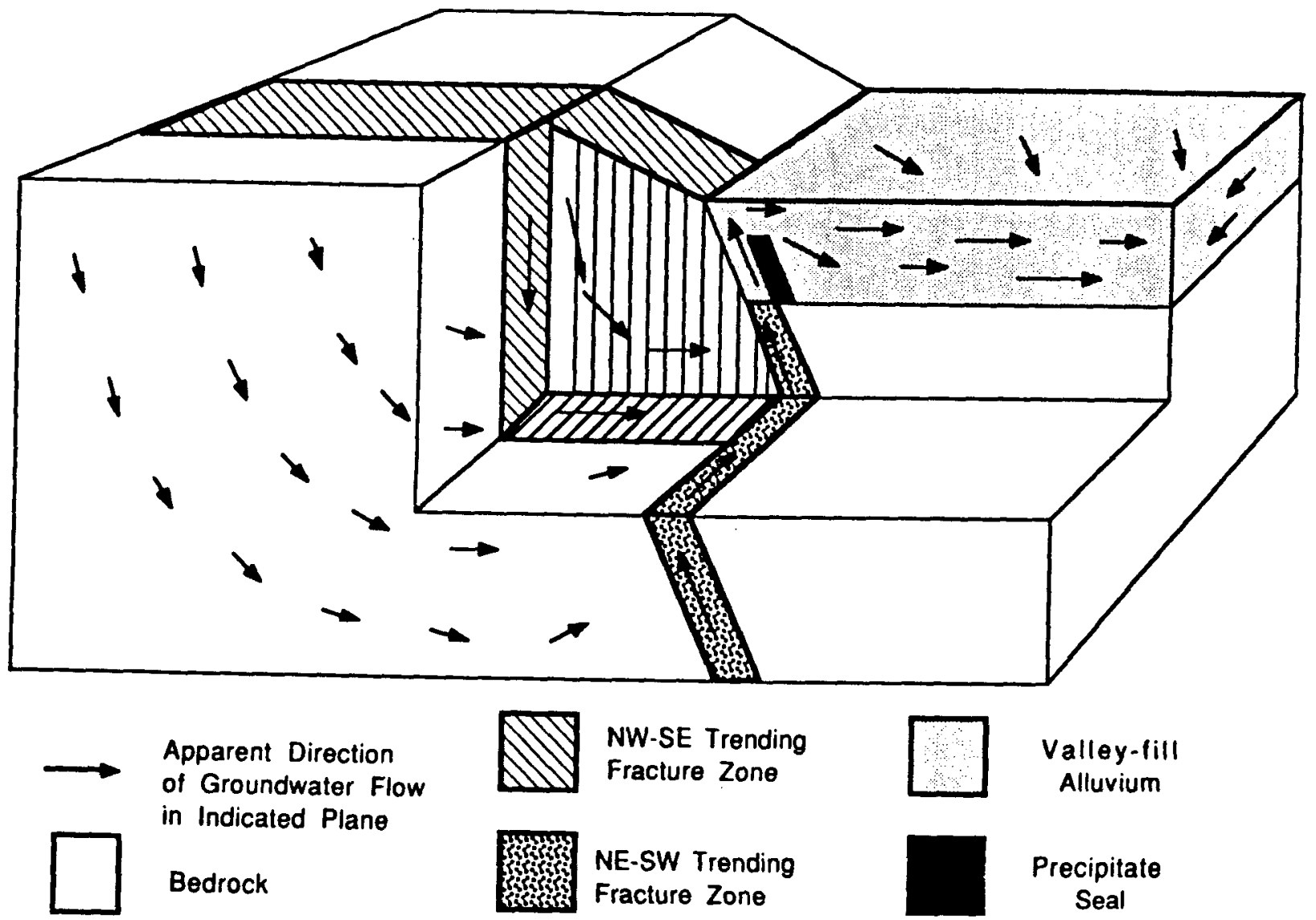

Figure 34. Updated conceptual model Indicating possible patterns of groundwater flow in the Newcastle hydrothermal system.

Inferred patterns of fluid flow are indicated by the apparent directions of flow identified within the various planes shown in Figure 34. Note that, in most cases, the arrows represent only the components of flow within the indicated plane. Topographic relief on the water table is assumed to provide the dominant driving force for fluid flow within the system. Therefore, meteoric water recharged in the highlands circulates deeply within the mountain massif before discharging to the valley-fill sediments. 
The northwest-southeast trend of gravity lows, which may represent a structural zone, and geologic mapping from our study (Section 2) form a critical element of the conceptual model (hatched zone in Figure 34). Enhanced permeability associated with higher density fracturing associated in turn with a high density of faulting in this zone is presumed to provide for active fluid flow and efficient extraction of heat to depths on the order of $5 \mathrm{~km}$ below the valley floor. Because fluid flow in the adjacent lower-permeability protolith is more sluggish, temperatures are likely warmer in the surrounding protolith. As a consequence, additional heat is provided to fluid moving within the fault zone by conductive and advective heat transfer from the protolith to the fault zone. A further focussing of fluid flow and advective heat transport is expected as the Antelope Range fault zone transmits fluid and heat along the fault to the region of lower head located at the intersection of the structures.

Groundwater with elevated temperature and TDS that discharges from the fault zone intersection must mix with cool and relatively fresh groundwater circulating in the valley-fill deposits. This mixing process may contribute to the precipitation of siliceous and/or carbonate minerals within the porous sediments that, in turn, cause a reduction in permeability in the vicinity of the zone of mixing. In early stages of system development, the region of mixing was likely located at the base of the valley-fill sediments. Through time, however, the mixing of fluids in the sediments may contribute to progressive development of a low-permeability seal that extends upwards from the original point of discharge from bedrock to a position relatively close to the ground surface (Figure 34). Concurrent downward movement of the hanging wall block of the Antelope Range fault likely contributed to upward growth of the precipitate seal. Development of a precipitate seal may be enhanced where boiling occurs at the water table.

Heated groundwater discharging to the valley-fill deposits forms a thermal-chemical plume with a size and shape controlled, in large part, by the near-surface groundwater flow system. Previous studies of the groundwater regime near Newcastle (Mower, 1982) indicate a northward trend to the predominant direction of groundwater flow. This interpretation provides the basis for inferring relatively widely spaced heat flow contours when traversing the geothermal system from south to north (see the revised heat flow map shown in Figure 29). Further evidence for an elongate thermal-chemical plume is also provided by the chemistry of groundwater samples WS-1 and 4 (both wells are located near the $500 \mathrm{~mW} \mathrm{~m}^{-2}$ contour in Figure 29. Because both samples WS-1 and 4 were collected at a similar distance from the mountain front (Figure 23), the strong contrast in chemistry between samples WS-1 and 4 suggests that the plume of more heated groundwater discharging to the valley-fill deposits is preferentially moving in a northerly direction away from a source in the vicinity of NC-18 and NC-19.

The conceptual model described here may provide a general model for the character and evolution of blind geothermal systems throughout the Basin and Range 
province. For example, travertine mounds found at the Monroe and Joseph hot springs may represent a later stage in evolution of the class of hydrothermal systems exhibited at Newcastle. Continued upward development of the precipitate seal would be expected to culminate in discharge of the heated fluid at the ground surface and the formation of hot spring controlled mounds. Water level elevations measured in wells completed in the vicinity of the Monroe and Red Hill hot springs indicate a sharp drop in the water table as one moves from the hot springs towards the center of the valley. This strong variation in water table elevation might develop where groundwater movement in the surficial deposits is dammed by the development of a precipitate seal that constrains flow of heated fluid within a well-defined, more permeable, conduit structure. Because monitoring wells drilled on the alluvial fan adjacent to the mountain front failed to penetrate the water table, this feature of the Newcastle system remains unresolved.

Other blind hydrothermal systems at different stages in their development are likely to be found elsewhere in the Basin and Range province. The Newcastle geothermal system is located in one of several regions of elevated groundwater temperature found in the southern portion of the Escalante Desert (Figure 26). Temperatures measured in water wells drilled to a maximum depth of $300 \mathrm{~m}$ (984 ft) indicate that groundwater temperatures exceed the mean annual air temperature of $15^{\circ} \mathrm{C}$ at 4 locations; at Newcastle, $10 \mathrm{~km}(6.2 \mathrm{mi})$ north of Newcastle, $5 \mathrm{~km}(3.1 \mathrm{mi})$ northeast of Beryl, and 15 $\mathrm{km}$ ( $9.3 \mathrm{mi}$ ) southwest of Beryl (Figure 26). Although locally elevated heat flow is indicated near both Newcastle and Beryl (Clement, 1981; Chapman and others, 1981; Rush, 1983), hot springs and other surface indications of a hydrothermal system are lacking at all locations.

Our revised conceptual model for fluid flow and heat transfer at the Newcastle geothermal area provides a framework for confirming current strategies used to explore for blind geothermal systems in the Basin and Range Province. The first step in any exploration program should involve measuring groundwater temperatures in water wells, obtaining electrical conductivity measurements of well water, and collecting water samples for later analyses of major ion concentrations, total dissolved solids, and stable isotope chemistry. Exploration sites should be targeted where linear gravity lows and geologic mapping suggest the intersection of regional-scale faults that may, in turn, indicate regions of enhanced permeability. Electrical geophysical surveys (resistivity and selfpotential) provide an excellent means of delineating thermal-chemical plumes and targeting the probable source of each plume. Shallow thermal monitoring wells (120 to $150 \mathrm{~m}$ deep) strategically placed within the resistivity and S.P. anomalies provide the information needed to assess the overall heat loss from the blind geothermal system and map the details of the shallow thermal regime. Deeper holes (150 to $400 \mathrm{~m}$ deep) are required to collect water samples for isotopic analyses and geothermometry calculations in the region of maximum upflow. Results of studies related to the shallow drilling activities and geophysical surveys, when interpreted within the context of a conceptual 
model of the hydrologic system, yield a solid basis for establishing the worth of drilling a deep exploration well. 


\subsection{CONCLUSIONS}

A detailed conceptual model has been developed to describe the processes of fluid flow and heat transfer in a blind geothermal system found at Newcastle, Utah. A localized fluid upflow zone, identified using shallow heat flow studies and surface geophysical surveys, lies at the intersection of the Antelope Range fault and a $3 \mathrm{~km}(1.9$ mi) wide northwest-trending structural zone with enhanced fracture permeability. In detail, the upflow zone coincides with the intersection of two prominent faults of the structural zone with the Antelope Range fault. Hydrogeochemical evidence, and inferences regarding the character of the subsurface hydrogeologic regime, suggest that heated fluid discharging from the upflow zone to the valley-fill deposits originated as meteoric water recharged in the adjacent Pine Valley Mountains. A thermal-chemical plume mapped in the valley-fill deposits indicates that the that the heated fluid is transported in a northerly direction away from the source in a shallow groundwater flow system. Temperatures measured in shallow wells located directly above the upflow zone indicate a localized region of boiling and a zone where heat transport above the water table may be controlled by free convection of vapor. Although untested, we hypothesize that localization of fluid upflow is caused by the development of a sub-vertical precipitate seal within the valley-fill deposits that prohibits lateral flow. We view the Newcastle geothermal system as having achieved an intermediate stage in an evolutionary sequence that begins with deep discharge of heated fluid at the base of a sediment-filled basin and ends with the development of hot springs located within mounds of siliceous sinter that represent the outcropping of the postulated precipitate seal. We postulate that additional blind geothermal systems may exist, at different stages in this evolutionary process, throughout the Basin and Range province.

The anomalous heat loss from the Newcastle geothermal system is estimated to be 12.4 MW and the corresponding fluid discharge is estimated to be $0.031 \mathrm{~m}^{3} \mathrm{~s}^{-1}$. These revised estimates differ little from those made in previous studies. The new heat flow map provides a more reliable image of the general nature of the shallow hydrothermal system than previous studies.

Temperature-depth data obtained from the Christiansen \#1 exploration well, drilled and logged to a depth of $913 \mathrm{~m}$ (2995 ft) by Union Geothermal, indicates a lower limit to the equilibrium temperature for the geothermal system of $130^{\circ} \mathrm{C}\left(266^{\circ} \mathrm{F}\right)$ encountered in the well at a depth of $100 \mathrm{~m}$. This temperature is slightly higher than equilibrium temperatures computed using chemical geothermometry on analyses of groundwater obtained from shallow wells located within the thermal-chemical plume. At depths greater than $100 \mathrm{~m}$ in $\mathrm{CHR \# 1}$, temperatures fall to a low of $105^{\circ} \mathrm{C}$ before returning to $115^{\circ}$ at the bottom of the drill hole. The roughly isothermal character of the temperature-depth log, at depths in excess of about $200 \mathrm{~m}$, provides additional evidence for the presence of a sub-vertical upflow zone carrying groundwater at a temperature of $130^{\circ} \mathrm{C}$ or greater up-dip along the Antelope Range fault. 


\subsection{RECOMMENDATIONS}

Further studies at Newcastle would help to better understand the character and evolution of blind geothermal systems located throughout the Basin and Range province. Installing additional shallow thermal monitoring wells in the region of maximum heat flow and replacing the collapsed plastic casings in NC-18 and NC-19 with black iron pipe will provide the thermal data needed to characterize the mechanisms of heat transfer operating in the immediate vicinity of the upflow zone and help explain the origin of the strong S.P. anomaly associated with the upflow zone. By completing each well below the water table we would be able to measure the elevation of the water table and collect groundwater samples within the upflow zone. A deep exploration hole should be drilled into the center of the upflow zone, or "throat," to measure the variation of temperature with depth, obtain water samples from the deeper, unstudied part of the system, and test reservoir parameters. Stable isotope and geochemical analyses of the water samples will aid in unravelling the chemical evolution of groundwater during its passage from the highland recharge areas to the thermal-chemical plume found in the adjacent valley-fill deposits.

Central to our conceptual model is the presence of a northwest trending structural zone of enhanced fracture permeability. Additional geologic mapping of the adjacent Pinto (7.5') quadrangle and compilation of new, unpublished mapping in the recharge area of the Newcastle system would allow us to check our conceptual model against the regional distribution of mappable faults. One goal of this mapping would be to establish the integrity of the structural zone as it is traced into the recharge area. Another goal would be to search for evidence concerning the origin and character of this zone. Additional detailed gravity profiles along northeast-southwest trends could also be made to help strengthen the evidence for the northwest trending structural zone.

Several recently developed techniques are available for quantifying the hydraulic conductivity of fractured rocks. Some of these techniques could be applied to the Newcastle area to better understand the "enhanced permeability" of the northwesttrending structural zone presented in the conceptual model. In particular, detailed measurements of fracture orientations and aperture widths could be measured from several sites both within and outside of the structural zone to better characterize permeability variations of our conceptual model.

Finally, we recommend a regional-scale review of existing groundwater temperature and chemistry information to test our hypothesis that similar fault-controlled geothermal systems may be found, at different stages in their evolution, throughout the Basin and Range province and to identify promising locations to explore for previously unidentified blind geothermal systems. 


\subsection{REFERENCES}

Anderson, J.J., and Kurlich, R.A., 1989, Post-Claron Formation, pre-regional ash-flow tuff early Tertiary stratigraphy of the southern High Plateaus of Utah: Geological Society of America Abstracts with Programs, v. 21, no. 5, 50 p.

Anderson, R.E., 1987, Neogene geologic history of the Nevada-Utah border area at and near latitude $37^{\circ} 30^{\prime}$ N.: Geological Society of America Abstracts with Programs, v. 19 , no. 7 , p. 572 .

Anderson, R.E., and Christenson, G.E., 1989, Quaternary faults, folds, and selected volcanic features, Cedar City $1^{\circ} \times 2^{\circ}$ quadrangle, Utah: Utah Geological and Mineral Survey Miscellaneous Publication, in press, scale 1:250,000.

Angelier, Jacques, 1979, Determination of the mean principal directions of stress for a given fault population: Tectonophysics, v. 156, p. T17-T26.

Angelier, Jacques, 1984, Tectonic analysis of fault slip data sets: Journal of Geophysical Research, v. 89 , no. B7, p. 5835-5848.

Angelier, Jacques, Colletta, Bernard, and Anderson, R.E., 1985, Neogene paleostress changes in the Basin and Range: A case study at Hoover Dam, Nevada-Arizona: Geological Society of America Bulletin, v. 96, p. 347-361.

Axen, G.J., and Wernicke, B.P., 1987, Magnitude and Style of Miocene upper-crustal extension in the southern Nevada area: Geological Society of America Abstracts with Programs, v. 19, no. 7, p. 576.

Best, M.G., 1987, Geologic map and sections of the area between Hamblin Valley and Escalante Desert, Iron County, Utah: U.S. Geological Survey Map I-1774, scale $1: 50,000$.

Best, M.G., Christiansen, E.H., Blank, R.H. Jr., 1990, Oligocene caldera complex and calcalkaline tuffs and lavas of the Indian Peak volcaric field, Nevada and Utah: Geological Society of America Bulletin, v. 101, p. 1076-1090.

Blackett, R.E, Shubat, M.A., Chapman, D.S., Forster, C.B., and Schlinger, C.M., 1989, An assessment of geothermal resources at Newcastle, Utah: Geothermal Resources Council, Transactions, v. 13, p. 109-116.

Bodvarsson, G., 1973, Temperature inversions in geothermal systems: Geoexploration, v. 11, p. 141-149. 
Cady, J.W., 1980, Calculation of gravity and magnetic anomalies of finite-length right polygonal prisms: Geophysics, v. 45, p. 1507-1512.

Capuano, R.M., and Bamford, R.W., 1978, Initial investigation of soil mercury geochemistry as an aid to drill site selection in geothermal systems: Earth Science Laboratory, University of Utah Research Institute Report ID0/78-1701.b.3.3, ESL$13,32 \mathrm{p}$.

Celerier, Bernard, 1988, How much does slip on a reactivated fault plane constrain the stress tensor?: Tectonics, v. 7, no. 6, p. 1257-1278.

Chapman, D.S., Clement, M.D., and Mase, C.W., 1981, Thermal regime of the Escalante Desert, Utah, with an analysis of the Newcastle geothermal system: Journal of Geophysical Research, v. 86, no. B12, p. 11,735-11,746.

Chisholm, T.J., and Robertson, J.A., 1988, Precision gravity survey of the Newcastle geothermal system in Iron county, Utah, University of Utah unpublished report.

Clement, M., 1981. Heat Flow and Geothermal Assessment of the Escalante Desert, Part of the Oligocene to Miocene Volcanic Belt in Southwestern Utah: University of Utah, Dept. of Geology and Geophysics, M.S. Thesis, 118 p.

Cook, K.L., Nilsen, T.H. and Lambert, J.F., 1971, Gravity base station network in Utah - 1967: Utah Geological and Mineral Survey Bulletin 92, 57 p.

Dansgaard, W., 1964. Stable isotopes in precipitation: Tesslus, v. 16, p. 436-468.

Denton, E.H., 1976, Helium sniffer test, Newcastle, Utah 10-26 March 1976: U.S. Geological Survey Open-File Rept. 76-421, 4 p.

Dobrin, M.B. and Savit, C.H., 1988, Introduction to Geophysical Prospecting: McGrawHill Book Company, New York City, 867 p.

Eaton, G.P., Wahl, R.R., Prostka, H.J., Mabey, D.R. and Kleinkopf, M.D., 1978, Regional gravity and tectonic patterns: Their relationship to late Cenozoic epeirogeny and lateral spreading in the western Cordillera, in: Smith, R.B. and Eaton, G.P., eds., Cenozoic tectonics and regional geophysics of the western Cordillera: Geological Society of America Memoir 152, p. 51-91.

Forster, C.B., and L. Smith, 1988a, Groundwater flow systems in mountainous terrain, 1, Numerical modelling technique, Water Resources Research, v. 24 no. 7, p. 9991010. 
Forster, C.B., and L. Smith, 1988b, Groundwater flow systems in mountainous terrain, 2, Controlling factors, Water Resources Research, v. 24 no. 7, p. 1011-1023.

Fouillac, C., and G. Michard, 1981. Sodium/lithium ratio in water applied to the geothermometry of geothermal waters: Geothermics, v. 10, p. 55-70.

Fournier, R.O., 1981. Application of water geochemistry to geothermal exploration and reservoir engineering: in Geothermal Systems: Principles and Case Histories, (L. Rybach and L.J.P. Muffler, eds.),John Wiley, New York, p. 109-143.

Foumier, R.O., and A.H. Truesdell, 1973. An empirical Na-K-Ca geothermometer for natural waters: Geochimica et Cosmochimica Acta, v. 37, p. 1255-1275.

Freeze, R.A, and Cherry, J.A., 1979, Groundwater: Prentice-Hall, Inc., Englewood Cliffs, N.J., 604 p.

Giggenbach, W.F., 1988. Geothermal solute equilibria -- Derivation of Na-K-Mg-Ca geoindicators: Geochimica et Cosmochimica Acta, v. 52, p. 2749-2765.

Godson, R.H., 1978, Program BOUGUER: U.S. Geological Survey internal document (modified 4/1981), Menlo Park, California, 15 p.

Grant, S.K., and Proctor, P.D., 1988, Geology of the Antelope Peak quadrangle, Iron County, Utah: Utah Geological and Mineral Survey Open File Report No. 130, 1 pl. $1: 24,000,32 \mathrm{p}$.

Hoover, D.B., and Pierce, H.A., 1987, Audio-magnetotelluric data release for the Newcastle, Utah geothermal area: U.S. Geol. Survey Open-File Report 87-69, 6 p.

Jensen, M.L., and Qidwai, Hayat, no date, Surface evidence of geothermal sites by mercury soil-gas collecting: Utah Geological and Mineral Survey, unpublished report, $24 \mathrm{p}$.

Klauk, R.H., and Gourley, C., 1983, Geothermal assessment of a portion of the Escalante Valley, Utah: Utah Geological and Mineral Survey Special Studies 63, 57 p.

Klusman, R.W., and Landress, R.A., 1978, Secondary controls on mercury in soils of geothermal areas: Journal of Geochemical Exploration, v.9, p. 75-91.

Lachenbruch, A.H., and Sass, J.H., 1978, Models of an extending lithosphere and heat flow in the Basin and Range province: in Cenozoic Tectonics and Regional Geophysics of the Western Cordillera, Mem. Geol. Soc. Am., 152, p. 209-250. 
Lachenbruch, A.H., Sorey, M.L., Lewis, R.E., and Sass, J.H., 1976, The near-surface hydrothermal regime of Long Valley Caldera: Jour. Geophys. Research, v. 81, no. 5, p. 763-768.

Mase, C.W., Chapman, D.S. and Ward, S.H., 1978, Geophysical study of the Monroe - Red Hill geothermal system: Topical Report EY-76-S-07-1601, Univ. of Utah, Salt Lake City, Utah, 89 pp.

Mase, C.W., Galanis, S.P. Jr., and Munroe, R.J., 1979, Near-surface heat flow in Saline Valley, California: U.S. Geological Survey Open-File Report, 79-1136.

Mabey, D.R., and Budding, K.E., 1987, High-temperature geothermal resources of Utah: Utah Geological and Mineral Survey Bulletin 123, 64 p.

Mower, R.W., 1982. Hydrology of the Beryl-Enterprise Area, Escalante Desert, Utah, With Emphasis on Ground Water. State of Utah, Dept. of Natural Resources, Tech. Publ. 73.

Muffler, L.J.P., 1979, Summary [of geothermal resources of the U.S.], Table 20, p. 157, in Muffler, L.J.P. (ed.), Assessment of geothermal resources of the United States - 1978: U.S. Geological Survey Circular 790, 163 p.

Nielson, D.L., 1978, Radon emanometry as a geothermal exploration technique; theory and an example from Roosevelt Hot Springs KGRA: Earth Science Laboratory, University of Utah Research Institute, U.S. Department of Energy report IDO/781701.b.1.1.2, ESL-14, 31p.

Parasnis, D.S., 1971, Temperature extrapolation to infinite time in geothermal measurements: Geophysical Prospecting, V. 19, p. 612-614.

Parry, W.T., Benson, N.L., and Miller, C.D., 1976, Geochemistry and hydrothermal alteration at selected Utah hot springs, Final Report: University of Utah, Dept. of Geology and Geophysics, National Science Foundation contract GI-43741, 131 p.

Pe, W., 1980, Gravity survey of the Escalante Desert and vicinity in Iron and Washington Counties, Utah: University of Utah, Dept. of Geology and Geophysics, M.S. thesis, Salt Lake City, Utah, $151 \mathrm{p}$.

Pe, Win, and Cook, K.L., 1980, Gravity survey of the Escalante Desert and Vicinity, in Iron and Washington Counties, Utah: Earth Science Laboratory/University of Utah Research Institute Rept. no. DOE/ID/12079-14, 169 p. 
Petit, J.P., 1987, Criteria for the sense of movement on fault surfaces in brittle rocks: Journal of Structural Geology, v. 9, no. 5/6, p. 597-608.

Plouff, D., 1977, Preliminary documentation for a FORTRAN program to computer gravity terrain corrections based on topography digitized on a geographic grid, U.S. Geological Survey, Open File Report 77-535, 45 p.

Press, W.H., Flannery, B.P., Teukolsky, S.A., Vetterling, W.T., 1986, Numerical recipes - The art of scientific computing: Cambridge University Press, Cambridge, 780 p.

Reches, Ze'ev, 1987, Determination of the tectonic stress tensor from slip along faults that obey the Coulomb yield condition: Tectonics, v. 6, no. 6, p. 849-861.

Robertson, J.A., The gravity method and its application at Newcastle, Utah, unpublished report.

Ross, H.P., Blackett, R.E., Shubat, M.A., and Mackelprang, C.E., (in prep.), Delineation of thermal upflow and outflow plume with electrical resistivity and self-potential data -- Newcastle geothermal area, Utah (paper submitted to Geothermal Resources Council, March 1990).

Ross, H.P., and Moore, J.N., 1985, Geophysical investigations of the Cove FortSulphurdale geothermal system, Utah: Geophysics, v. 50, no. 11, p. 1732-1745.

Ross, H.P., Nielson, D.L., and Moore, J.N., 1982, Roosevelt Hot Springs geothermal system, Utah -- case study: American Association of Petroleum Geologists Bulletin, v. 66 , no. 7 , p. $879-902$.

Rowley, P.D., and Siders, M.A., 1988, Miocene calderas of the Caliente Caldera complex, Nevada-Utah: EOS, v. 69, no. 44, p. 1508.

Rowley, P.D., Steven, T.A., Anderson, J.J., and Cunningham, C.G., 1979, Cenozoic stratigraphic and structural framework of southwestern Utah: U.S. Geological Survey Professional Paper 1149, 22 p.

Rupert, J., 1988, A gravitational terrain correction program for IBM compatible personal computers: Geological Survey of Canada, Open File Report 1834, Ottawa, Canada, $20 \mathrm{pp}$.

Rush, F.E., 1977, Subsurface-temperature data for some wells in western Utah:

U.S. Geological Survey Open-File Rept. 77-132, 36p. 
Rush, F.E., 1983, Reconnaissance of the hydrothermal resources of Utah: U.S. Geol. Survey Professional Paper 1044-H, p. H1-H49.

Sass, J.H., and Sammel, E.A., 1976, Heat flow data and their relation to observed geothermal phenomena near Klamath Falls, Oregon, Journal of Geophysical Research, v. 81, p. $4863-4868$.

Shubat, M.A., and Siders, M.A., 1988, Geologic map of the Silver Peak quadrangle, Iron County, Utah: Utah Geological and Mineral Survey Map 108, 13 p., scale $1: 24,000$.

Siders, M.A., 1985, Geologic map of the Beryl Junction quadrangle, Iron County, Utah, Utah Geological and Mineral Survey Map 85, 11 p., scale 1:24,000.

Siders, M.A., Geologic map of the Mount Escalante quadrangle, Iron County, Utah: Utah Geological and Mineral Survey Map, in press.

Siders, M.A., Rowley, P.D., Shubat, M.A., Christenson, G.E., and Galyardt, G.L., 1989, Geologic map of the Newcastle quadrangle, Iron County, Utah: U.S. Geological Survey Open-File Report 89-449, scale 1:24,000.

Smith, R.B., and Sbar, M.L., 1974, Contemporary tectonics and seismicity of the western United States with emphasis on the Intermountain Seismic Belt: Geological Society of America Bulletin, v. 85, p. 1205-1218.

Sorey, M.L., Lewis, R.E. Olmstead, F.H., 1978, The hydrothermal system of Long Valley Caldera, California, U.S. Geological Survey Professional Paper, 1044-A, 60 p.

Telford, W.M., Geldart, L.P., Sheriff, R.E. and Keys, D.A., 1976, Applied Geophysics: Cambridge University Press, Cambridge, Great Britain, 860 p.

Weissberg, B.G., Browne, R.L., and Seward, T.M., 1979, Ore metals in active geothermal systems in Geochemistry of hydrothermal ore deposits, Barnes, H.L., ed., John Wiley and Sons, New York, pp. 738-780.

Wernicke, B.P., Snow, J.K., Axen, G.J., Burchfiel, B.C., Hodges, K.V., Walker, J.D., and Guth, P.L., 1989, Extensional tectonics in the Basin and Range province between the southern Sierra Nevada and the Colorado Plateau: 28th International Geological Congress Field Trip Guidebook T138, American Geophysical Union, 80 p.

Williams, P.L., 1967, Stratigraphy and petrology of the Quichapa Group, southwestern Utah and southeastern Nevada: Seattle, University of Washington, unpublished Ph.D. dissertation, $139 \mathrm{p}$. 
Zoback, M.L., Anderson, R.E., and Thompson, G.A., 1981, Cainozoic evolution of the state of stress and style of tectonism of the Basin and Range province of the western united States: Phil. Trans. R. Soc. Lond. A 300, p. 407-434. 


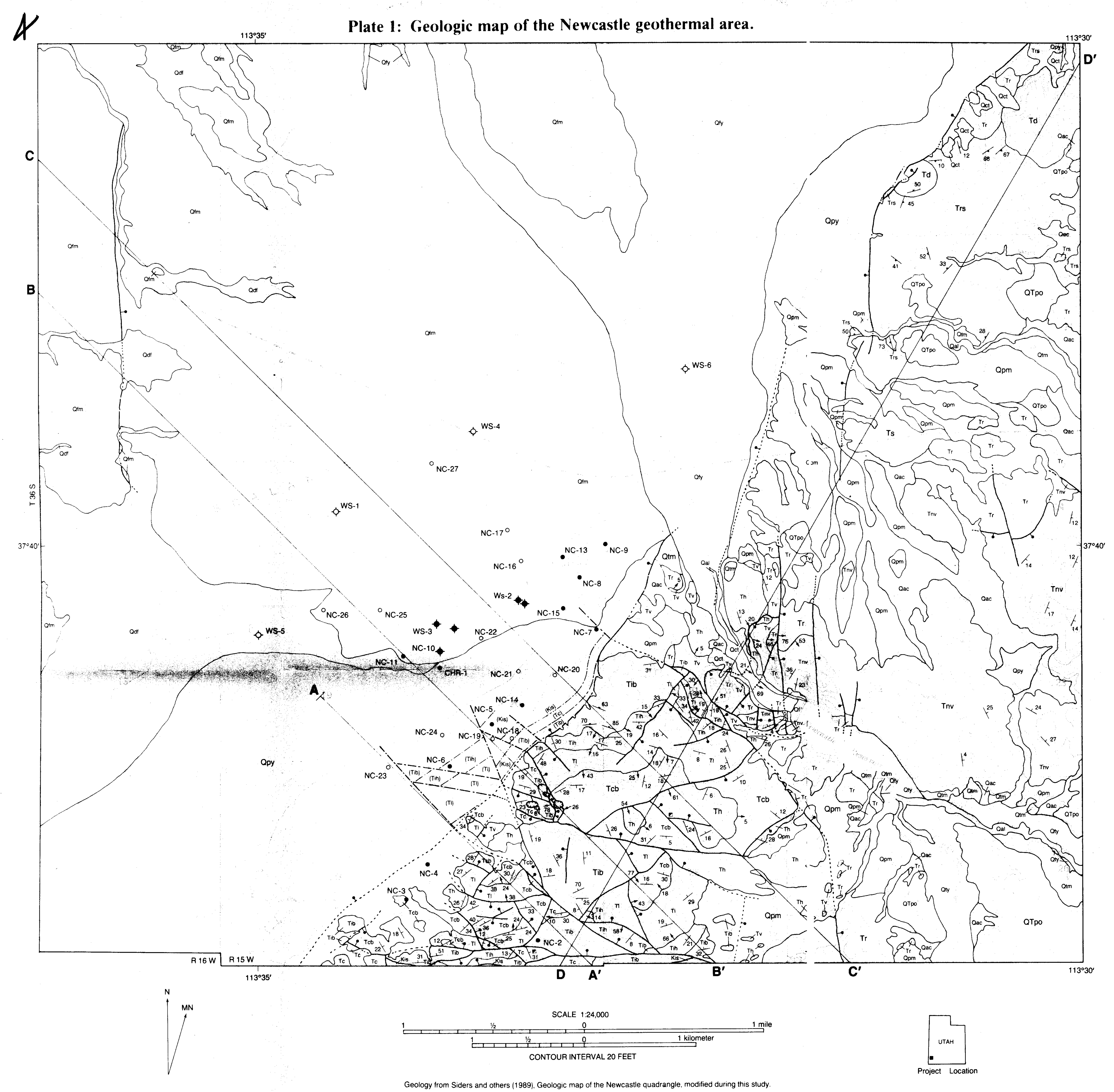


Plate 2. Geologic cross sections A-A; B-B , C-C"
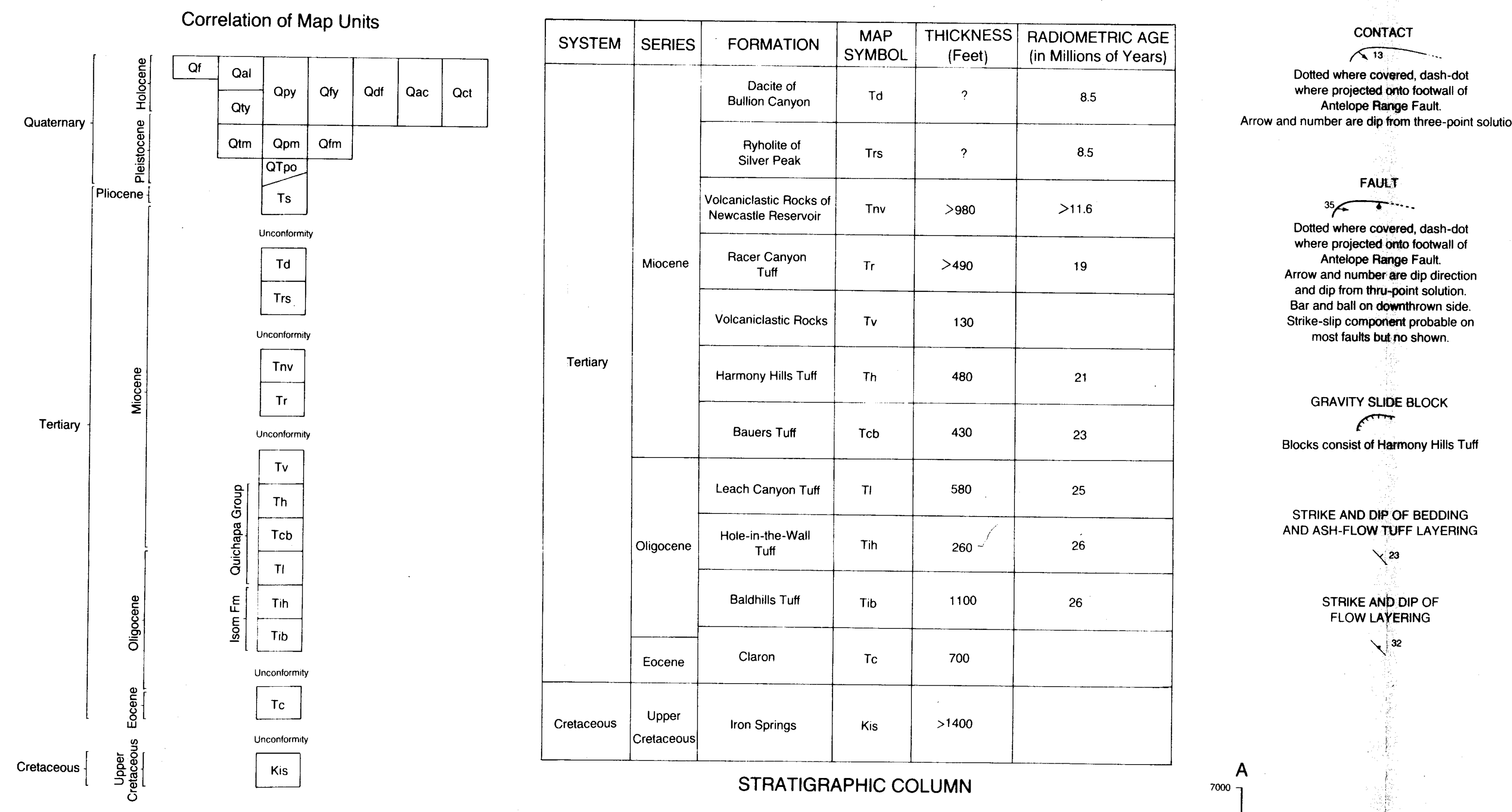

LITHOLOGY OF FOOTWALL
OF ANTELOPE RANGE FAULT

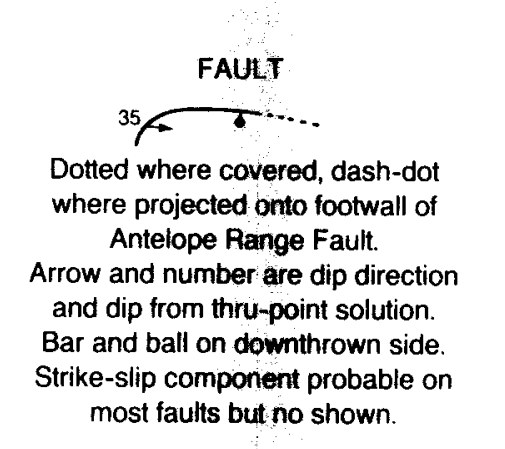

PROSPECT

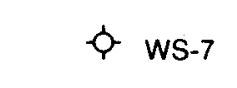

GEOTHERMAL WELL

${ }_{\mathrm{NC}-28}$

GRAVITY SLIDE BLOCK

IRRIGATION WELL

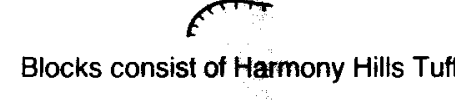

$\phi$

STRIEE AND DIP OF BEDDING
AND ASH-FLOW TUFF LAYERING

$Y^{23}$

-

STRIKE ANDD DP OF
FLOW LAYERING

○

BRECCIA

$\therefore \because{ }^{\circ}$

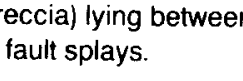

STRATIGRAPHIC COLUMN

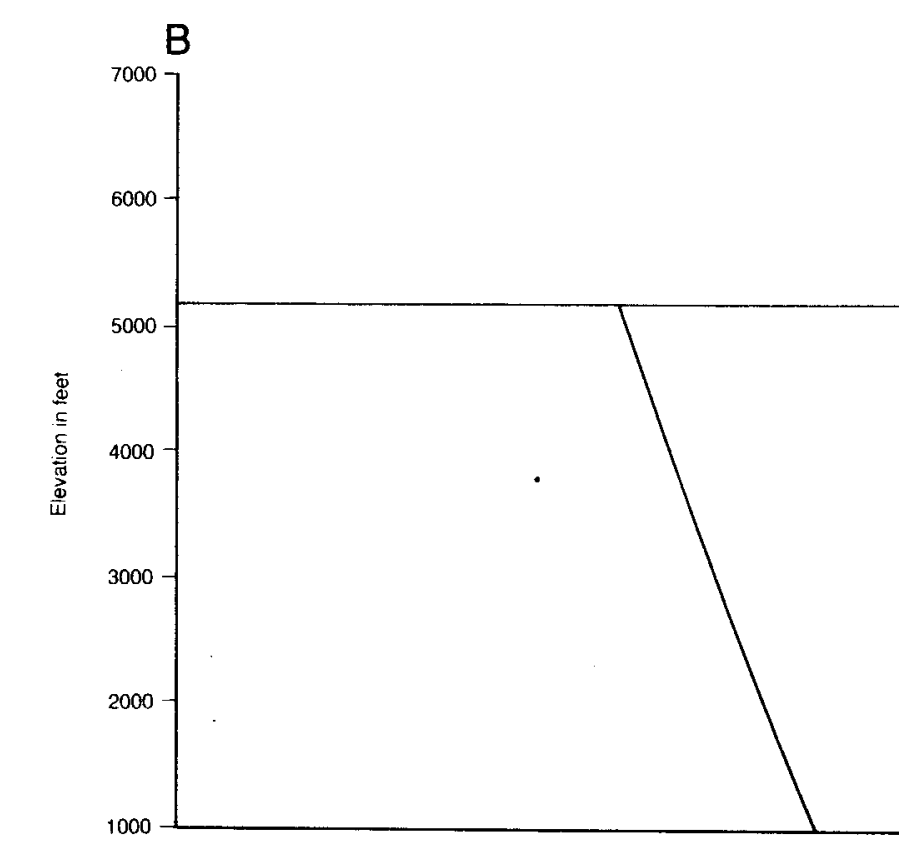

$Q d y+Q f m+Q T p o+T s$
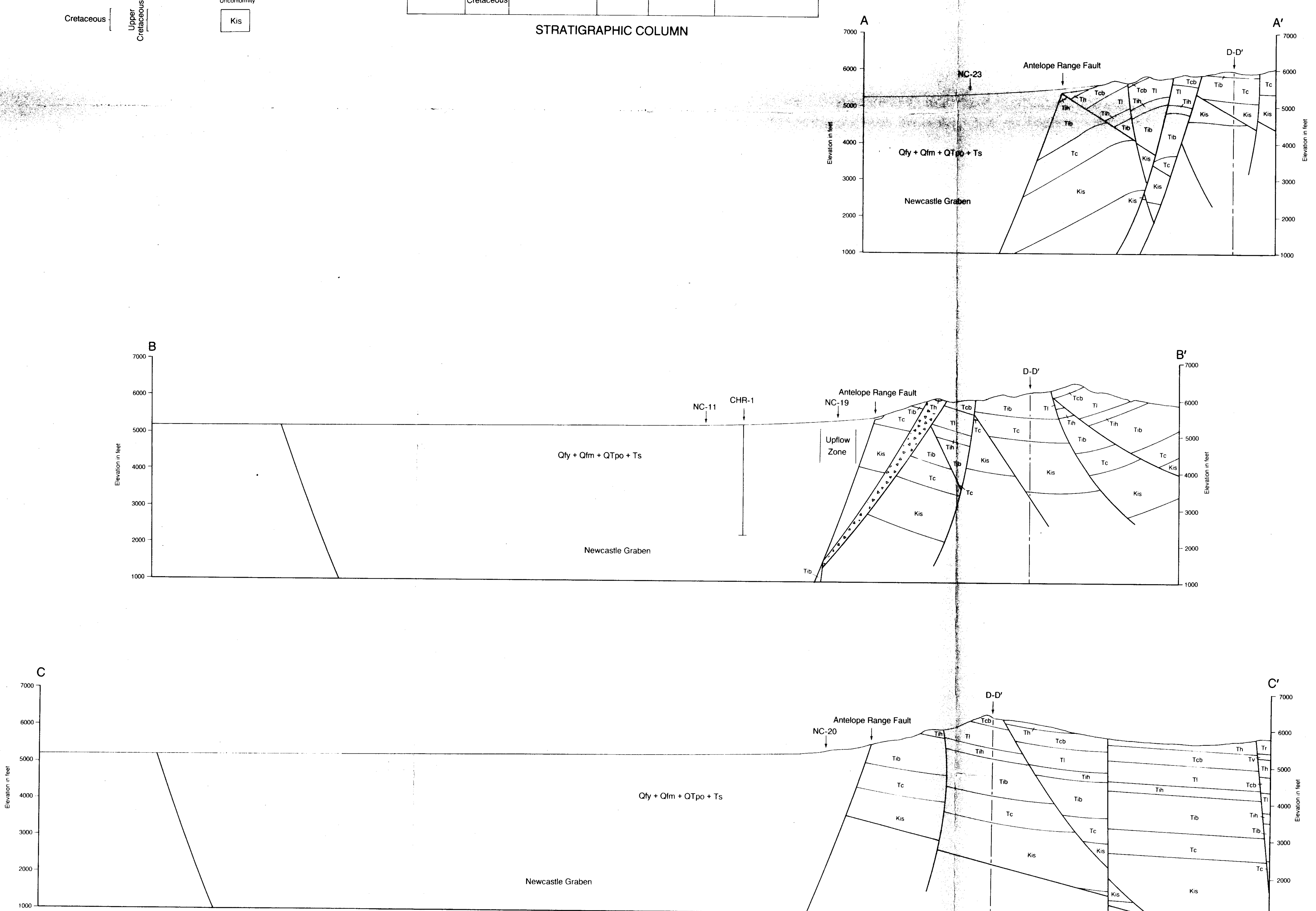

$Q d y+Q l m+Q T p o+T s$

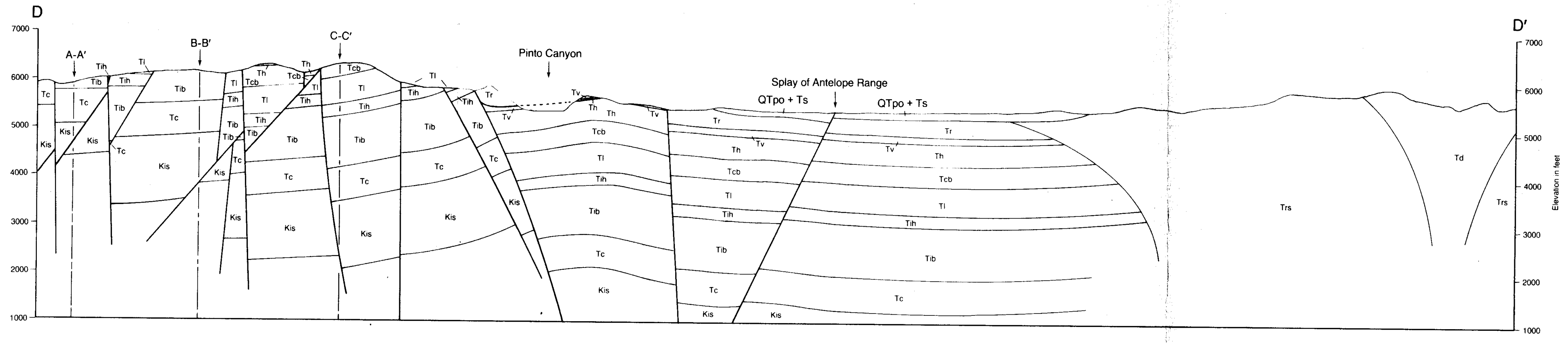

